National Wetlands Inventory

MARCH 1984

\title{
Wetlands of the United States: Current Status and Recent Trends
}

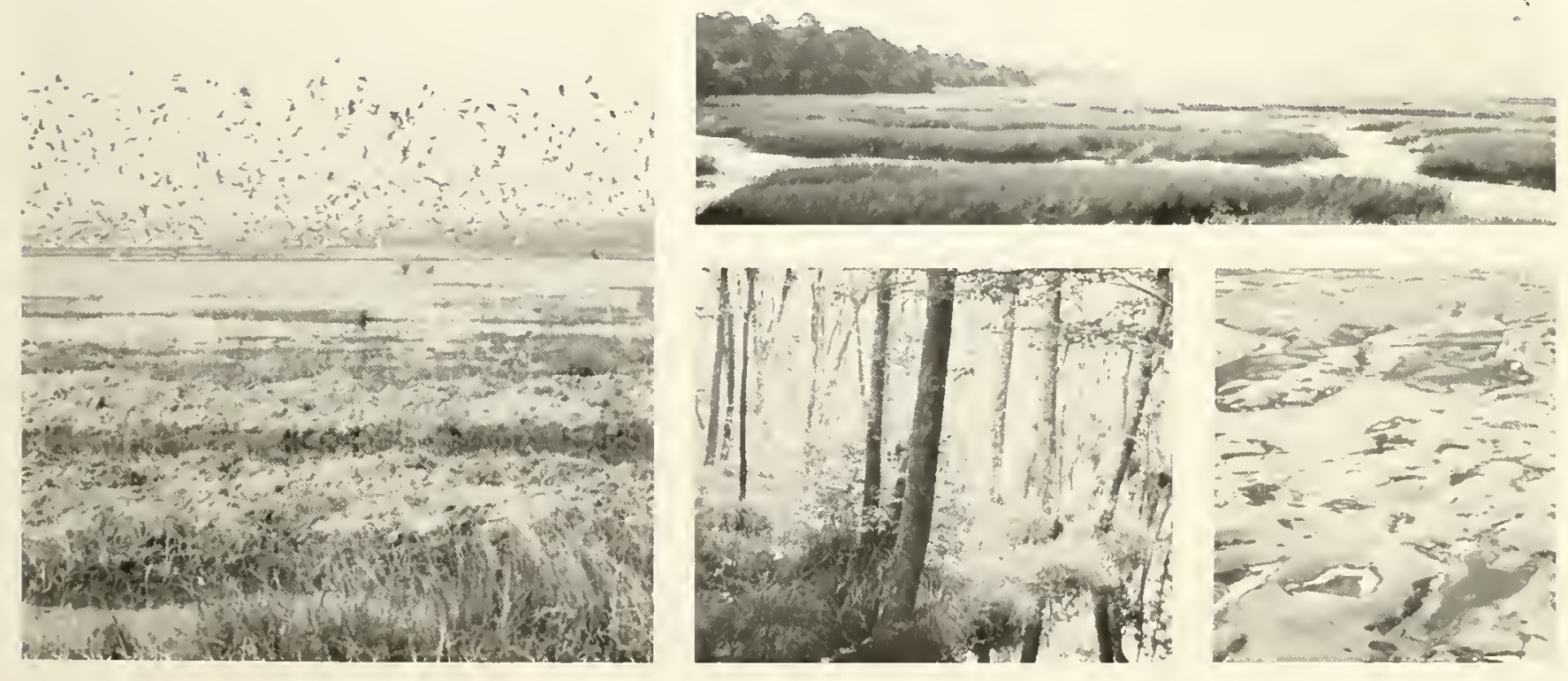

\section{U.S. Department of the Interior}


Photos on Cover By: Ackerknecht, Childers, Tiner, USFWS 
WETLANDS OF THE UNITED STATES:

CURRENT STATUS AND RECENT TRENDS

by

Ralph W. Tiner, Jr.

U.S. Fish and Wildlife Service

Habitat Resources

One Gateway Center

Newton Corner, Massachusetts 02158

MARCH 1984

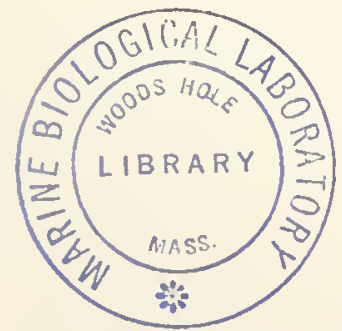

For sale by the Superintendent of mocuments, U.S. Government Printing OHce, Washington, D.: 20402 



\section{Acknowledgements}

Many people have contributed to this report. The entire Service Directorate has reviewed the draft manuscript. Particular thanks are extended to the following individuals for their assistance in providing information and comments: David Almand (AP-WO). Ralph Andrews (HR-R5), Richard Bishop (Iowa Conservation Commission), Joe Carroll (HR-R4), Tony Davis (HR-R5), Clifford Day (HR-R5), Richard Eichhorn (RE-WO), Chuck Elliott (HR-R6), Ron Erickson (HR-R3), David Fruge (HR-R4), Warren Hagenbuck (HR-R2), Jon Hall (HR-R7), Ben Harrison (HR-R1), John Hefner (HR-R4), Ken Huntington (HRR6), William Krohn (DBS-WO), William Mangun (AP-WO), Phil Morgan (FR-R4). Chuck Mullins (HR-R2), Bob Noffsinger (HR-R4), John Organ (WR-R5), Dennis Peters (HR-RI), Richard Pospahala (MBM-L), Mark Schaffer (MBM-WO), Robert Smith (MBM-WO), Ronald Reynolds (MBM-L), Edwin Verburg (AP-WO), Larry Vinzant (HRR4), Rolf Wallenstrom (DAHR) and Bill Zinni (HR-R5). Art work was prepared by Sonya Harris (NWI-WO). Manuscript typing and proofreading were done by Lois Cohen, Marguerite Donnelly, Alicia Marotta, Lynne Ricci (HR-R5), Suzanne Melancon (HR-WO). and Connie Walker (HR-WO). Special credit is due to Bill Wilen. National Coordinator. Wetlands Inventory, for his advice, criticism, and support during the entire scope of this report's preparation. 


\section{Table of Contents}

Table of Contents .

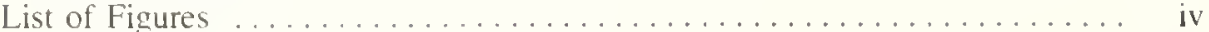

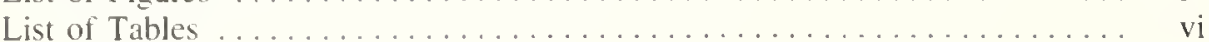

Executive Summary ........................... vii

Introduction ................................... I

What Is A Wetland?............................... 2

The Fish and Wildlife Service's Definition .................. 2

References................................. 3

Major Wetland Types of the United States .................. 5

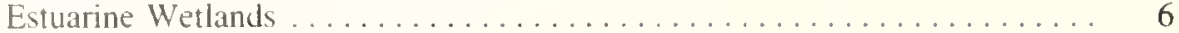

Estuarine Emergent Wetlands....................... 6

Estuarine Intertidal Flats . . . . . . . . . . . . . . . . . . . . . 6

Estuarine Scrub-Shrub Wetlands. . . . . . . . . . . . . . . . . 8

Palustrine Wetlands................................. 9

Palustrine Emergent Wetlands. ....................... 9

Palustrine Scrub-Shrub Wetlands . . . . . . . . . . . . . . . . . . . 11

Palustrine Forested Wetlands ....................... II

References .................................. 11

Why Are Wetlands Important?......................... 13

Fish and Wildlife Values........................... 13

Fish and Shellfish IIabitat....................... 13

Waterfowl and Other Bird Habitat .................... 14

Furbearer and Other Wildlife Habitat................... 16

Environmental Quality Values .................... 18

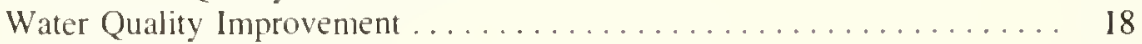

Aquatic Productivity ............................. I9

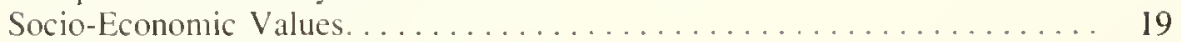

Flood and Storm Damage Protection .................... 2I

Erosion Control ................................. 23

Water Supply and Groundwater Recharge . . . . . . . . . . . . . . . 23

Harvest of Natural Products . . . . . . . . . . . . . . . . . . . . . . . 23

Recreation and Aesthetics.......................... 24 


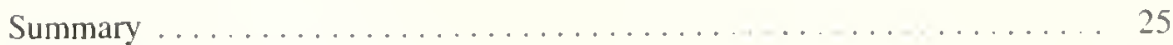

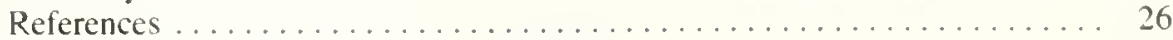

Current Status and Trends of U.S. Wetlands. . . . . . . . . . . . . 28

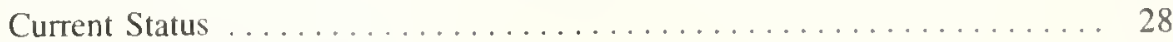

Forces Changing Wetlands ........................ 30

Recent National Wetland Trends . . . . . . . . . . . . . . 30

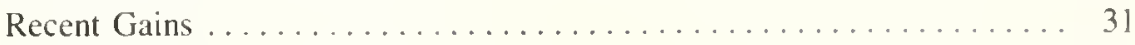

Recent Losses ............................... 31

Regional Historical Perspective. ...................... 32

Current Regional Development Pressures................. 33

National Problem Areas ............................ 35

Estuarine Wetlands of the U.S. Coastal Zone ................. 36

Louisiana's Coastal Marshes.............................. 37

Chesapeake Bay's Submerged Aquatic Beds . . . . . . . . . . . . . . . . 39

South Florida's Palustrine Wetlands.................... 40

Prairie Pothole Region's Emergent Wetlands................ 42

Wetlands of Nebraska's Sandhills and Rainwater Basin ............ 46

Forested Wetlands of the Lower Mississippi Alluvial Plain . . . . . . . . . 48

North Carolina's Pocosins. . . . . . . . . . . . . . . . . . . . . . . . 49

Western Riparian Wetlands........................ 50

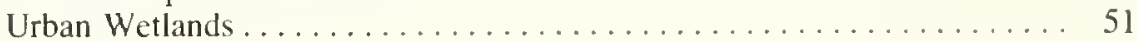

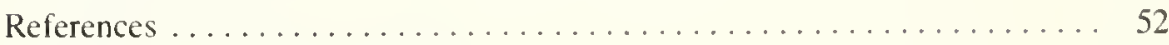

The Future of America's Wetlands. ..................... 54

Management Recommendations ..................... 56

References .................................... 57

Appendix A. Glossary of Common and Scientific Names of

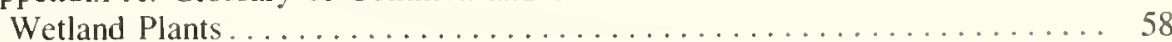




\section{List of Figures}

No.

l Schematic diagram showing wetlands, deepwater habitats, and uplands on

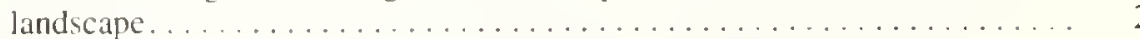

2 The Fish and Wildlife Service's of ficial wetland classification report.......

3 Classification hierarchy of wetlands and deepwater habitats, showing

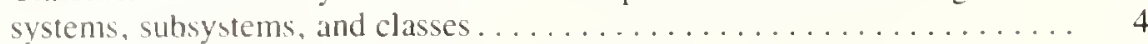

4 Diagram showing major wetland and deepwater habitat systems .......

5 Examples of estuarine emergent wetlands . . . . . . . . . . . . . . .

6 Cross-section of a Northeastern salt marsh . . . . . . . . . . . . . . .

7 Examples of estuarine intertidal flats . . . . . . . . . . . . . . . . .

8 Mangrove-dominated estuarine scrub-shrub wetlands of Florida. . . . . . . . .

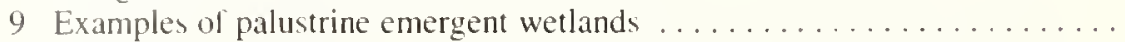

10 Generalized vegetation zones of a pothole wetland in relattionship to water

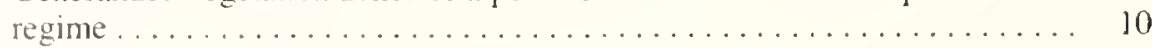

1] Examples of palustrine scrub-shrub wetlands................ 11

12 Examples of palustrine forested wetlands ................. 12

13 Wetland habitat utilization by several families of birds . . . . . . . . 14

14 Migratory birds using wetlands . . . . . . . . . . . . . . . 15

15 Waterfowl habitat areas of major national concern ............ 16

16 Wetlands are important to many other wildlife species............ 17

17 Aerial view of Tinicum Marsh near Philadelphia, Pennsylvania. . . . . . . . . 19

18 Relative productivity of wetland ecosystems in relation to others....... 20

19 Simplified food pathways from estuarine wetland vegetation to commercial and recreational fishes. . . . . . . . . . . . . . . . . . 20

20 Wetland value in reducing llood crests and flow rates after rainstorms..... 21

21 Wetland drainage and filling increase the potential for damaging floods .... 22

22 Estuarine-dependent fish, like salmon, provide the majority of the commercial fisheries in the United States................... 24

23 Wetlands provide opportunities for recreational fishing............ 25

24 Many Americans enjoy watching birds in and around wetlands ......... 25

25 Relative abundance of wetlands in the U.S. (1984)............... 28

26 Extent of wetlands in the conterminous U.S. in the mid-1970's . . . . . . . 29

27 Original and remaining acreages of wetlands in the conterminous U.S. . . . 29

28 Net losses and gains in wetlands of the conterminous U.S. between the mid-

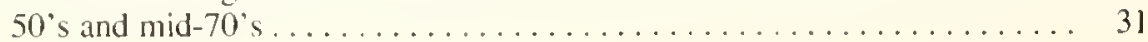


29 Causes of recent wetland losses (mid-1950's to mid-1970's) in the conterminous U.S.; losses to agriculture are highlighted.......... 32

30 Historical losses of wetlands in lowa and California ............. 33

31 Rates of coastal wetland loss in the conterminous U.S. .......... 36

32 Filling of estuarine wetlands for residential housing in Long lsland, New York, and other coastal areas was particularly heavy in the 1950's and 1960's

33 The status of wetland filling and diking in San Francisco Bay prior to the mid-

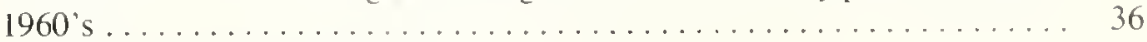

34 Louisiana's coastal marshes are being permanently flooded by Gulf of Mexico

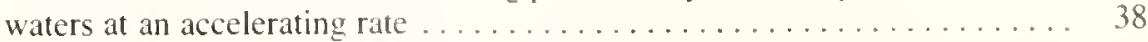

35 Chesapeake Bay and its major tributaries................. 39

36 Chesapeake Bay is one of the more important wintering areas for canvasbacks in North America . . . . . . . . . . . . . . . . . . . . . . . . . . 39

37 Channelization of the Kissimmee River directly destroyed many wetlands and facilitated drainage of more than 100,000 acres of wetlands......... 40

38 Present extent of wetlands in the Florida Everglades; former wetlands are also

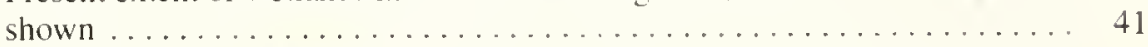

39 Prairie pothole wetlands are the Nation's most valuable waterfowl production

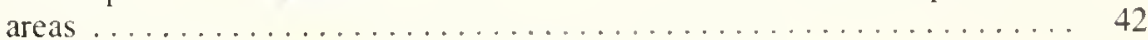

40 Original extent and distribution of Minnesota's wetlands . . . . . . . . . . . 44

41 Present extent and distribution of Minnesota's wetlands ............ 45

42 Prairie pothole wetlands continue to be drained for agriculture . . . . . . . 46

43 Sandhill cranes on a Platte River roost at sunrise. . . . . . . . . . . . . 47

44 Actual and projected losses in bottomland forested wetlands of the Lower

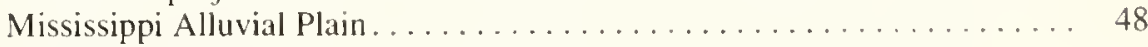

45 Bottomland wetlands are being channelized, clearcut and converted to agricultural uses in many areas of the Southeast . . . . . . . . . . . 49

46 Most of the Nation's pocosin wetlands occur along the coastal plain of North

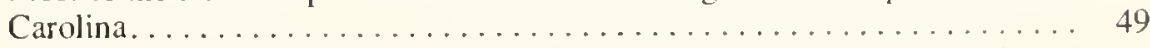

47 Comparison of the extent of natural or only slightly modified pocosins in

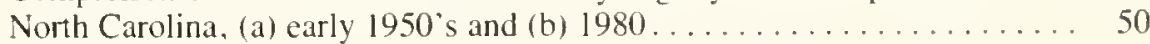

48 Riparian wetlands along rivers and lakes are important to many forms of

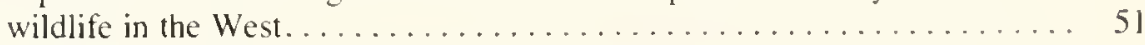

49 Establishing waterfowl production areas is one way that the Service protects

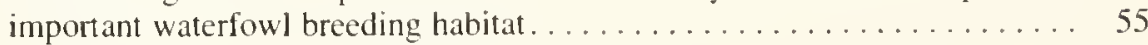

50 Current status of state wetland protection efforts .............. 56 


\section{List of Tables}

No. Page

1 List of major wetland values. ...................... 13

2 Major causes of wetland loss and degradation. ............. 30

3 Examples of wetland losses in various states. . . . . . . . . . . . . 34

4 Examples of recent wetland loss rates. . . . . . . . . . . . . . 35 


\section{Executive Summary}

This report identifies the current status of U.S. wetlands and major areas where wetlands alre in greattent jeopardy from the national standpoint. It also presents existing regional and national information on wetland trends. The report is divided into six chapters: (1) Introduction, (2) What ls a Wetland?, (3) Major Wetland Types of the United States, (4) Why Are Wetlands Important?". (5) Current Status and Trends of U.S. Wetlands, and (6) The Future of America's Wetlands.

Wetlands include the variety of marshes, swamps and bogs that occur throughout the country. They range from red maple swamps and black spruce bogs in the northern states to salt marshes along the coasts to bottomland hardwood forests in the southern states to prairie potholes in the Midwest to playa lakes and riparian wetlands in the western states to the wet tundra of Alaska.

The Fish and Wildlife Service has developed a scientifically sound wetland definition and classification system to inventory the Nation's wetlands. The bulk of America's wetlands fall into two ccological systems: (1) Estuarine System and (2) Palustrine System. The Estuarine System includes salt and brackish tidal marshes, mangrove swamps and intertidal flats, while the Palustrine System encompasses the vast majority of the country's inland marshes, bogs. and swamps.

Wetlands produce many benefits for society besides providing homes for many lish and wildlife species. Some of the more important public values of wetlands include flood control, water quality maintenance, erosion control, timber and other natural products for man's use, and recreation.

Approximately 215 million acres of wetlands existed in the conterminous U.S (i.e. lower 48 states) at the time of the Nation's settlement. In the mid-1970's, only 99 million acres remained, leaving just $46 \%$ of the original wetland acreage. The U.S. wetland resource for the lower 48 states encompassed 93.7 million acres of palustrine wetlands and 5.2 million acres of estuarine wetlands. Wetlands now cover about $5 \%$ of the land surface of the lower 48 states. The total wetland acreage for the lower 48 states amounts to an area roughly the size of California.

Between the mid-1950's and the mid-1970's, about II million acres of wetland were lost, while 2 million acres of new wetland were created. Thus, in that 20 -year interval, a net loss of 9 million acres of wetland occurred. This acreage equates to an area about twice the size of New Jersey.

Annual wetland losses averaged 458,000 acres: 440,000 acres of palustrine losses and 18,000 acres of estuarine wetland losses. This annual loss equals an area about half the size of Rhode Island. Agricultural development was responsible for $87 \%$ of recent national wetland losses. Urban development and other development caused only $8 \%$ and $5 \%$ of the losses, respectively.

The most extensive wetland losses occurred in Louisiana. Mississippi, Arkansas. North Carolina, North Dakota, South Dakota. Nebraska. Florida and Texas. Greatest losses of forested wetlands took place in the lower Mississippi Valley with the conversion of bottomland hardwood forests to larmland. Shrub wetlands were hardest hit in North Carolina where pocosin wetlands are heing converted to cropland or pine plantations or mined for peat. Inland marsh drainage for agriculture was most significant in the Prairie Pothole Region of the Dakotas and Minnesota, Nebraska's Sandhills and Rainwater Basin and Florida's Everglades. Between the mid-1950's and mid-1970's, estuarine wetland losses were heaviest in the Gulf states, i.e., Louisiana. Florida, and Texas. Most ol Louisiana's coastal marsh losses were attributed to submergence by coastal waters. In other areas, urban development was the major direct maninduced cause of coastal wetland loss. Dredge and fill residential development in coastal areas was most significant in Florida, Texas, New Jersey. New York, and California.

The future of the Nation's wetlands depends on the actions of public agencies, private industry, and private groups and individuals. Recent population and agricultural trends point to increased pressure for converting wetlands to other uses, especially cropland. Increased wetland protection elforts by all levels of government and by private parties are needed to halt or slow wetland losses and to enhance the quality of the remaining wetlands. Major protection options are outlined in the report. 

The Fish and Wildlife Service has always recognized the importance of wetlands to waterfowl, other migratory birds and wildlife. Its responsibility for protecting these habitats comes largely lrom international treaties between the United States and other countries concerning migratory birds and from the Fish and Wildlife Coordination Act. Consequently, the Service has been active in protecting these resources through various programs. The National Wildlife Refuge System was established to preserve and enhance migratory bird habitat in strategic locations across the country. More than 12 million ducks breed annually in U.S. wetlands and millions more overwinter here. Waterfowl banded in North Dakota have been recovered in 46 states, 10 Canadian provinces and territories, and 23 other countries.

Since the 1950's, the Service has been particularly concerned about wetland losses and their impact on fish and wildife populations. In 1954, the Service conducted the first nationwide wetlands inventory which focused on wetlands important to waterfowl. This survey was performed to provide information for considering fish and wildlife impacts in land-use decisions. The results of this inventory were published in a well-known Service report entitled "Wetlands of the United States," commonly referred to as Circular 39 (Shaw and Fredine 1956).

Since that survey, wetlands have continued to change due to both natural processes and human activities. The conversion of wetlands for agriculture. residential and industrial developments and other uses has accelerated. During the 1960's, the general public in many states became more aware of wetland values and concerned about wetland losses. They began to realize that wetlands provided significant public benefits besides fish and wildlife habitat, especially flood protection and water quality maintenance. Prior to this time, wetlands were regarded by most people as wastelands, whose best use could only be attained through alteration, e.g. . draining for agriculture, dredging and filling for industrial and housing developments and filling with sanitary landfill. Scientific studies demonstrating wetland values, especially for coastal marshes, were instrumental in increasing public awareness of wetland benefits and stimulating concern for wetland protection. Consequently, several states passed laws to protect coastal wetlands, including Massachusetts (1963), Rhode Island (1965), Connecticut (1969), New Jersey (1970), Maryland (1970), Georgia (1970) and New York (1972). Several of these states subsequently adopted inland wetland protection legislation: Massachusetts, Rhode Island. Connecticut and New York. Most states with coastal wetlands followed the lead of these northeastern states and passed laws to protect these wetlands. During the early 1970's, the Federal government also assumed greater responsibility for wetlands through Section 404 of the Federal Water Pollution Control Act (later amended as the Clean Water Act of 1977). Federal permits are now required for many types of construction in many wetlands, yet most agricultural and silviculturat activities are exempt.

With increased public interest in wetlands and strengthened government regulation, the Service considered how it could contribute to this resource management effort. since it has prime Federal responsibility for protection and management of the Nation's fish and wildlife and their habitat. The Service recognized the need for sound ecological information to make decisions regarding policy, planning, and management of the country's wetland resources. In 1974, the National Wetlands Inventory Project (NWI) was established. The NWI aims to generate scientific information on the characteristies and extent of the Nation's wetlands. The purpose of this information is to foster wise use of U.S. wetlands and to provide data for making quick and accurate resource decisions.

Two very dilferent $k$ inds of information are needed: ( I) detailed maps and (2) status and trends reports. First. detailed wetland maps for geographic areas of critical concern are needed for impact assessment of site-specific projects. These maps serve a purpose similar to the Soil Conservation Service's soil survey maps, the National Oceanic and Atmospheric Administration's coastal geodetic survey maps, and the Geological Survey's topographic maps. Detailed wetland maps are used by local. state and Federal agencies as well as by private industry and organizations for many purposes, including comprehensive resource management plans, environmental inpact assessments, permit reviews, lacility and corridor siting, oil spill contingency plans, natural resource inventories, wildlife surveys and other uses. Wetland maps have been produced for Hawaii, $30 \%$ of the lower 48 states and $6 \%$ of Alaska. Present plans are to complete wetland mapping for at least $55 \%$ of the conterminous U.S. and $16 \%$ of Alaska by 1988. Secondly, national estimates of the current status and trends (i.e.. losses and gains) of wetlands are needed in order to provide improved information for reviewing the effectiveness of existing Federal programs and policies, for identifying national or regional problems and for general public awareness. A technical report of these trends has been recently published (Frayer, et al. 1983).

The purpose of this report is to inform government agencies, private industry and organizations, the scientific community, and the general public about the current status and historical trends of U.S. wetlands. It also identifies key regions where wetlands remain in greatest jeopardy and presents management recommendations for improving wetland protection. The Service's study of recent wetland gains and losses provides the national perspective for this report and targets current problem areas. Other studies address regional and historical wetland changes. These sources provide the necessary documentation for presenting a complete picture of trends in America's wetlands and the basis for identifying future problems. While focusing on wetland trends, the report begins with discussions of the concept of wetland, major types of U. S. wetlands and wetland values. This background is essential for understanding the significance of what is happening to the Nation's wetlands. Appendix A provides a glossary of common and scientific names of plants refersed to in this report. 


\section{WHAT IS A WETLAND?}

All of us are familiar with marshes and swamps esther through our own observations or readings. The term "wetland," however, may be relatively new to many people. Essentially, wetlands include the wide variety of marshes. swamps and bogs that occur throughout the country. They range from red maple swamps and black spruce bogs in the northern states to salt marshes along the coasts to bottomland hardwood forests in the southern states to prairie potholes in the Midwest to playa lakes and cottonwood-willow riparian wetlands in the western states to the wet tundra of Alaska.

Wetlands usually lie in depressions or along rivers, lakes, and coastal waters where they are subject to periodic flooding. Some, however, occur on slopes where they are associated with groundwater seeps. Conceptually, wetlands lie between well-drained upland and permanently flooded deep waters of lakes, rivers and coastal embayments (Figure 1). Recognizing this, one must determine where along this natural wetness continuum wetland ends and upland begins. Many wetlands form in distinct depressions or basins that can be readily observed. However, the wetland-upland boundary is not al watys that easy to identify. Wetlands may occur in almost imperceptibly shallow depressions and cover vast acreages. In the Prairie Pothole Region, wetland boundaries change over time due to varying rainfall pattems. In these situations, only a skilled wetland ecologist or other specialist can identify the wetland boundary with precision.

Wetlands were historically defined by scientists working in specialized fields. such as botany or hydrology. A botanical definition would focus on the plants adapted to flooding and/or saturated soil conditions, while a hydrologist's definition would emphasize the position of the water table relative to the ground surface over time. A more complete definition of wetland involves a multidisciplinary approach. The Service has taken this approach in developing its wetland definition and classification system.

\section{The Fish and Wildlife Service's Definition of Wetlands}

Prior to conducting an inventory of the Nation"s wetlands, the Service had to first define what a wetland is and where along the soil moisture gradient to draw the line between wetland and upland. To do this, the Service enlisted the help of the Nation's leading wetland scientists and selected four of them to develop a new wetlands classification system (Figure 2). The authors represented several disciplines including waterfowl biology, hydrology, wetland ecology and marine biology.

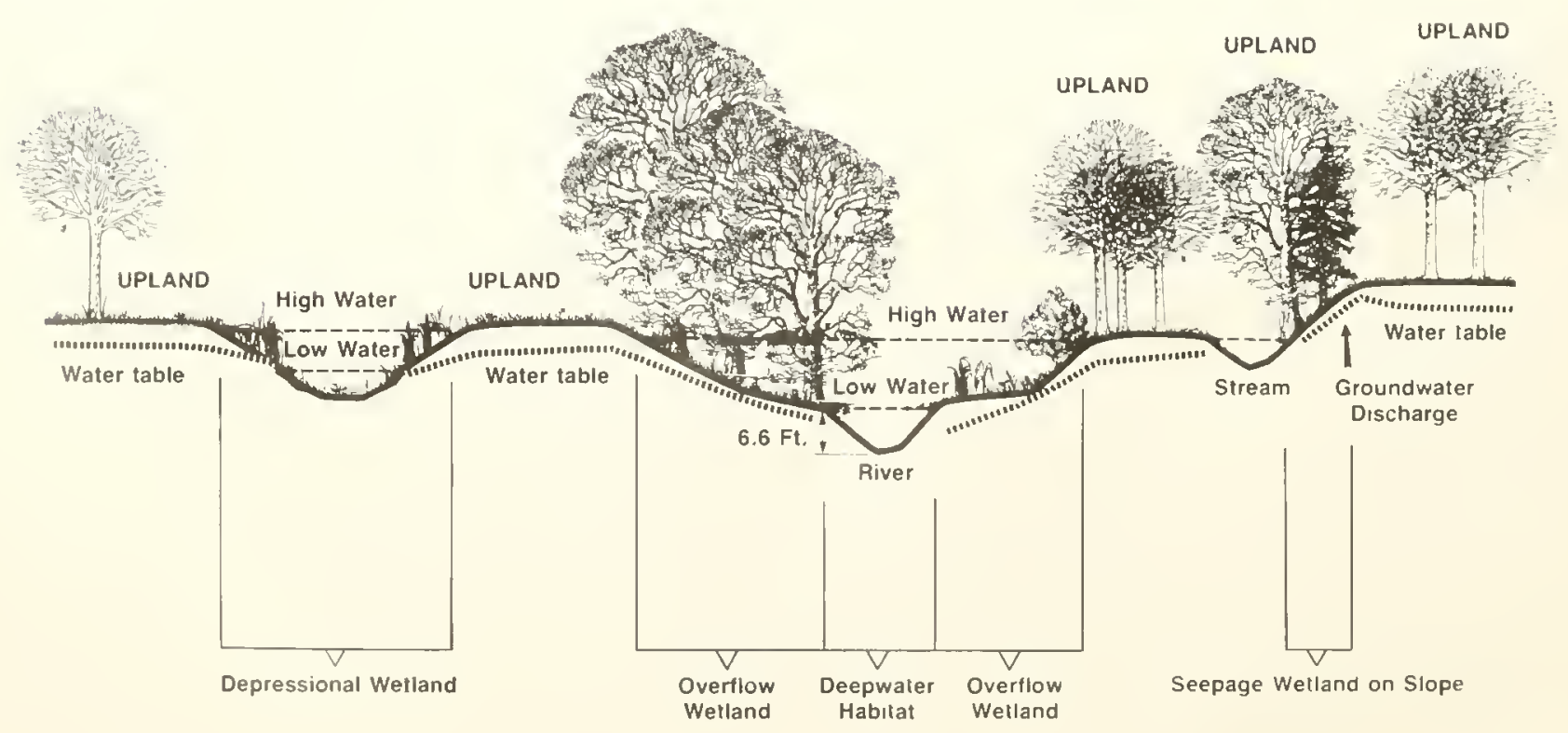

Fig. 1. Schematic diagram showing wetlands, deepwaler habitats, and uplands on landscape. Note differences in wetlands due to hydrology and lopographic location. 
Bıological Services Pronram

\section{Classification of Wetlands and Deepwater Habitats of the United States}

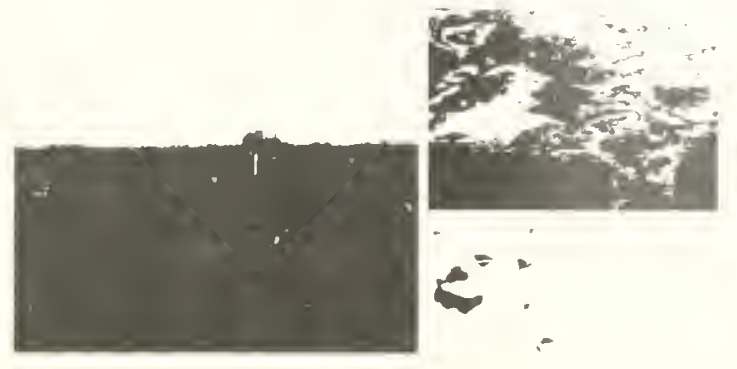

Fish and Wildife Service

U.S. Department of the Interior

Fig. 2. The Fish and Wildlife Service's official wetland classification report.

In developing an ecologically sound definition of wetland, it was aeknowledged that "there is no single, correet, indisputable, ecologically sound definition for wetlands, primarily beeause of the diversity of wetlands and because the demarcation between dry and wet environments lies along a continuum" (Cowardin, et al. 1979). Previous wetland definitions grew out of different needs for defining wetlands among various disciplines, e.g., wetland regulators, waterfowl managers. hydrologists, flood control engineers and water quality experts. The Service needed a definition that would allow accurate identification and delineation of the Nation's wetlands for resource management purposes.

The Service specifically defines wetlands as follow's:

"Wetlands are lands transitional between terrestrial and aquatie systems where the water table is usually at or near the surface or the land is covered by shallow water. For purposes of this classification wetlands must have one or more of the following three attributes: 1) at least periodically, the land supports predominantly hydrophytes: 2) the substrate is predominantly undrained hydric soil; and 3 ) the substrate is nonsoil and is saturated with water or covered by shallow water at some time during the growing season of each year."

(Cowardin, et al. 1979).

In defining wetland from an ecological standpoint, the Service emphasizes three key attributes of wetland: I) hydrology - the degree of flooding or soll saturation, 2) wetland vegetation (hydrophytes), and 3) hydric soils. All areas considered wetland must have enough water at some time during the growing season to stress plants and animals not adapted for life in water or saturated soils Most wetlands also have hydrophytes and hydric soil present. The Service is preparing a list of hydrophyte and the Soil Conservation Service is developing a list (1) hydrie soils to help lurther define wetland

It is interesting to note that a similar approach to wetland definition was recently used in a Federal court cise in Louisiana to make a legal wetland determination (Scott 1979). In his ruling. the juilge decided that the area in dispute constituted wetland according to Section 404 of the Clean Water Act because: I) records showed that virtually all of the tract was flooded every other year (hydrology criterion), 2) the soil types were classified as wetland soils, with two exceptions where information was inadequate (hydric soil eriterion), and 3) vegetation capable of surviving and reproducing in wetlands predominated the site (hydrophyte criterion). Thus, the rationale for using these three key attributes now has legal precedent.

Particular attention should be paid to the reference to flooding or soil saturation during the growing season in the Service"s definition. When soils are covered by water or saturated to the surface, free oxygen is usually not available to plant roots. Most plant roots must have aecess to free oxygen for respiration and growth; flooding during the growing season presents problems for the growth and survival of most plants. In a wetland situation, plants must be adapted to cope with these stressful conditions. If flooding occurs only in winter when the plants are dormant, there is little or no effect on them.

It is important to note that the Service does not include permanently flooded deepwater areas as wetland. Instead, these waterbodies (generally deeper than six feet) are defined as deepwater habitats, sinee water and not air is the principal medium in which dominant organisms must live

In summary, the Service has developed a scientifieally sound definition of wetland based on the degree of flood ing or soil saturation and the presence of wetland plants and/or hydrie soils. It is the product of four years of field testing and review by the scientific community. Consequently, the Service's concept of wetland is being widely accepted as the national and international standard for identifying wetland.

\section{References}

Cowardin, L.M., V. Carter, F.C. Gotet, and E.T. LaRoe. 1979. Classfication of Wetlands and Deepwater Habitats of the United State, U.S. Fish and Wildlife Service. FWS/OBS-79:31. 103 pp.

Scott, N.S. 1979. Opinion. Civil Action No. 78-1428. The Avoyclles Sportsmen's League, Inc, et. al. v. Clifford L. Alexander, et. al. U.S. District Court, Western District of Louisiana, Alexandria Division. $20 \mathrm{pp}$ 


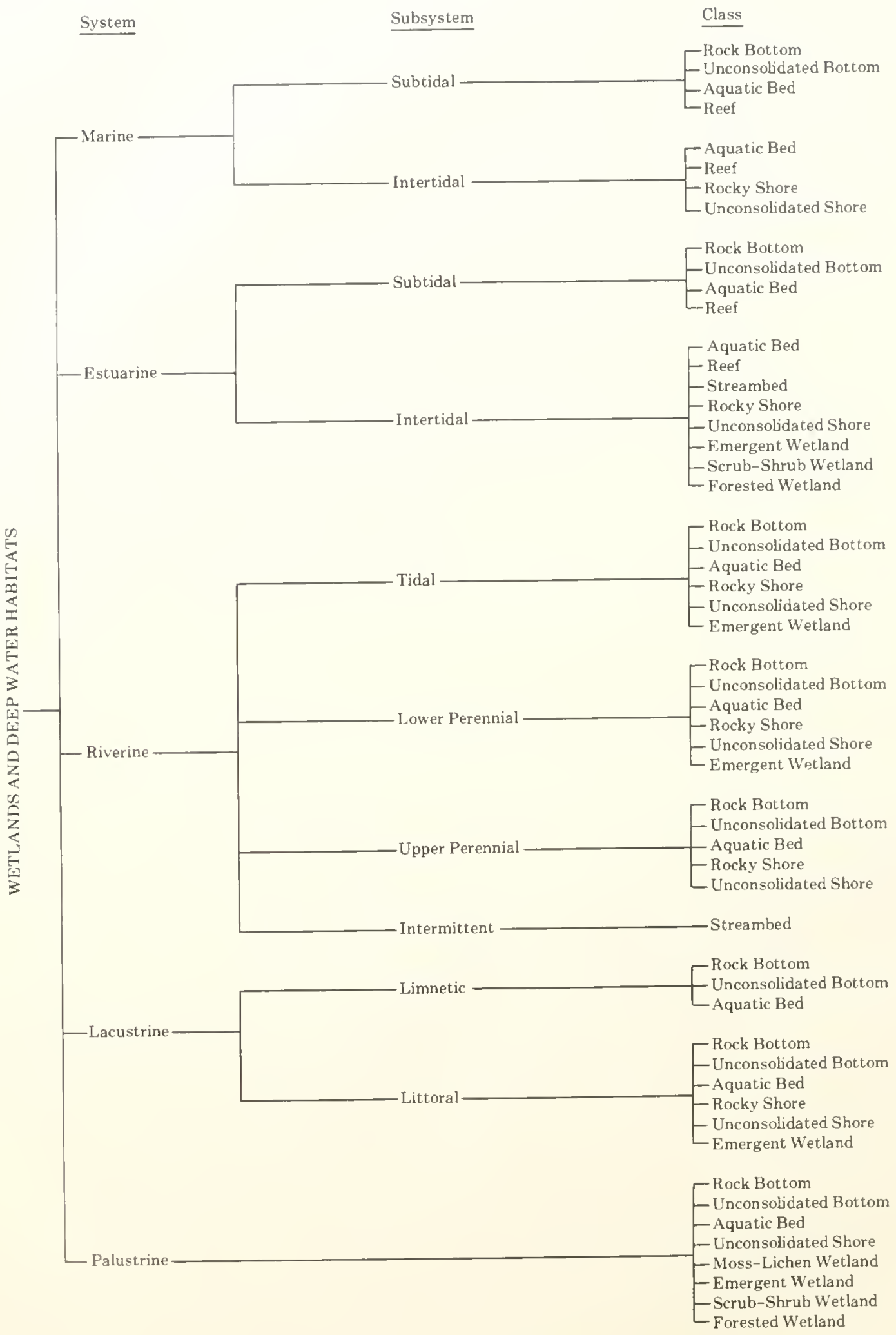

Fig. 3. Classification hierarchy of wetlands and deepwater habitats, showing systems, subsystems, and classes. The Palustrine System does not include deepwater habitats (Cowardin, et al. 1979). 


\section{MAJOR WETLAND TYPES OF THE UNITED STATES}

Wetlands occur in every state of the country and due to regional differences in climate, vegetation, soil and hydrologic conditions. they exist in a variety of sizes. shapes and types. Although more abundant in other areas. wetlands even exist in deserts.

The Service's classification system (Cowardin. et al. 1979) groups wetlands according to ecologically similar characteristics. It first divides wetlands and deepwater habitats into five ecological systems: (1) Marine, (2) Estuarine, (3) Riverine. (4) Lacustrine, and (5) Palustrine (Figure 3). The Marine System generally consists of the open ocean and its associated coastline (Figure 4 ). It is mostly a deepwater habitat system, with mame wetlands limited to intertidal areas like beaches, rocky shores and some coral reefs. The Estuarine System includes coastal wetlands like salt and brackish tidal marshes, mangrove swamps, and intertidal liats, as well as deepwater bays. sounds and coastal rivers. The Riverine System is limited to freshwater river and stream channels and is mainly a deepwater habitat system. The Lacustrine System is also a deepwater dominated system. but includes standing walterbodies like lakes, reservoirs and deep ponds. The Palustrine System encompasses the vast majority of the country's inland marshes, bogs and swamps and does not include any deepwater habitat. Characteristics of the major wetland types in the U.S. are described in the following sections. The discussion focuses on estuarine and palustrine wetlands because they are the most abundant types.

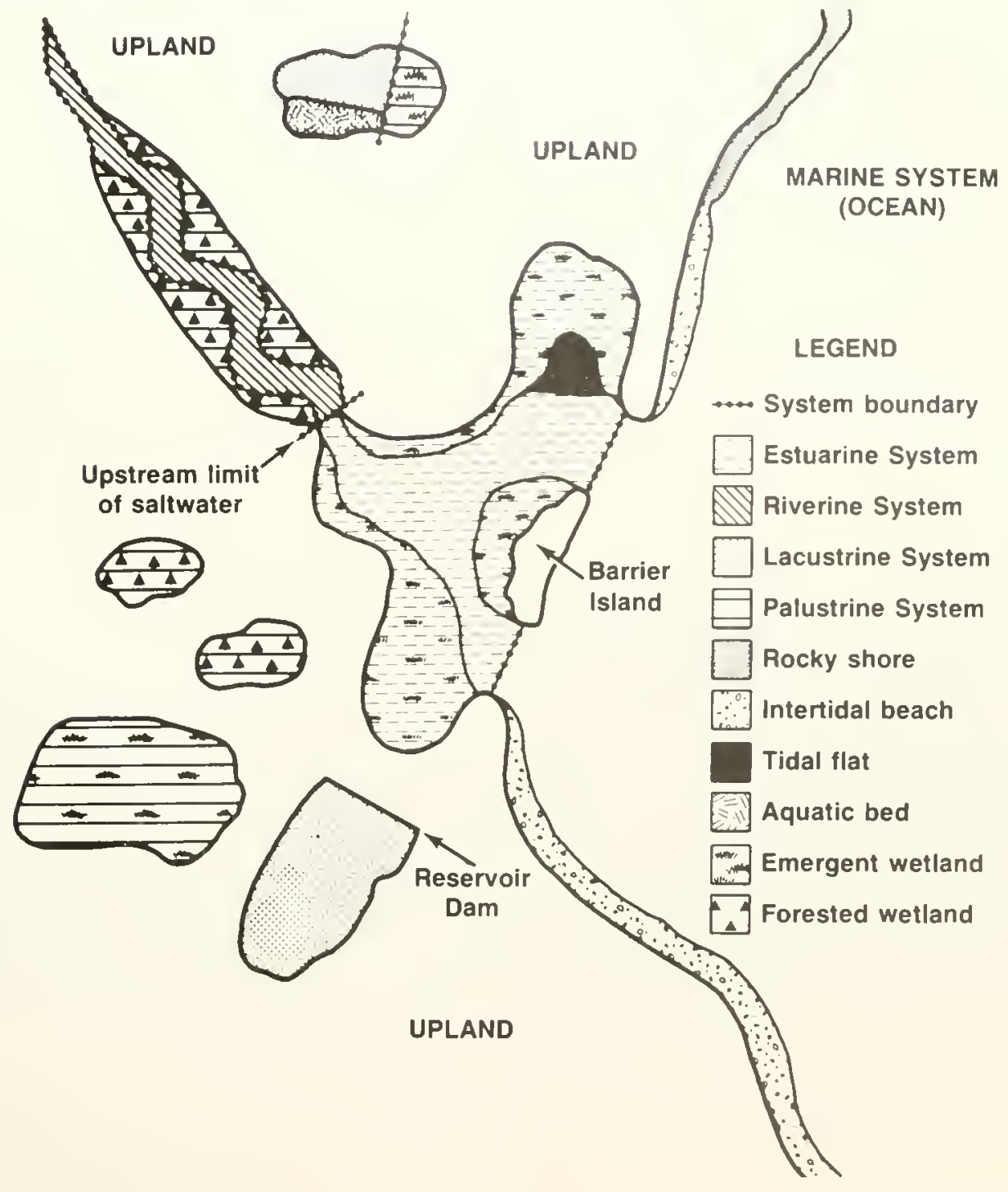

Fig. 4. Diagram showing major wetland and deepwaler habitat systems. 


\section{Estuarine Wetlands}

Estuarine wetlands are found along the U.S. coastline and are associated with estuaries or hrackish tidal waters. They are represented by three major types: (1) emergent wetland, (2) intertidal flat, and (3) scrub-shrub wetland. Other coastal wetiands include intertidal coral and mollusk reefs, rocky shores, and beaches.

\section{Estuarine Emergent Wetlands}

Estuarine emergent wetlands are dominated by grass or grass-like plants (Figure 5). They are commonly called "salt marshes" and "brackish tidal marshes".

Salt marshes characteristically lie behind barrier islands and beaches along all coasts in relatively high salinity waters. They are best represented along the Alaskan, Atlantic and Gulf coasts. Salt marshes are flooded by tides for varying periods depending on elevation and tidal amplitude. Two distinct zones can be observed hased on differences in lrequency and duration of flooding and associated vegetation: (1) regularly flooded marsh and (2) irregularly flooded marsh (Figure 6). The regularly flooded marsh is flooded and exposed at least once daily by the tides. In New England, this marsh is generally limited to tidal creek banks. while in the Southeast, it is the dominant coastal wetland type covering vast acreages. Along the Atlantic and Gulf coasts, smooth cordgrass dominates the regularly flooded marsh, while on the West coast, California cordgrass prevails. These grasses are among the most productive marsh plants. Lying above the regularly flooded zone, the irregularly flooded marsh is exposed to air for long periods and flooded only at irregular intervals, usually monthly during spring and storm tides. Vegetation in this zone is more varied, including salt hay cordgrass, spikegrass, black grass, alkaligrass, Baltic rush, black needlerush, glassworts, saltworts, sea ox-eye, high-tide bush, reed, bulrushes, asters and switchgrass. On the West coast, Lyngbye's sedge, hairgrass and jaumea are other important species. Salt marshes along the Beaufort Sea in Alaska are dominated by alkaligrass and sedges.

Moving upstream in coastal rivers where seawater is diluted by freshwater, the brackish tidal marshes can bz found. Salinity here fluctuates greatly with the tides, river flow and the seasons. Nearest the salt marshes, black needlerush dominates brackish marshes along the South Atlantic and Gulf coasts, while big cordgrass, narrowleaved cattail and bulrushes are important in more northern areas. As the upstream limit of salt water influence is approached, a highly diverse assemblage of emergent plants characterizes these marshes, including big cordgrass, narrow-leaved cattail, pickerelweed, wild rice, giant cutgrass, marsh mallow, arrowheads, smartweeds, sedges, bulrushes, beggar's-ticks and reed. Most of these plants, however, reach their maxinum abundance in the Nation's inland wetlands.

\section{Estuarine Intertidal Flats}

Intertidal flats often lie seaward of tidal marshes and mangroves, at river mouths or along rocky coasts. They also occur as barren areas within the high marsh in high 

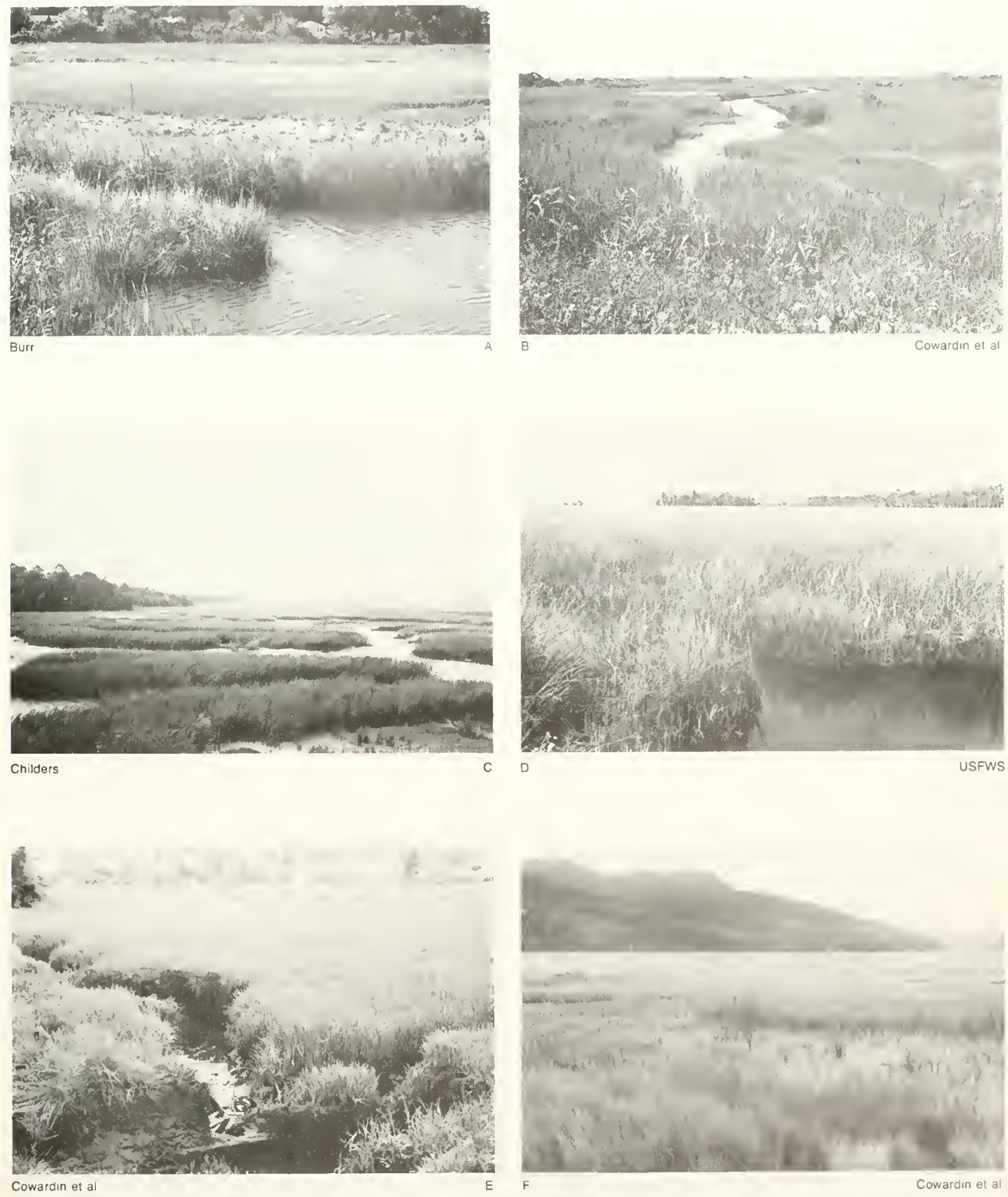

Fig. 5. Examples of estuarine emergent wetlands, (a) mixed plant community of irregularly flooded marsh, (b) reed-salt hay cordgrass marsh, (c) regularly flooded cordgrass marsh. (d) black needlerush marsh. (e) Lyngbye's sedge marsh and (f) Alaskan irregularly flooded marsh. 


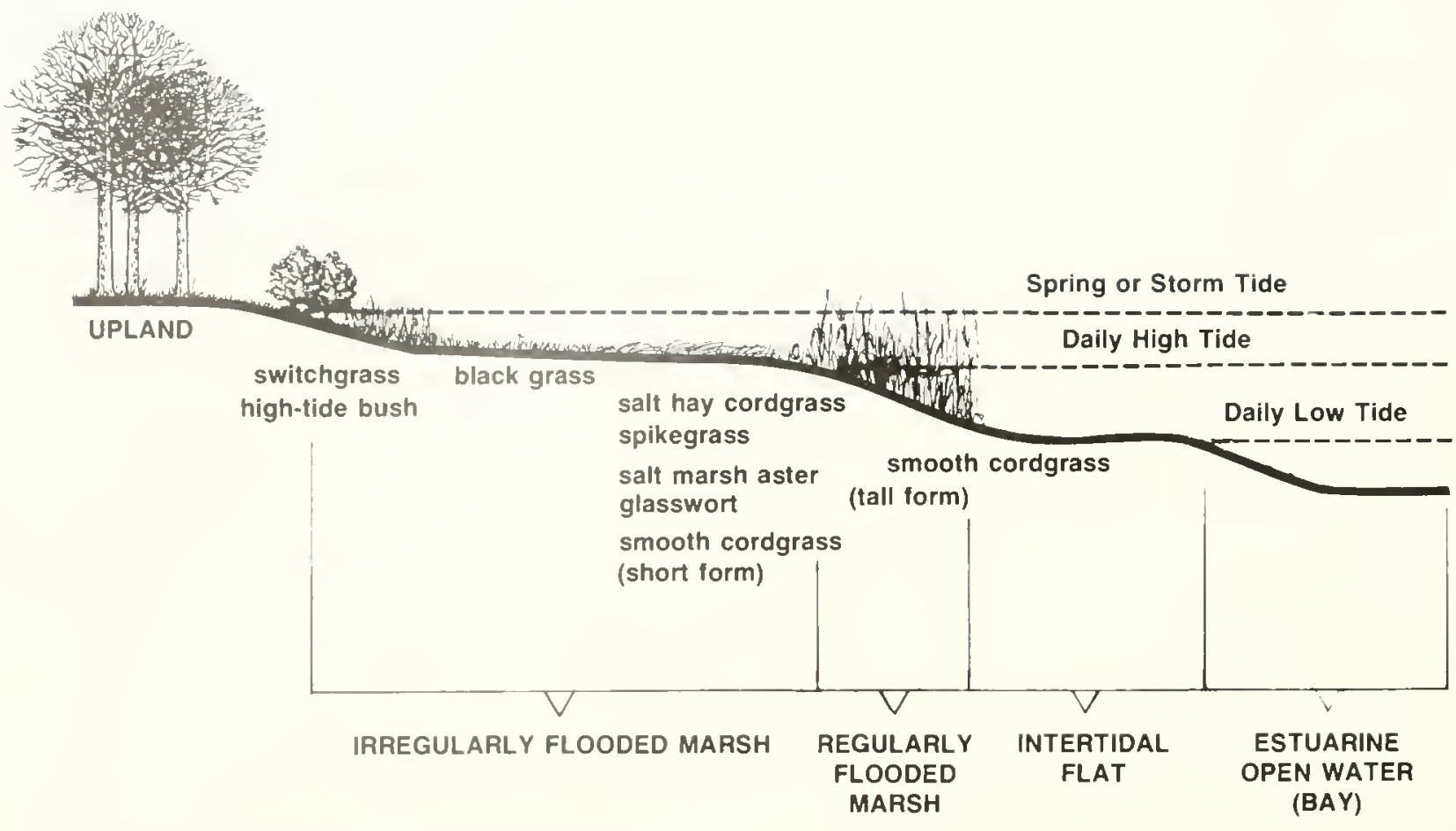

Fig. 6. Cross-sectional diagram of a Northeastern salt marsh.

salinity areas. Tidal flats appear at low tide largely as unvegetated expanses of mud or sand, although microscopic plants like diatoms, bluegreen algae and dinoflagellates may be extremely abundant (Figure 7). On oceasion, macroscopic algae like sea lettuce may locally dominate these flats. These wetlands are particularly extensive in areas with high tidal ranges such as Alaska and Maine.

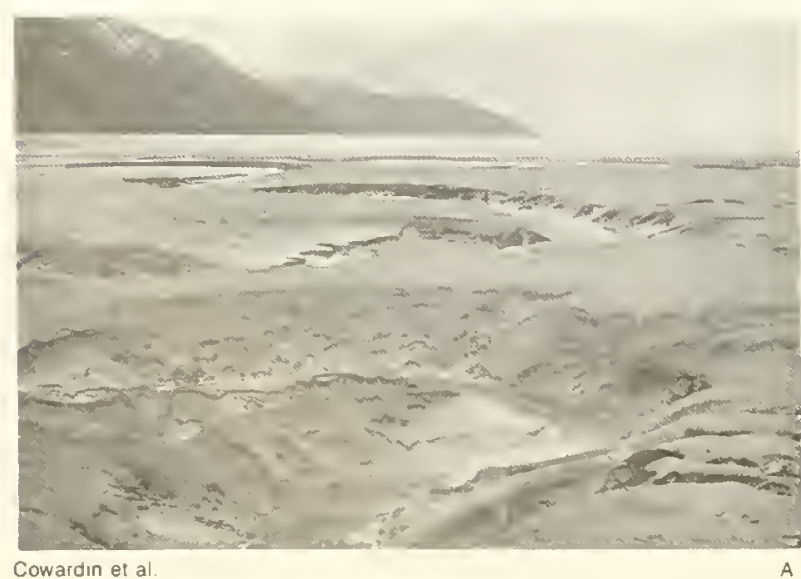

\section{Estuarine Scrub-Shrub Wetlands}

Estuarine scrub-shrub wetlands are characterized by salt-tolerant woody vegetation less than 20 feet in height. Common estuarine shrubs along the Atlantic and Gulf coasts are high-tide bush and sea myrtle. Estuarine shrub wetlands are perhaps best represented by mangrove swamps. which have a limited distribution in the U.S.

Fig. 7. Examples of estuarine intertida! flats, (a) Alaska and (b) Virginia. 

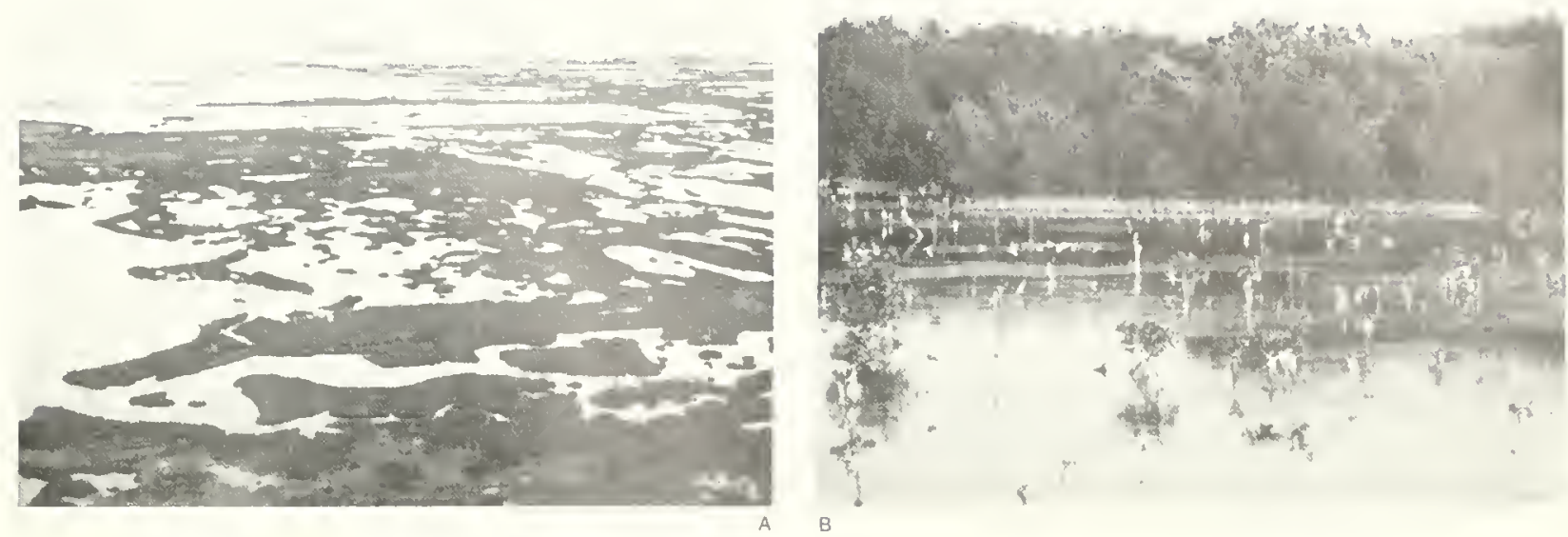

Fig. 8. Mangrove-dominated estuarine scrub-shrub wellands of Florida, (a) aerial view and (b) close-up of red mangroves

(Figure 8). Mangroves are generally found south of the $30^{\circ} \mathrm{N}$ Latitude and reach their maximum abundance in Florida, Puerto Rico, and the Virgin Islands. These wetlands are dominated by tall shrub forms of two mangroves: (1) red mangrove and (2) black mangrove. Red mangroves dominate the regularly flooded zone, while black mangroves characterize higher irregularly flooded areas. Salt marshes of smooth cordgrass, black needlerush, spikegrass, and saltwort may be closely associated with Florida’s mangrove swamps.

\section{Palustrine Wetlands}

Palustrine wetlands occur in the interior of the country and largely consist of freshwater wetlands, although inland salt and brackish marshes exist in arid and semiarid areas. Palustrine wetlands are represented by three major types: (1) emergent wetland, (2) scrub-shrub wetland and (3) forested wetland. Shallow open waterbodies such as ponds and playa lakes (less than 6.6 feet deep) are also considered wetland by the Service.

\section{Palustrine Emergent Wetlands}

Palustrine emergent wetlands are dominated by herbaceous vegetation including certain grasses, cattails, rushes and sedges (Figure 9). These wetlands are commonly referred to by a variety of terms, including "marsh", "wet meadow", "fen", and "inland salt marsh", depending on the region of the country and individual characteristics. Emergent wetlands may be flooded for variable periods from as little as a couple of weeks early in the growing season to permanently flooded throughout the year. Some palustrine marshes are flooded by fresh tidal waters, mainly along the Atlantic, Gulf, and Alaskan coasts. Differences in local hydrology affect the wetness of a given marsh and the corresponding vegetative community. This is particularly evident in the Prairie Pothole Region. Here wetland vegetation growing in glacial depressions often creates a distinct zonal pattern related to differences in water regime (Figure 10 ). Emergent wetlands occur in a variety of situations, including along the margins of rivers and lakes, in upland depressions. in seepage areas on gentle slopes and in saturated permafrost areas of Alaska. Common marsh plants include cattails, wild rice, sedges, rushes, bulrushes, spikerushes, rice cutgrass. maidencane, reed. arrowheads, pickerelweed, smartweeds, and burreeds. 

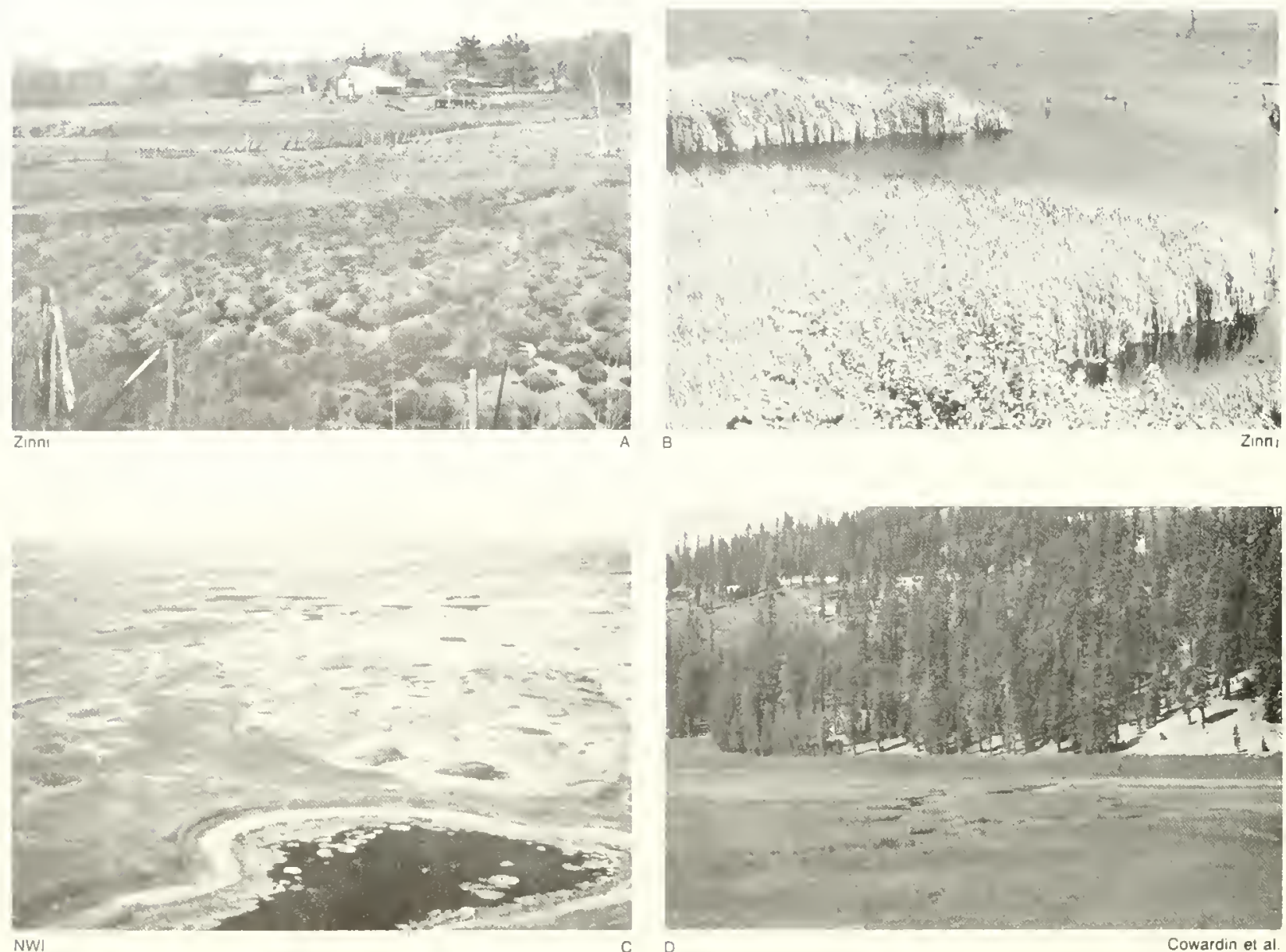

Fig. 9. Examples of palustrine emergent wetlands, (a) Northeastern sedge meadow, (b) cattail marsh, (c) prairie pothole wetland, and (d) Western sedge meadow.

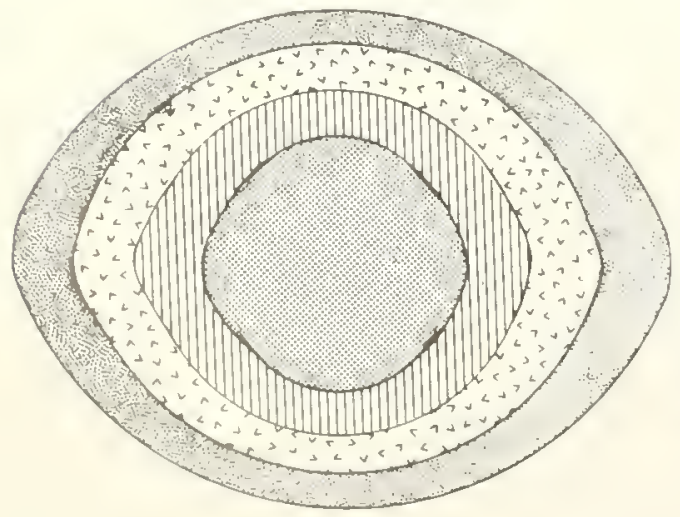

LEGEND

Water Regime

Dermanently Flooded

III Semipermanently Flooded

[S Seasonally Flooded

Temporarily Flooded

\section{Examples of Common Plants}

western widgeongrass, pondweed, muskgrass

slender bulrush, cattail, hardstem bulrush

burreed, smartweed, whitetop, spikerush

false aster, bluegrass, prairie cordgrass. saltgrass

Fig. 10. Generalized vegetation zones of a pothole wetland in relationship to water regime (from Stewart and Kantrud 1972). 

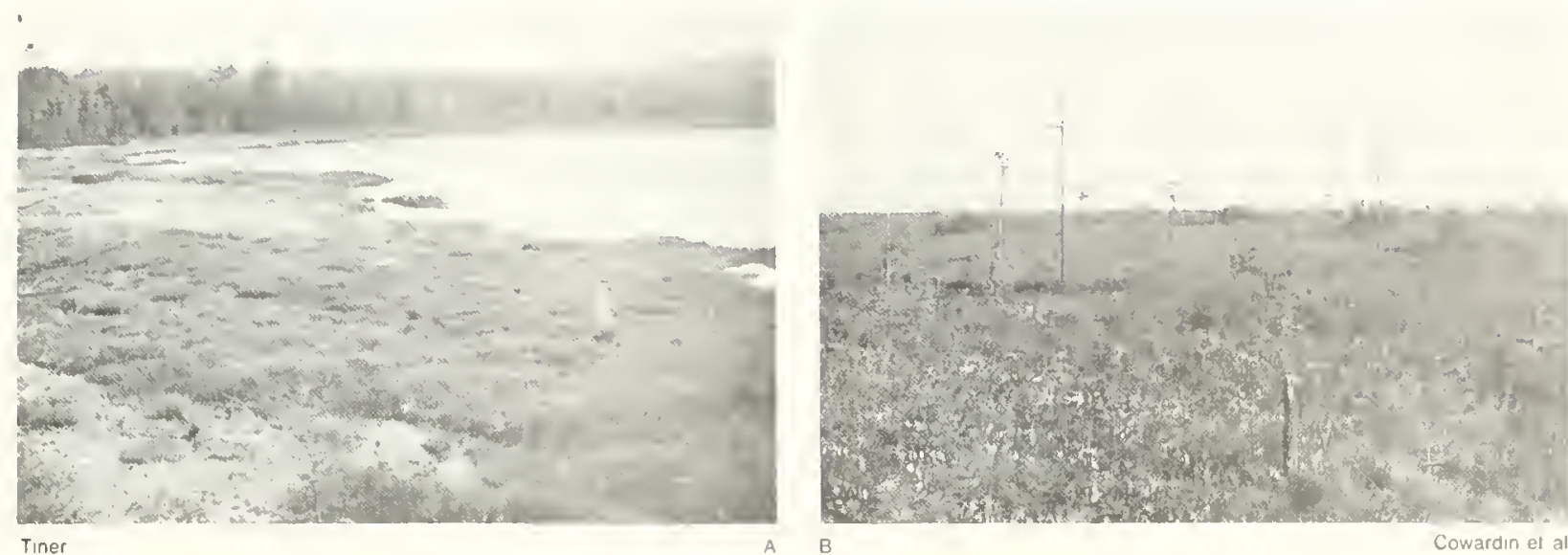

Fig. 11. Examples of palustrine scrub-shrub wetlands, (a) Northern leatherleaf bog and (b) pocosin.

\section{Palustrine Scruh-Shrub Wetlands}

Freshwater wetlands dominated by woody vegetation less than 20 feet tall represent palustrine scrub-shrub wetlands (Figure 11). Although not as abundant as palustrine emergent and forested wetlands, they occur widely throughout the Nation. These shrub-dominated wetlands are commonly called "bog", "pocosin", "shrub-carr", or "shrub swamp" in different parts of the country.

Northern and southern peat bogs are particularly interesting types of scrub-shrub wetlands. Both types are rarely flooded and are generally characterized by a saturated organic soil with the water table at or near the surface for most of the year. Northern bogs are prevalent in isolated depressions, along river courses and along the margins of lakes in states like Alaska, Maine, Michigan, Minnesota, New York and Wisconsin. Typical northern bog plants include leatherleaf, sweet gale, cotton grass, peat moss, bog rosemary, Labrador tea, cranberry, bog laurel, and sedges as well as stunted trees of black spruce, larch. lodgepole pine, and balsam fir. Southern bogs occur along the southeastern Coastal Plain and are locally called "pocosins." They are found on broad flat plateaus usually apart from large streams. Pocosins are dominated by evergreen shrubs of pond pine, sweet bay, inkberry, fetterbush and titi. Other important scrub-shrub wetlands in the U.S. are characterized by buttonbush, alders, willows, dogwoods and saplings of tree species like red maple and cottonwood.

\section{Palustrine Forested Wetlands}

Forested wetlands dominated by trees taller than 20 feet occur mostly in the eastern half of the United States and Alaska (Figure 12). In the East, they are the most abundant wetland type. They include such diverse types as black spruce bogs, cedar swamps, red maple swamps, and bottomland hardwood forests. In the Prairie Pothole
Region of the Dakotas, forested wetlands are relatively uncommon. As in other inland wetlands. flooding is extremely variable depending on regional climate, topographic position and local hydrology. In the North. important trees of the wetter swamps are red maple, ashes, northern white cedar, black spruce and larch. Bald cypress, water tupelo, red maple, black gum. Atlantic white cedar, overcup oak, and black willow are common in southern wet swamps. In the Northwest, western hemlock, red alder and willows are important species. Drier swamps, those flooded only briefly during the growing season. are characterized by silver maple, pin oak, sycamore and beech in the North and by sweet gum, loblolly pine, slash pine, tulip poplar, beech, black walnut, sycamore, water hickory, pignut hickory and various oaks (e.g., water, laurel, and willow) in the South. Cottonwood, box elder, willows, green ash and elms dominate riparian wetlands along western streams. Black spruce. larch. lodgepole pine and balsam poplar are the major forested wetland species in Alaska.

\section{References}

Cowardin, L.M. . V. Carter. F.C. Golet, and E. T. LaRoe. 1979. Classification of Wetlands and Deepwater Habilats of the United Stales U.S. Fish and Wildlife Service. FWS OBS-79/31. 103 pp.

Hofstetter, R.H. 1983. Wetlands in the United States. In: A J.P. Gore (editor). Mires: Swamp, Bog, Fen and Moor. Elsevier Scientific Publishing Co., Amsterdam. pp. 201-244

MacDonald, K. B. 1977. Plant and animal communities of Pacific North American salt marshes. tn: V.J. Chapman (editor). Wet Coastal Ecosystens. Elsevier Scientific Publishing Co., Amsterdam. pp. 167-191.

Reimold, R.J 1977. Mangals and salt marshes of eastern United States. tn: V.J. Chapman (editor). Wet Coastal Ecosystems. Elsevier Scien tific Publishing Co. Amsterdam. pp. 157-166.

Shaw, S.P. and C.G Fredine. 1956. Wetlands of the United States Their Extent and Their Value to Waterfowl and Other Wildlife. U.S Fish and Wildlife Service. Circular 3967 pp.

Stewar, R.E. and H. A. Kantrud. 1972. Vegetation of Pranrie Potholes, North Dakola. in Relation to Quality of Water and Other Environmental Factors. U.S. Geol. Survey. Prof. Paper 585-D. $36 \mathrm{Pp}$ 

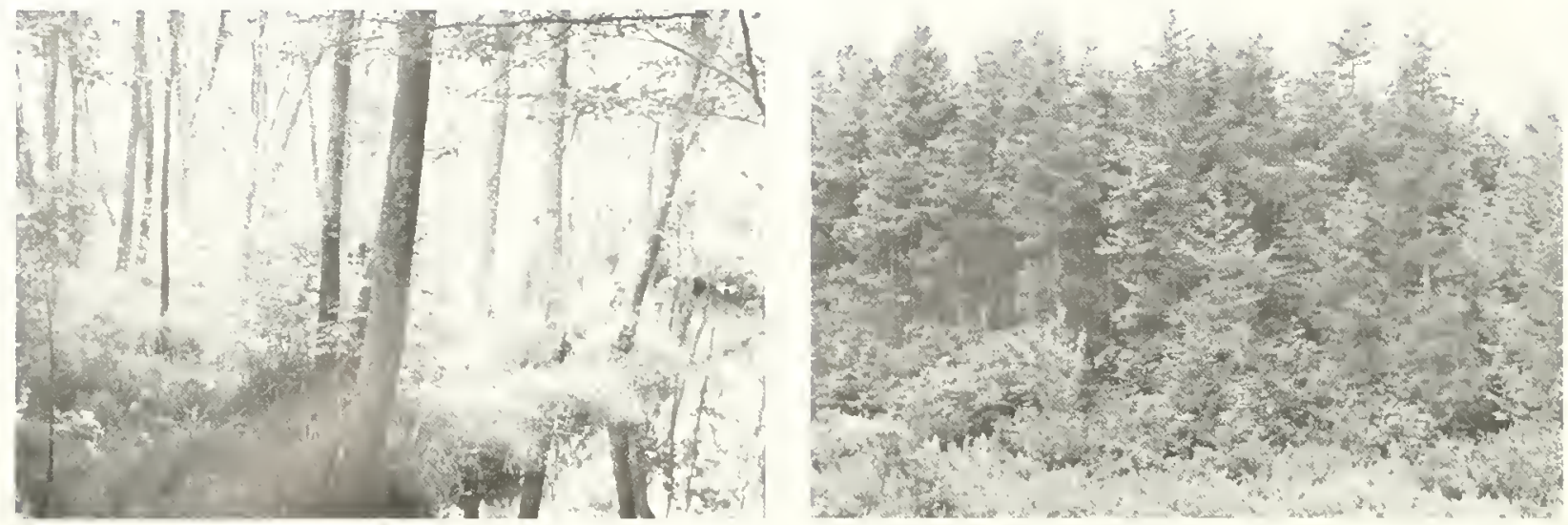

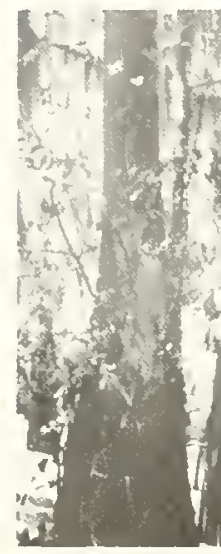

USFWS

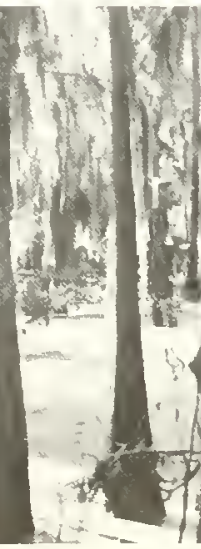
11

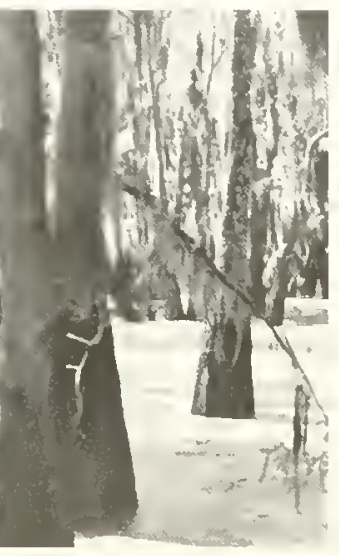

c

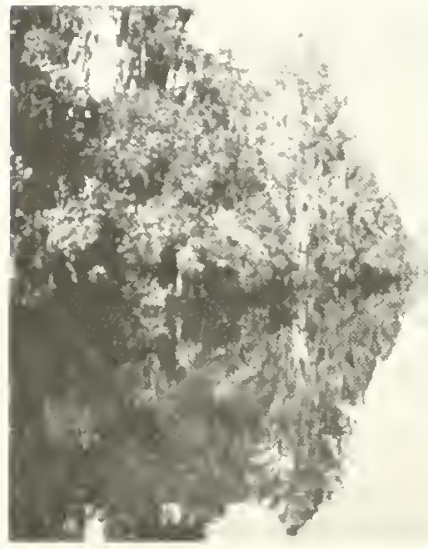

D

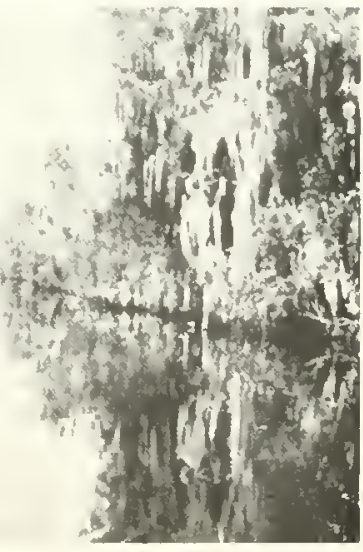

USFWS

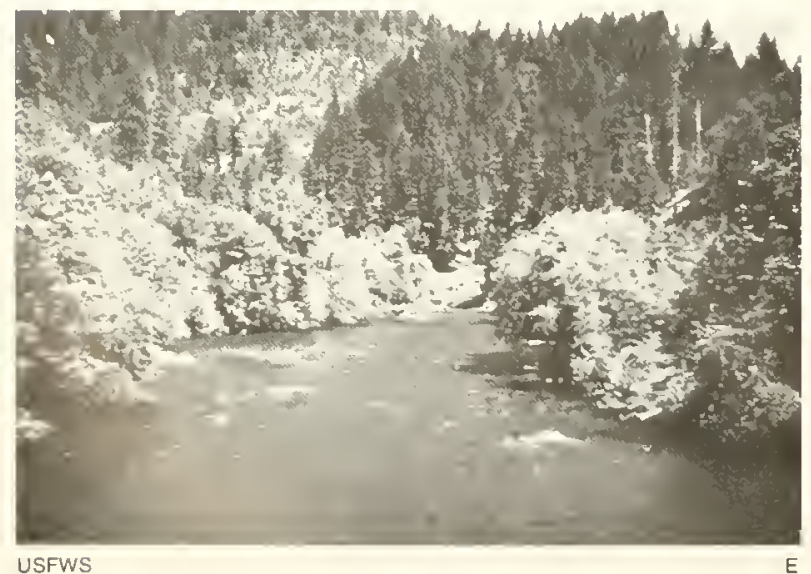

USFWS

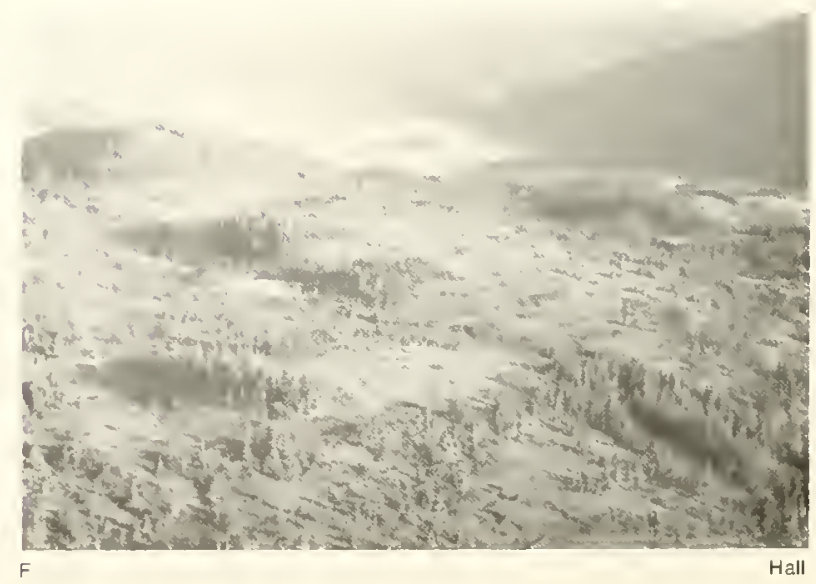

Fig. 12. Examples of palustrine forested wetlands, (a) red maple swamp. (b) Atlantic white cedar swamp, (c) bald cypress swamp. (d) bottomland hardwood swamp, (e) riparian forested wetland, and (f) Alaskan forested wetland mixed with scrub-shrub wetland. 


\section{WHY ARE WETLANDS IMPORTANT?}

Although olten used by many people for hunting, trapping and fishing. wetlands were largely considered wastelands whose best use could only be attained through "reclamation projects." such as drainage for agriculture and filling for industrial or residential development. Much to the contrary, wetlands in their natural state provide a wealth of values to society (Table 1). Wetland benefits can be divided into three basic categories: (1) fish and wildlife values, (2) environmental quality values and (3) socio-economic values. The following discussion emphasizes the more important values. For an indepth examination of wetland value, the reader is referred to "Wetland Functions and Values: The State of Our Understanding" (Greeson, et al. 1979). In addition, the Service has created a wetland values database which records abstracts of over 2000 articles (Stuber 1983).

Table 1. List of major wetland values.

\section{FISH AND WILDLIFE VALUES}

- Fish and Shellfish Habitat

- Waterfowl and Other Bird Hahitat

- Furbearer and Other Wildlife Habitat

ENVIRONMENTAL QUALITY VALUES

- Water Quality Maintenance

- Pollution Filter

- Sediment Removal

- Oxygen Production

- Nutrient Recycling

- Chemical and Nutrient Absorption

- Aquatic Productivity

- Microclimate Regulator

- World Climate (Ozone layer)

SOCIO-ECONOMIC VALUES

- Flood Control

- Wave Damage Protection

- Erosion Control

- Groundwater Recharge and Water Supply

- Timber and Other Natural Products

- Energy Source (Peat)

- Livestock Grazing

- Fishing and Shellfishing

- Hunting and Trapping

- Recreation

- Aesthetics

- Education and Scientific Research

\section{Fish and Wildlife Values}

The variety of wellands across the country create halytats for many forms of fish and wildife. Some aninals spend their entire lives in wetlands, while others use wetlands primarily for reproduction and nursery grounds. Numerous fish and wildife frequent marshes and swamps for feeding or feed on organisms produced in wetlands. whereas many animals visit wetlands for drinking water Wetlands are also crucial for survival of numerous endangered animals.

\section{Fish and Shellfish Habinat}

Both inland and coastal wetlands are essential to maintaining important fish populations. Estuarine wetlands are also important producers of shrimp, crabs, oysters and clams for man's consumption.

Approximately two-thirds of the major U.S. commercial fishes depend on estuaries and salt marshes for nursery or spawning grounds (McHugh 1966). Among the more familiar wetland-dependent fishes are menhaden, bluefish, fluke, sea trout, spot, mullet, croaker, striped bass, and drum. Coastal marshes along the Atlantic and Gulf coasts are most important in this regard. In the Pacific Northwest, coastal wetlands along spawning streams are vital to many salmon species (Merrell and Koski 1979).

Coastal wetlands are also essential for important shellfish like shrimp, blue crabs, oysters and clams. These areas serve as the primary nursery grounds for penaeid shrimp. whose young grow rapidly and reach adulthood here. Scientific studies have recently denonstrated a direct correlation between the amount of coastal marsh and shrimp production (Tumer 1977).

Freshwater fishes also find wetlands important for survival. In fact, most freshwater fishes can be considered wetland-dependent because: (1) many species feed in wetlands or upon wetland-produced food, (2) many fishes use wetlands as nursery grounds and (3) almost all important recreational fishes spawn in the ayuatic portions of wetlands (Peters, et al. 1979). Marshes along Lake Michigan, for example, are spawning grounds for northem pike, yellow perch, carp, smallmouth bass, largemouth bass. bluegill, bullhead and other fishes, including minnows (Jaworski and Raphael 1978). Prized gamefish - muskies and walleyes - may spawn in flooded marshes as well as feed there. Bottomland hardwood forests of the South serve as nursery and feeding grounds for young warmouth and largemouth bass, while adult 


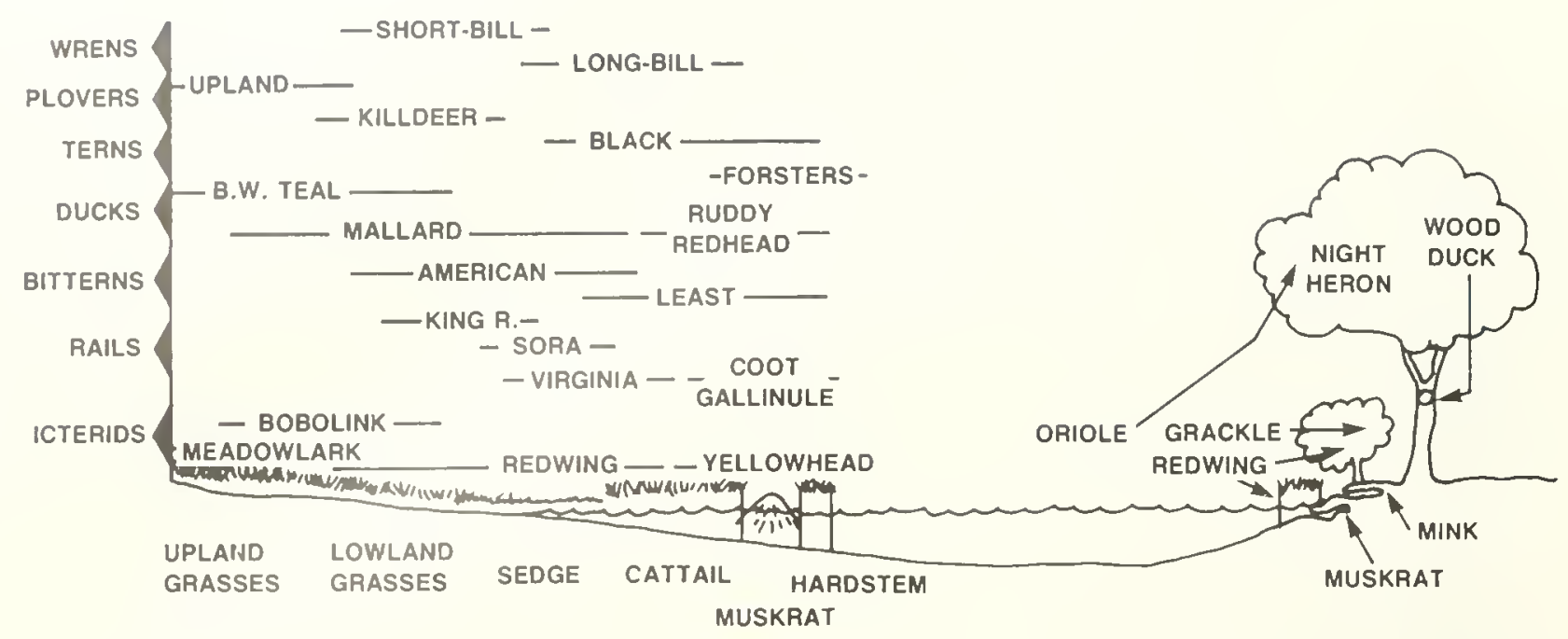

Fig. 13. Welland habitat ulilization by several families of birds (from Weller and Spalcher 1965).

bass feed and spawn in these wetlands. River swamps in Georgia produce 1,300 pounds of tish per acre (Wharton 1970). The bottomlands of the Altamaha River in Georgia are used for spawning hy hickory shad and blueback herring (Wharton and Kitchens 1982). Southern bottomland forested wetlands are also the home of the edible red swamp crayfish ("crawdads") which burrow down to the water table when flooding waters recede (Patrick, et al. 1981). Wetland vegetation along western rivers is important to fishes in many ways, including providing cover, shade for water temperature regulation, and food for aquatic insects which are eaten by fishes.

\section{Waterfowl and Other Bird Habitat}

In addition to providing year-round habitats for resident birds, wetlands are especially important as breeding grounds, overwintering areas and feeding grounds for migratory waterfowl and numerous other birds (Figure 13). Both coastal and inland wetlands serve these valuable functions.

Salt marshes along the Atlantic coast are used for nesting by birds such as black ducks, laughing gulls. Forster's terns, sharp-tailed sparrows, clapper rails, blue-winged teals, willets, marsh hawks, and seaside sparrows. Wading birds like herons and egrets also feed and nest in coastal wetlands. Northeastern salt marshes are prime wintering grounds for black ducks in the Atlantic Flyway. Atlantic coastal marshes are also important feeding and stopover areas for migrating snow geese, peregrine fal- cons, shorebirds, wading hirds and others. Intertidal mudflats along all coasts are principal feeding grounds for migratory shorebirds (e.g.. oystercatchers, plovers and knots), while swallows and chimney swifts can often be seen feeding on flying insects over the marshes.

As one moves upstream into the fresh coastal marshes, other birds can be observed nesting including redwinged blackbirds, long-billed marsh wrens, least bitterns and clapper rails. Nesting birds of freshwater tidal marshes in New Jersey, for example, include these four birds, plus American goldfinch, swamp sparrow. Indigo bunting. common yellowthroat, yellow warbler. Traill's flycatcher, wood duck, green heron, and common gallinule (Hawkins and Leck 1977). Many of these birds utilize non-tidal wetlands as well for nesting.

The Nation's inland wetlands are most noted for waterfowl production, although they also serve as important nesting, feeding and resting areas for other migrating birds (Figures 14 and 15). The Prairie Pothole Region of the Dakotas is the principal breeding area for waterfowl in the United States. Pothole nesters include 15 species, with mallard. pintail and blue-winged teal most abundant (Smith, et al. 1964). Many of these nesters use different types of wetlands for mating and for rearing young. Individual mallard hens may use more than 20 different wetlands during the nesting season (Dwyer, et al. 1979). Besides waterfowl, other birds also nest in these wetlands such as redwinged blackbirds, Brewer's blackbirds, kingbirds. killdeer. spotted sandpipers, sparrows, Wilson's phalaropes and black terns (Johnsgard 1956). Pothole and other inland emergent wetlands also provide important 

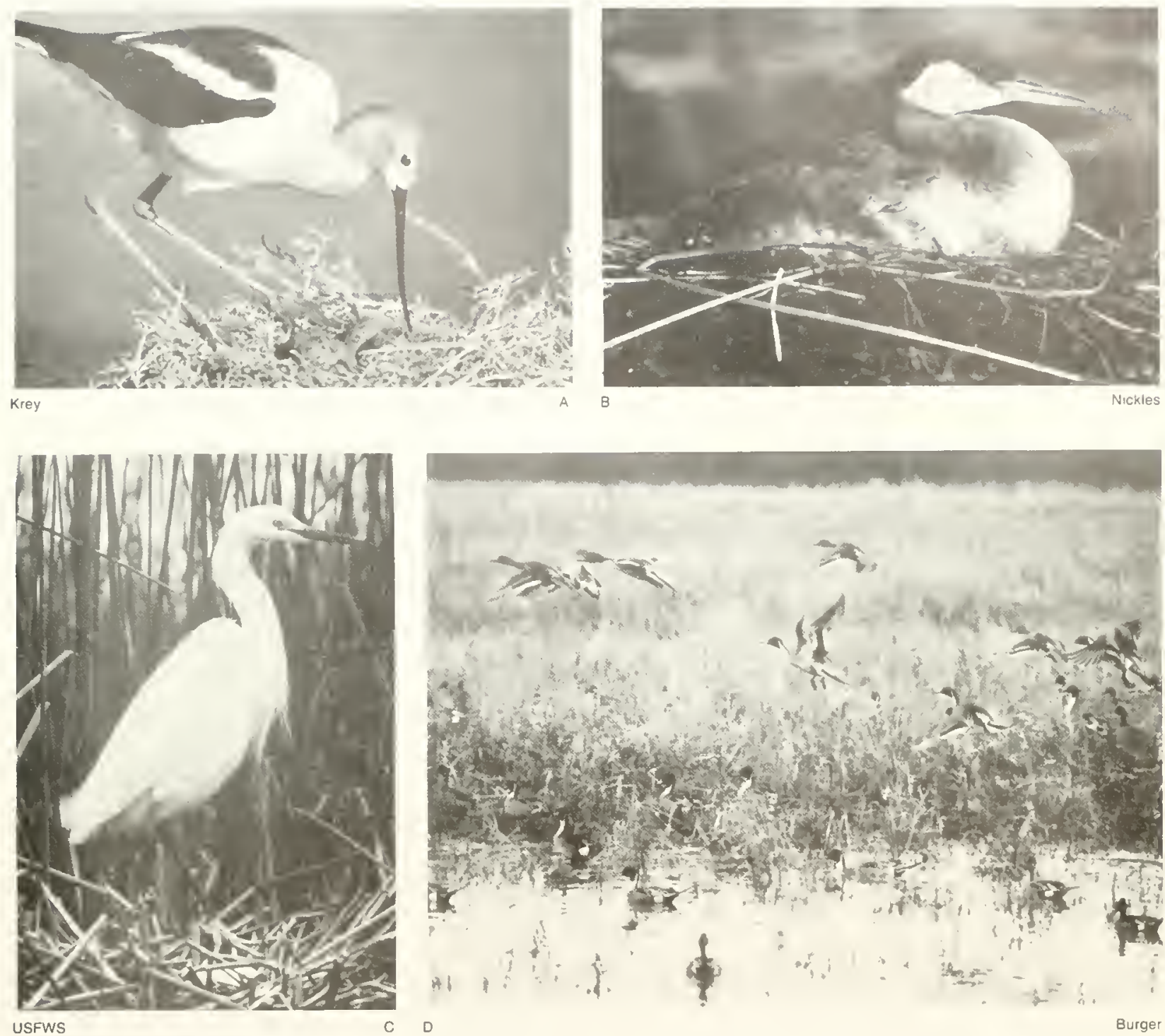

Fig. 14. Migratory birds using wetlands. (a) Amencan avocet turning her eggs, (b) red-necked grebe on nest, (c) snowy egrel on nesl, and (d) puntails feeding.

winter cover and nesting habitat for ring-necked pheasant. In fact, the pheasant population in east-central Wisconsin is directly related to the amount and distribution of wetlands available (Gates and Hale 1974). Playa lake wetlands in the Texas Panhandle are important nesting habitats for pheasants, mourning doves, redwinged blackbirds, and others (Guthery 1981).

Bottomland forested wetlands of the South are primary wintering grounds for North American waterfowl as well as important breeding areas for wood ducks, herons. egrets and white ibises. Wild turkeys even nest in bottomland hardwood forests. Other common bird inhabitants include barred owls. downy and red-bellied woodpeckers, cardinals, pine warblers, wood peewees, yellowthroats and wood thrushes (Wharton and Kitchens 1982).
In the Northeast, red maple swamps are among the most abundant wetland types. A study of breeding birds in eight western Massachusetts swamps revealed a total of 46 breeding species (Swift 1980). Most common breeders include yellowthroat, veerv. Canada warbler, ovenbird, northern waterthrush and gray catbird. The wood duck is another important resident of forested wetlands, primarily in the eastern half of the U.S., where it nests in cavities of dead trees or in man-made nesting boxes.

In the West, riparian forested wetlands along rivers are valuable bird nesting and migration stopover areas. Wauer (1977) found 94 avian species nesting in riparian vegetation of the Rio Grande, including mourning doves. 


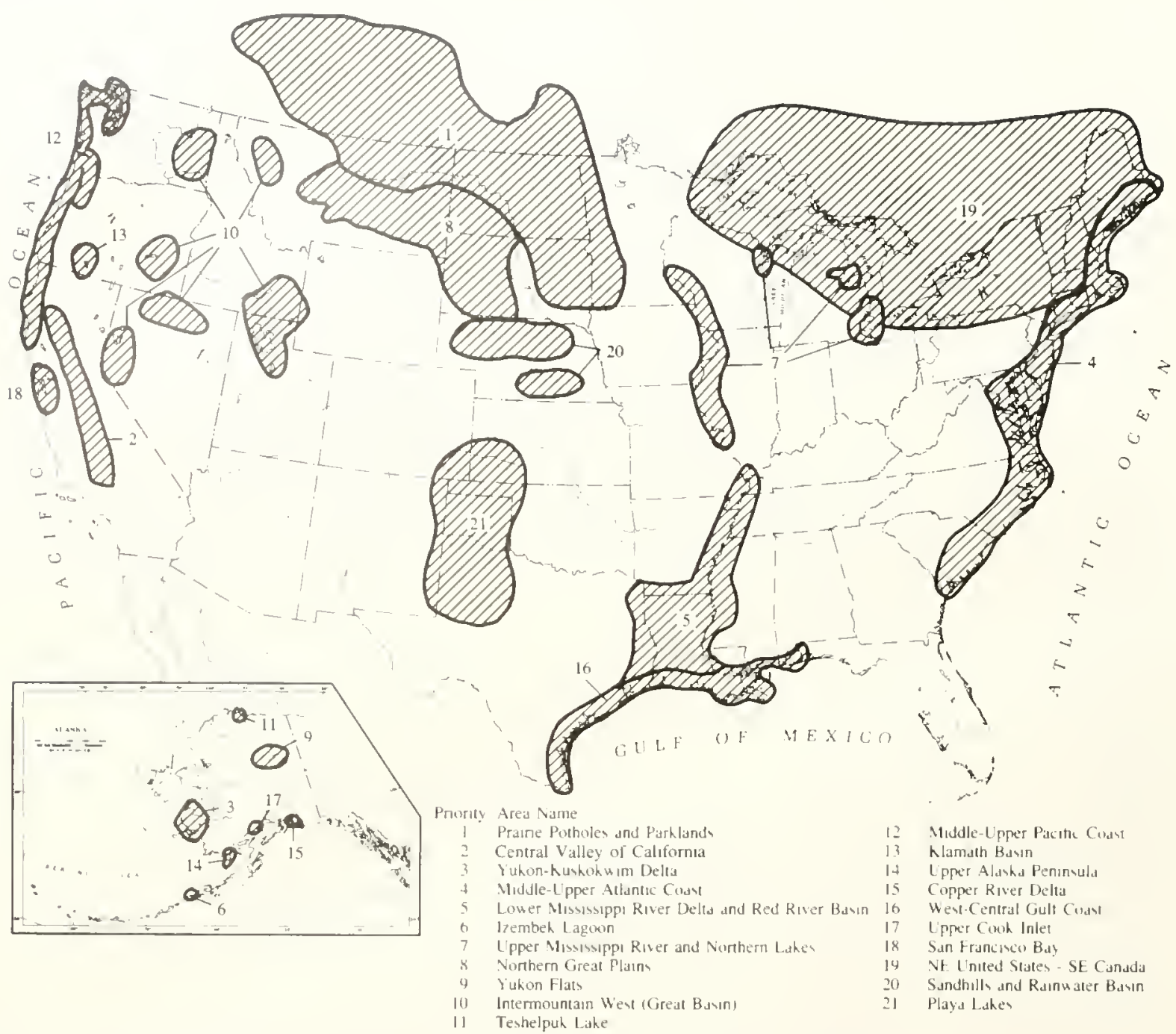

Fig. 15. Waterfowl habitat areas of major national concern (from U.S. Fish and Wildlife Service 1984).

verdins, northern orioles and brown-headed cowbirds. These riparian wetlands were very inportant to migrating birds in the spring and fall. In Arizona, the yellow-billed cuckoo and blue-throated hummingbird are restricted to cottonwood-ivillow forested wetlands (Brown, et al. 1977). Riparian wetlands may be more important to migrating birds in arid regions than in more humid areas. The availability of food, water, cover, and suitable northsouth routing strongly influence migrants (Wauer 1977).

Alaskan and other tundra wetlands are prime breeding grounds for most shorebirds such as sandpipers, plovers and their relatives. Nearly the entire Pacific Flyway populations of the cackling Canada goose and the whitefronted goose nest in Alaska's Yukon-Kuskokwim Delta. Alaska is also the most important production area for pintail in the U.S. (U.S. Fish and Wildlife Service 1984). During droughts in the Prairie Pothole Region, Alaska's wetlands are heavily used by North American waterfowl for nesting.
Hawaii's wetlands are especially important to endangered birds. The Hawaiian stilt, Hawaiian coot, Hawaiian gallinule, and Hawaiian duck depend on wetlands for survival.

Wetlands are, therefore, crucial for the existence of many birds, ranging from waterfowl and shorebirds to songbirds. Some spend their entire lives in wetland environments, while others primarily use wetlands for nesting, feeding or resting.

\section{Furbearer and Other Wildlife Habitat}

If a fur trapper is asked about the value of wetlands, he is likely to reply that they produce furbearers, like muskrats, beavers and nutria. Muskrats are the most wide ranging of the three, inhabitating both coastal and inland marshes throughout the country. By contrast, beavers tend to be restricted to inland wetlands, with nutria limit- 

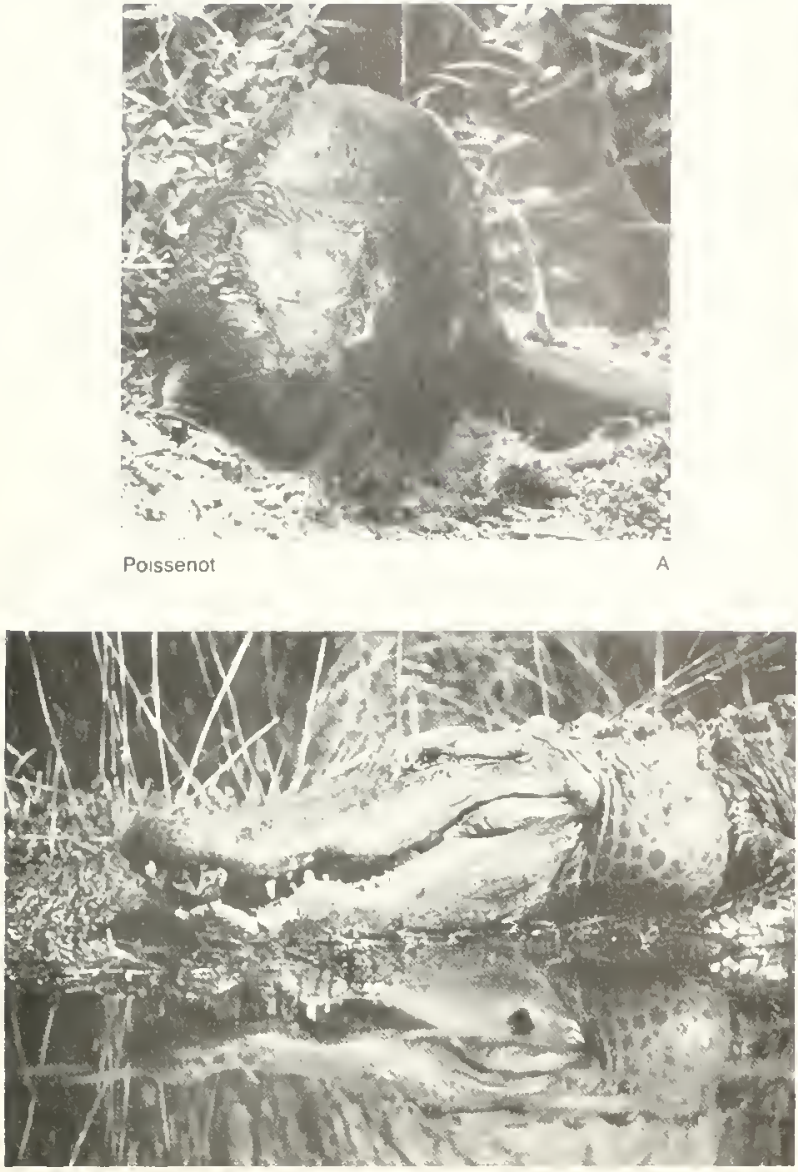

Goeke
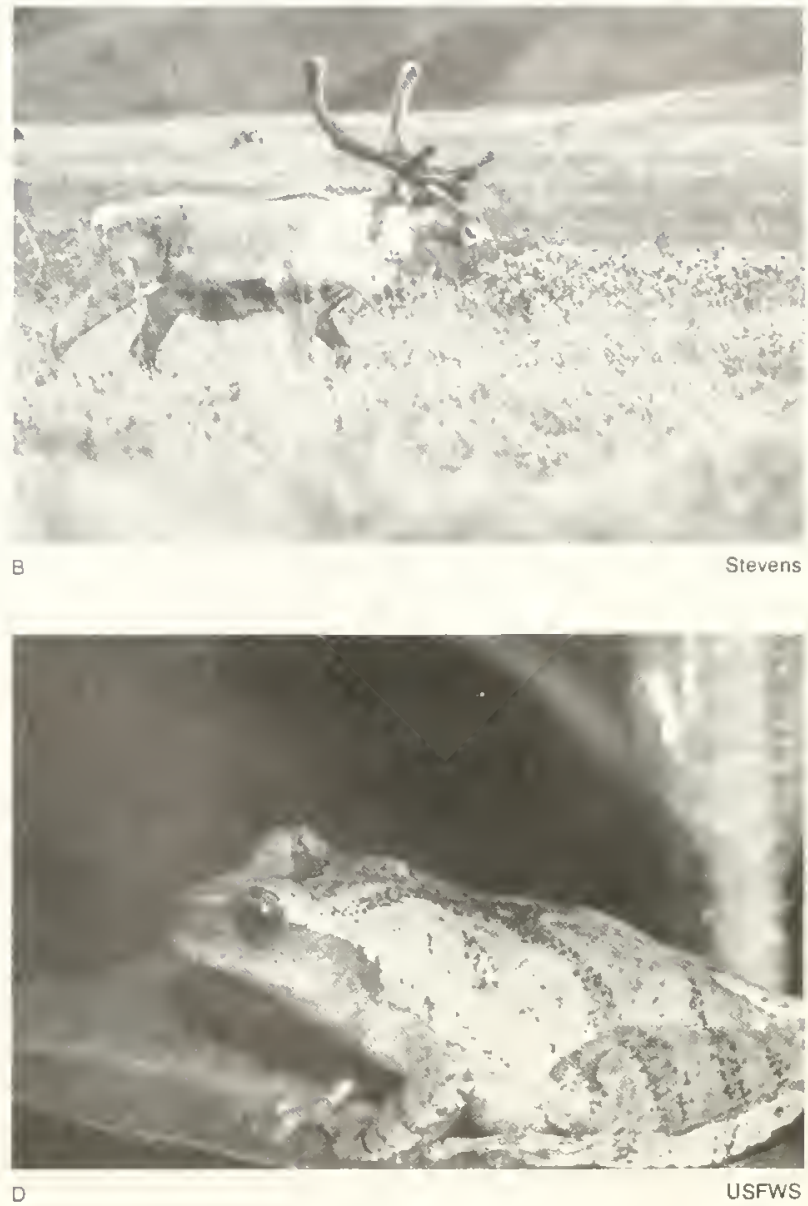

USFWS

Fig. 16. Wetlands are important to many other wildlife, (a) beaver, (b) caribou, (c) alligator, and (d) spring peeper.

ed to coastal wetlands of the South. Other wetland-utilizing furbearers include otter, mink, raccoon, skunk and weasels. Other mammals also frequent wetlands, such as marsh and swamp rabbits, numerous mice, bog lemmings and shrews. Larger mammals may also be observed. Black bears find refuge and food in forested and shrub wetlands of northeastern Pennsylvania and western Massachusetts, for example. In northern states, white-tailed deer depend on white cedar and other evergreen swamps for winter shelter and food. By contrast, the extensive wetlands of Alaska's North Slope are used as summer range and calving areas by caribou.

Other forms of wildlife make their homes in wetlands (Figure 16). Turtles, reptiles, and amphibians are important residents. Turtles are most common in freshwater marshes and ponds. The more important ones are the painted, spotted. Blanding's, map, mud, pond, musk and snapping turtles (Clark 1979). The endangered Plymouth red-bellied turtle and bog turtle are also wetland-dependent (Williams and Dodd 1979). Along the coast, the diamond-backed terrapin is a common inhabitant of salt marshes, while young loggerhead turtles spend some time in estuaries after hatching before going out to sea.

The largest reptiles occurring in the United States the American alligator and the American crocodile live in wetlands. The crocodile, an endangered species, is now only found in mangroves and coastal waters of Florida Bay, while the alligator occurs from Florida north to North Carolina and west to Texas. The alligator lives in both brackish and freshwater wetlands, but is most abundant in the latter. Alligators create "gator holes" in the Everglades, which persist through the dry season. Fishes and invertebrates concentrate in these holes which make them easy prey for birds and other animals. Gator holes with their abundance of food are important to the breeding success of birds like the wood ibis (Williams and Dodd 1979).

Many snakes inhabit wetlands, with water snakes being most abundant throughout the U.S. (Clark 1979). Other important wetland snakes include cottonmouth 
moccasın, garter, queen, mud and swanı snakes. In bottomland wetlands of the South. copperheads and canebrake rattlesnakes can be found as well as northern brown. garter, rough green and rat snakes (Wharton and Kitchens 1982). The San Francisco garter snake, an endangered species, also requires wetlands for survival (Williams and Dodd 1979).

Nearly all of the approximately 190 species of amphibians in North America are wetland-dependent, at least for breeding (Clark 1979). Every freshwater wetland in the U.S., except in the Arctic tundra, probably has some Irogs. Common frogs include the bull, green, leopard, mink, pickerel, wood and chorus Irogs and spring peepers. Many salamanders use temporary ponds or wetlands for breeding. although they spend most of the year in uplands. Numbers of amphibians, even in small wetlands, can be astonishing. For example. 1,600 salamanders and 3.800 frogs and toads were found in a small gum pond (less than 100 feet wide) in Georgia (Wharton 1978).

\section{Environmental Quality Values}

Besides providing homes for fish and wildlife, wetlands play a less conspicuous but nonetheless important role in maintaining high environmental quality, especially in aquatic habitats. They do this in a number of ways, including purifying natural waters by removing nutrients, chemical and organic pollutants, and sediment and producing food which supports aquatic life.

\section{Water Quality Improvement}

Wetlands help maintain good water quality or improve degraded waters in several ways: (1) removing nutrients, (2) processing chemical and organic wastes, and (3) reducing sediment loads of water. Wetlands are particularly good water filters because of their location between land and water. Thus, they can both intercept runoff from land before it reaches the water and help filter nutrients, wastes and sediment from flooding waters. Clean waters are important to man as well as to aquatic life.

First. wetlands remove nutrients, especially nitrogen and phosphorus, from flooding waters for plant growth and help prevent eutrophication or overenrichment of natural waters. It is, however, possible to overload a wetland and thereby reduce its ability to perform this function. Every wetland has a limited capacity to absorb nutrients and individual wetlands differ in their ability to do so.

Wetlands have been shown to be excellent removers of waste products from water. In fact, certain wetland plants are so efficient at this task that some artificial waste treatment systems are using these plants. For example, the Max Planck Institute of Germany has a patent to create such systems, where a bulrush is the primary waste removal agent (Sloey, et al. 1978).

Numerous scientists have proposed that certain types of wetlands be used to process domestic wastes. Some wetlands are already used for this purpose. The Brillion Marsh in Wisconsin has received domestic sewage since 1923. This cattail marsh on the average removed $80 \%$ of biological oxygen demand, $86 \%$ of coliform bacteria, $51 \%$ of nitrates, $40 \%$ of chemical oxygen demand, $4+\%$ of turbidity, $29 \%$ suspended solids and $13 \%$ of total phosphorus. After passing through Brillion Marsh, there was a significant improvement in water quality (Boto and Patrick 1979).

Perhaps the hest example of the importance of wetlands for water quality improvement is Tinicum Marsh (Grant and Patrick 1970). Tinicum Marsh is a 512-acre freshwater tidal marsh lying just south of Philadelphia. Pennsylvania (Figure 17). Three sewage treatment plants discharge treated sewage into marsh waters. On a daily basis, it was shown that this marsh removes from flooding waters: 7.7 tons of biological oxygen demand, 4.9 tons of phosphorus, 4.3 tons of ammonia, and 138 pounds of nitrate. In addition. Tinicum Marsh adds 20 tons of oxygen to the water each day.

Swamps also have the capacity for removing water pollutants. Bottomland forested wetlands along the $\mathrm{Al}$ covy River in Georgia filter impurities from flooding waters. Human and chicken wastes grossly pollute the river upstream. but after passing through less than 3 miles of swamp, the river's water quality is significantly improved. The value of the 2,300-acre Alcovy River Swamp for water pollution control was estimated at \$1 million per year (Wharton 1970).

Wetlands play a valuable role in reducing turbidity of flooding waters. This is especially important for aquatic life and for reducing siltation of ports, harbors, rivers and reservoirs. Removal of sediment load is also valuable because sediments often transport absorbed nutrients. pesticides, heavy metals and other toxins which pollute our Nation's waters (Boto and Patrick 1979). Depressional wetlands should retain all of the sediment entering them (Novitski 1978). In Wisconsin, watersheds with $40 \%$ coverage by lakes and wetlands had $90 \%$ less sediment in water than watersheds with no lakes or wetlands (Hindall 1975). Creekbanks of salt marshes typically support more productive vegetation than the marsh interior. Deposition of silt is accentuated at the water-marsh interface. where vegetation slows the velocity of water causing sediment to drop out of solution. In addition to improving water quality, this process adds nutrients to the creekside marsh which leads to higher plant productivity (Delaune, et al. 1978).

The U.S. Army Corps of Engineers has investigated the use of marsh vegetation to lower turbidity of dredged disposal runoff and to remove contaminants. In a 50-acre impoundment near Georgetown, South Carolina, after passing through about 2.000 feet of marsh vegetation, the effluent turbidity was similar to that of the adjacent river 


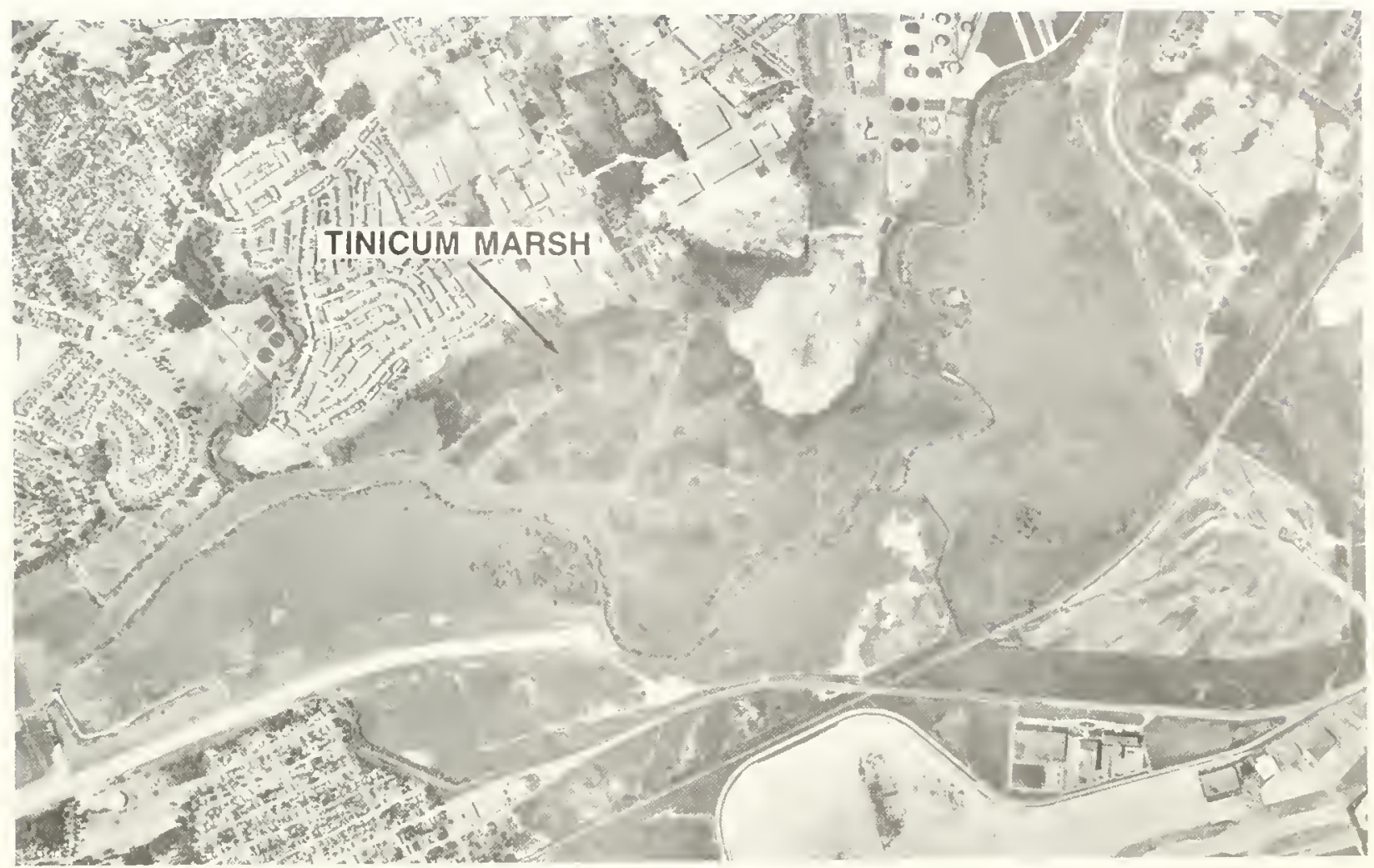

Fig. 17. Aerial view of Tinicum Marsh near Philadelphia, Pennsylvania. This marsh is particularly valuable for improving water quality in an urban environmenl.

(Lee, et al. 1976). Wetlands have also been proven to be good filters of nutrients and heavy metal loads in dredged material disposal effluents (Windom 1977).

\section{Aquatic Productivity}

Wetlands are among the most productive ecosystems in the world and they may be the highest, rivaling our best cornfields (Figure 18). Wetland plants are particularly efficient converters of solar energy. Through photosynthesis, plants convert sunlight into plant material or biomass and produce oxygen as a by-product. This biomass serves as food for a multitude of animals, both aquatic and terrestrial. For example, many waterfowl depend neavily on seeds of marsh plants, while muskrat eat cattail tubers and young shoots. Moose, caribou, black bears and brown bears graze on marsh plants in Alaska (Crow and Macdonald 1979).

Although direct grazing of wetland plants is generally limited, their major food value is reached upon death when plants fragment to form detritus. This detritus forms the base of an aquatic food web which supports higher consumers, like commercial fishes (Figure 19). This relationship is especially well-documented for coast- al areas. Animals, like shrimp, snails, clams, worms. killifish and mullet, eat detritus or graze upon the bacteria. fungi, diatoms and protozoa growing on its surfaces (Crow and Macdonald 1979: de la Cruz 1979). Many of these animals are the primary food for commercial and recreational fishes. Salmon are linked with wetlands and detritus. Juvenile salmon in Puget Sound. Washington, feed mainly on salt marsh midge larvae, which subsist on detritus (Crow and Macdonald 1979). Detritus from wetland vegetation along western rivers feeds aquatic insects important to the diet of resident fishes. Thus, wetlands can be regarded as the farmlands of the aquatic environment where great volumes of food are produced annually. The majority of non-marine aquatic animals depend, either directly or indirectly, on this food source.

\section{Socio-Economic Values}

The more tangible benefits of wetlands to mankind may be considered socio-economic values and they include flood and storm damage protection. erosion control, water supply and groundwater recharge, harvest of natural products, livestock grazing and recreation. Since these values provide either dollar savings or financial profit, they are more easily understood by most people. 


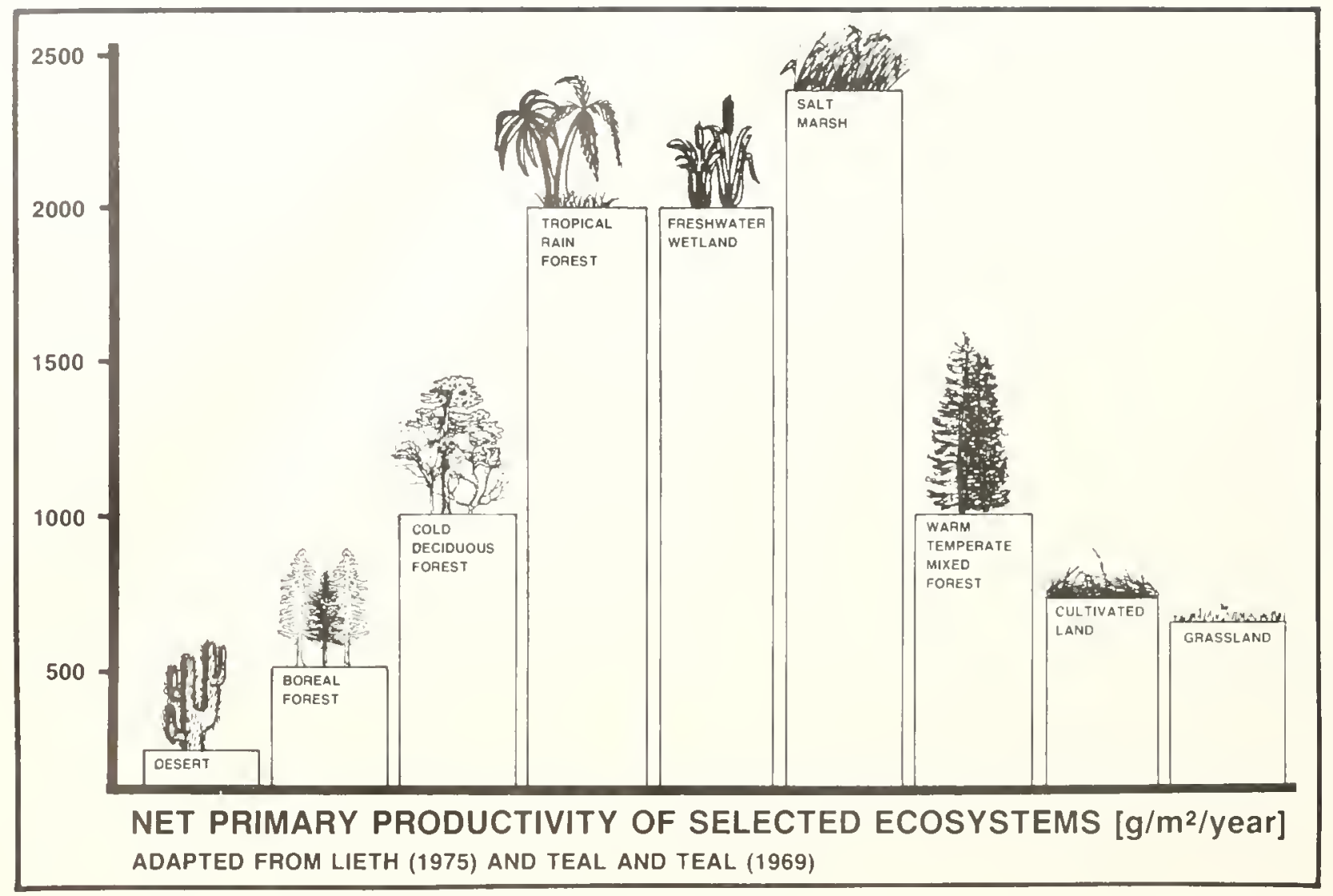

Fig. 18. Relative productivity of wetland ecosystems in relation to others (from Newton 1981).

WETLAND PLANTS $\quad$ ESTUARINE WATERS

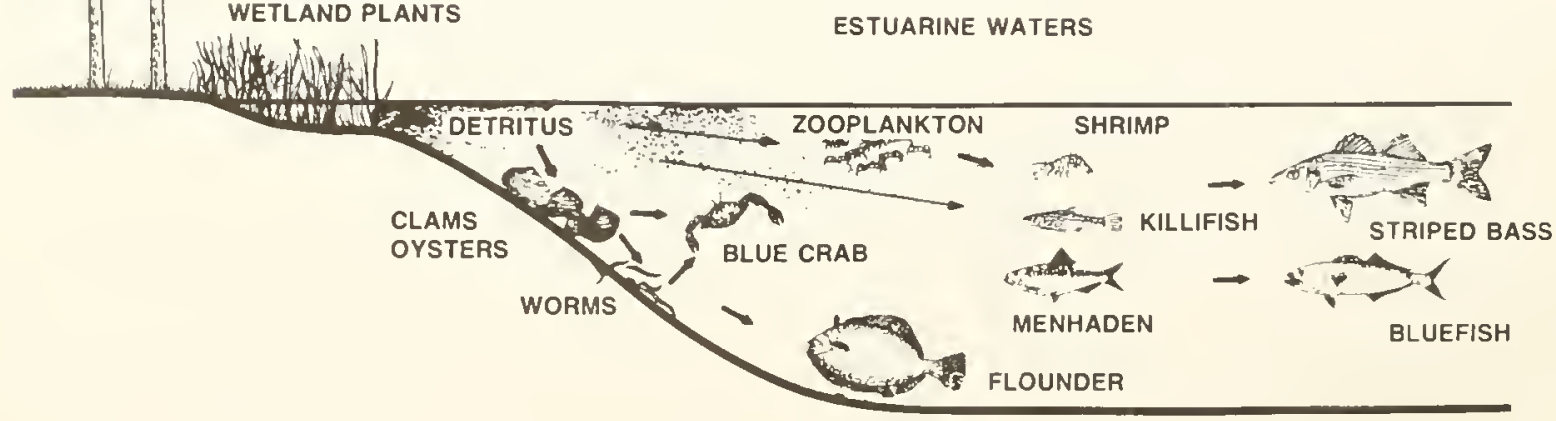

Fig. 19. Simplified food pathways from estuarine wetland vegetation to commercial and recreational fishes 


\section{Flood and Storm Damage Protection}

In their natural condition, most wetlands serve to temporarily store flood waters, thereby protecting downstream property owners from flood damage. After all, such flooding has been the driving force in creating these wetlands. This flood storage function also helps to slow the velocity of water and lower wave heights, which reduces the water's erosive potential. Rather than having all flood waters flowing rapidly downstream and destroying private property and crops. wetlands slow the flow of water, store it for some time and slowly release stored waters downstream (Figure 20). In this way, flood peaks of tributary streams are desynchronized and Hood waters do not all reach the mainstem river at the same time. This function becomes increasingly important in urban areas, where development has increased the rate and volume of surface water runoff and the potential for flood damage.

In 1975, 107 people were killed by flood waters and potential property damage for the year was estimated to be $\$ 3.4$ billion (U.S. Water Resources Council 1978). Almost half of all flood damage is suffered by agriculture as crops and livestock are destroyed and productive land is covered by water or lost to erosion. Approximately 134 million acres of the conterminous United States have severe flooding problems. Of this, 2.8 million acres are urban land and 92.8 million acres are agracultural land (U.S. Water Resources Council 1977). Many of these flooded farmlands are wetlands or previously drained wetlands.

Although regulations required by the Federal Insurance Administration may help reduce flood losses from urban land, agricultural losses are expected to remain at present levels or increase as more wetlands are put into crop production. Protection of wetlands is, therefore, an important means of minimizing llood damages in the future.

The U.S. Army Corps of Engineers has recognized the value of wetlands for Hood storage in Massachusetts. In the early 1970's, the New England Division considered various alternatives to providing flood protection in the lower Charles River watershed near Boston, including: (1) 55,000 acre-foot reservoir. (2) extensive walls and dikes, and (3) perpetual protection of 8.500 acres of wetlands (U.S. Army Corps of Engineers 1976). If $40 \%$ of the Charles River wetlands were destroyed. flood damages would increase by at least $\$ 3$ million annually. Loss of all basin wetlands would cause an average annual flood damage cost of $\$ 17$ million (Thibodeau and Ostro 1981 ). The Corps concluded that wetlands protection - "Natural Valley Storage" — was the least-cost solution to flooding problems. In 1983, they completed wetland acquisition in the Charles River basin.

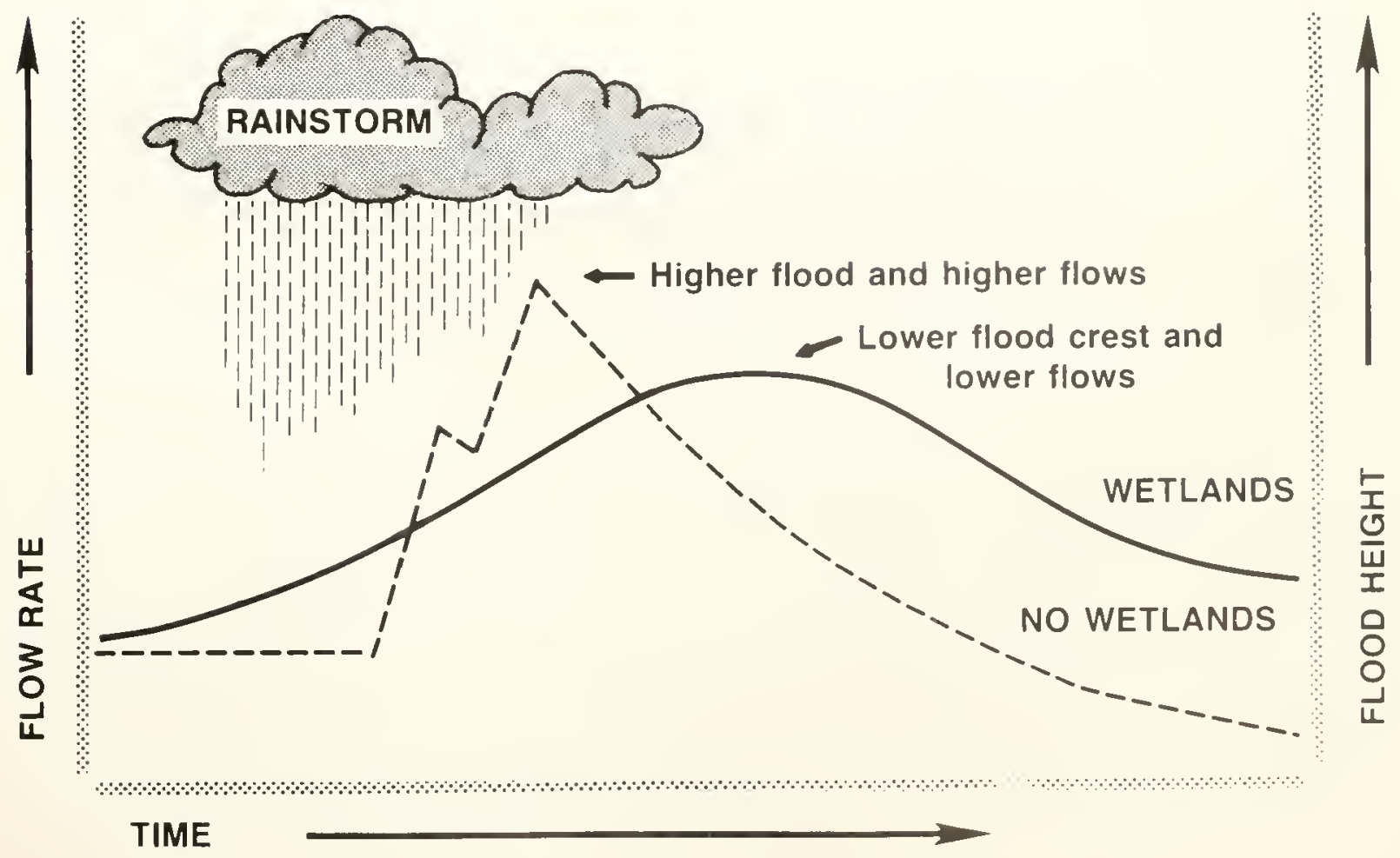

Fig. 20. Wetland value in reducing flood crests and flow rates after rainstorms (adapted from Kusler 1983) 


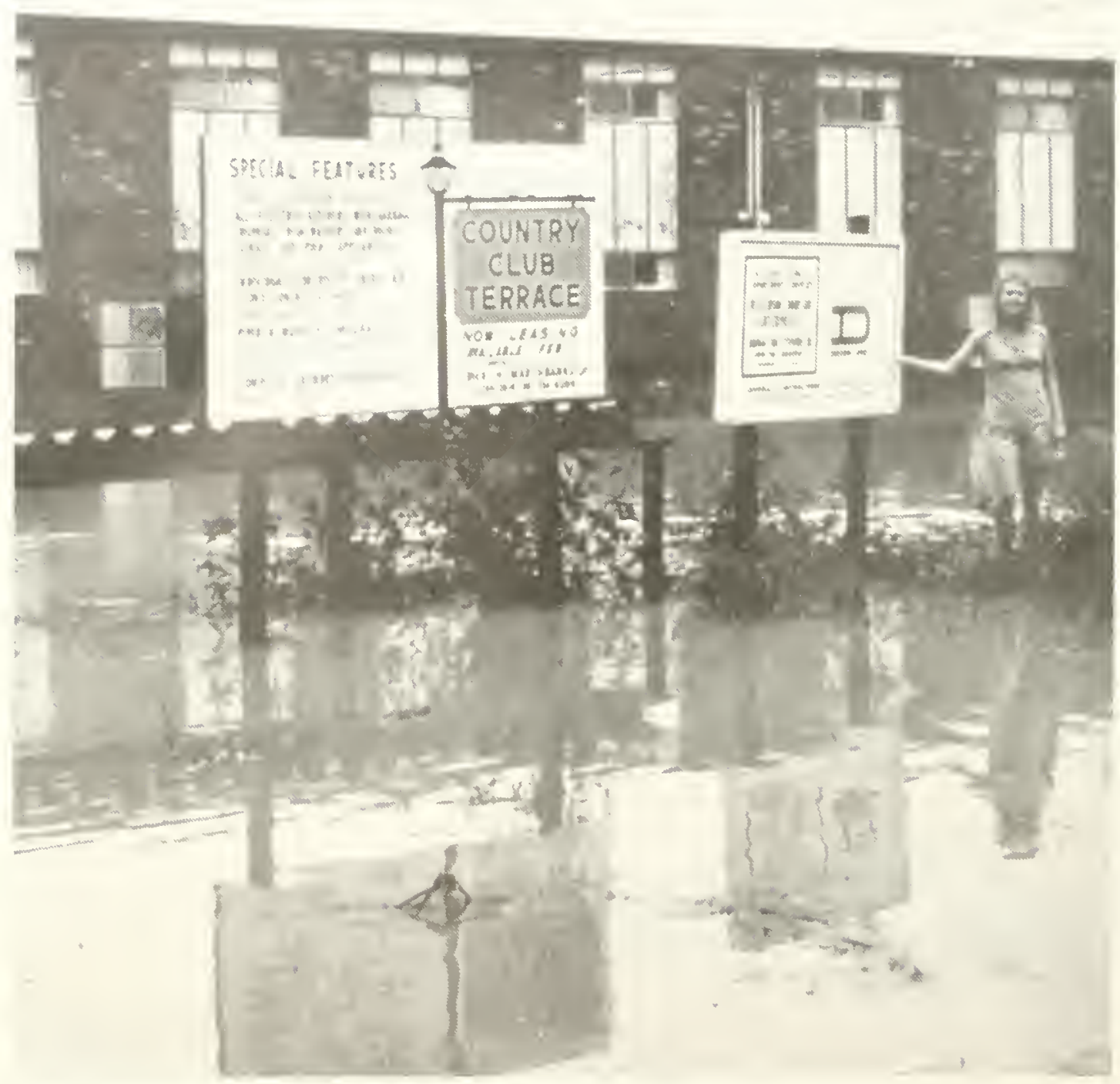

Fig. 21. Wetland drainage and filling increase the polential for damaging floods.

This flood storage value of wetlands has also been reported for other areas. In eastern Pennsylvania, the 1955 floods washed out all but two bridges along one stream; the remaining bridges lay immediately downstream of the Cranberry Bog (Goodwin and Niering 1975). A Wisconsin study projected that floods may be lowered as much as $80 \%$ in watersheds with many wetlands compared with similar basins with little or no wetlands (Novitski 1978). Pothole wetlands in the Devils Lake basin of North Dakota store nearly $75 \%$ of the total runoff (Ludden, et al. 1983).

Recent studies at National Wildlife Refuges in North Dakota and Minnesota have demonstrated the role of wetlands in reducing streamflow. Inllow into the Agassiz National Wildlife Refuge and the Thief River Wildlife Management Area was 5,000 cubic feet per second (cfs), while outflow was only 1,400 cfs. Storage capacity of those areas reduced flood peaks at Crookston, Minnesota, by 1.5 feet and at Grand Forks, North Dakota, by 0.5 feet (Bernot 1979). Drainage of wetlands was the most important land-use practice causing flood problems in a North Dakota watershed (Malcolm 1978; Malcolm 1979). Even northern peat bogs reduce peak rates of streamflow from snow melt and heavy summer rains (Verry and Boelter 1979). Destruction of wetlands through floodplain development and drainage has been partly responsible for recent major flood disasters throughout the country (Figure 2]).

Besides reducing flood levels and potential damage. wetlands may buffer the land from storm wave damage. Mangrove swamps are so effective in this regard that the Federal Insurance Administration's regulations state that 
insured communities shall prohibit mangrove destruction or lose Federal flood insurance. Extensive mangrove stands protect many coastal communities in Florida. Past destruction of these wetlands for resort housing developments has increased the potential for disaster. Other coastal wetlands and forested wetlands along lakes and large rivers may function similarly.

\section{Erosion Control}

Located between watercourses and uplands, wetlands help protect uplands Irom erosion. Wetland vegetation can reduce shoreline erosion in several ways, including: (1) increasing durability of the sediment through binding with its roots, (2) dampening waves through liction and (3) reducing current velocity through friction (Dean 1979). This process also helps reduce turbidity and thereby improves water quality.

Obviously, trees are good stabilizers of river banks Their roots bind the soil making it more resistant to erosion, while their trunks and branches slow the flow of flooding waters and dampen wave heights. The banks of some rivers have not been eroded for 100 to 200 years due to the presence of trees (Leopold and Wolman 1957; Wolman and Leopold 1957; Sigafoos 1964). Among the grass or grass-like plants, bulrushes and reed have been regarded as the best at withstanding wave and current action (Kadlec and Wentz 1974; Seibert 1968). While most wetland plants need calm or sheltered water for establishment, they will effectively control erosion once established (Kadlec and Wentz 1974: Garbisch 1977).

Wetland vegetation has been successfully planted to reduce erosion along U.S. waters. Willows, alders, ashes, cottonwoods, poplars, maples and elms are particularly good stabilizers (Allen 1979). Successful emergent plants include reed canary grass, reed. cattail, and bulrushes in freshwater areas (Hoffman 1977). Along the Atlantic and Gulf coasts, smooth cordgrass and mangroves have been quite effective (Woodhouse, et al. 1976: Lewis and Thomas 1974).

\section{Water Supply and Groundwater Recharge}

Most wetlands are areas of groundwater discharge and some may provide sufficient quantities of water for public use. In Massachusetts, $40 \%$ to $50 \%$ of wetlands nray be valuable potential sources of drinking water. At least 60 municipalities in the state have public wells in or very near wetlands (Motts and Heeley 1973). Urban development of wetlands and subsequent groundwater withdrawals have caused saltwater intrusion into aquifers in many coastal areas. Prairie pothole wetlands store water which is important for wildlife and may be used for irrigation and livestock watering by farmers during droughts (Leitch 1981). These situations may hold true for many other states and wetland protection could be instrumental in solving current and future water supply problems.

There is considerable debate over the role of wetlands in groundwater recharge. Recharge potential of wetlands varies according to numerous factors, including wetland type. geographic location. season. soil type, water table location and precipitation. Depressional wetlands like cypress domes in Florida and prairie potholes in the Dakotas may contribute to groundwater recharge (Odum, et al. 1975; Stewart and Kantrud 1972; Winter and Carr 1980). Floodplain wetlands also may do this through overbank water storage (Mundorff 1950, Klopatek 1978). Marshes and swamps along the Ipswich River in Massachusetts occasionally operate as recharge areas (U.S. Department of the Interior 1962).

\section{Harvest of Natural Products}

A variety of natural products are produced by wetlands, including timber, fish and shellfish, wildlife, peat. cranberries, blueberries, and wild rice. Wetland grasses are hayed in many places for winter livestock feed. During other seasons, livestock graze directly in wetlands across the country. These and other products are harvested by man for his use and provide a livelihood for many people.

In the 49 continental states, an estimated 82 million acres of commercial forested wetlands exist (Johnson 1979). These forests provide timber for such uses as homes, furniture, newspapers and firewood. Most of these forests lie east of the Rockies, where trees like oak. gum, cypress, elm, ash and cottonwood are most important. The standing value of southern wetland forests alone is $\$ 8$ billion. These southern forests have been harvested for over 200 years without noticeable degradation, thus they can be expected to produce timber for many years to come, unless converted to other uses. Conversion of bottomland forests in the Mississippi Delta to agricultural fields (e.g., soybeans) has reduced these wetlands by 75\% (Giulio 1978: MacDonald, et al. 1979: Frederickson 1979).

Wetlands also produce fish and wildlife for man's use. Commercial fishermen and trappers make a living from these resources (Figure 22). From 1956 to 1975, about $60 \%$ of the U.S. commercial landings were fishes and shellfishes that depend on wetlands (Peters, et al. 1979). Major commercial species associated with wetlands are menhaden, salmon, shrimp, blue crab and alewife from coastal waters and catfish, carp and buffalo from inland areas. Furs from beaver, muskrat, mink, nutria, and otter yielded roughly $\$ 35.5$ million in 1976 (Demms and Pursley 1978). Louisiana is the largest fur-producing state and nearly all furs come from wetland animals. Freshwater wetlands provide a greater value of fur harvest per acre than estuarine wetlands (Chabreck 1979). 


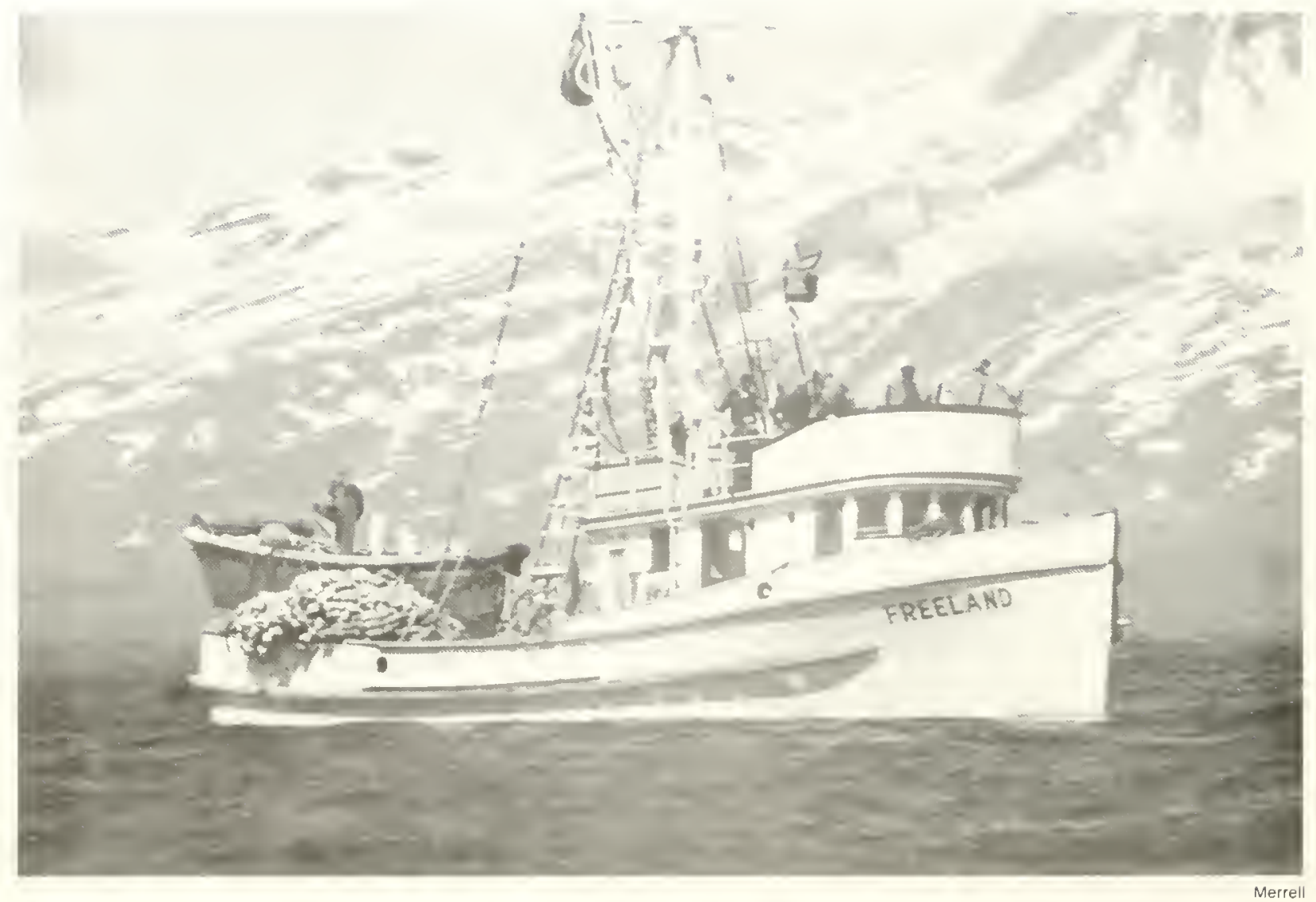

Fig.22. Estuarine-dependent fishes, like salmon, provide the majority of the commercial fisheries landings in the United States.

Many wetlands produce peat which is used mainly for horticulture and agriculture in the United States. Over 52 million acres of peat deposits exist in the country. Five states account for more than $75 \%$ of the peat production: Michigan. Florida, Illinois, Indiana and New York (Carpenter and Farmer 1981). That is particularly interesting, since our largest peat reserves are in Alaska and Minnesota (Farnham 1979). For centuries, peat has been used as a major fuel source in Europe. Recent shortages in other fuels, particularly oil and gas, have increased attention to wetlands as potential fuel sources. Unfortunately, peat mining destroys wetlands and most of their associated values.

\section{Recreation and Aesthetics}

Many recreational activities take place in and around wetlands. Hunting and fishing are popular sports. Waterfowl hunting is a major activity in wetlands, but big game hunting is also important locally. In 1980,5.3 million people spent $\$ 638$ million on hunting waterfowl and other migratory birds (U.S. Department of the Interior and Department of Commerce 1982). Saltwater recreational fishing has increased dramatically over the past 20 years, with half of this catch represented by wetland-associated species. Moreover, nearly all freshwater fishing is dependent on wetlands (Figure 23). In 1975 alone, sportfishermen spent $\$ 13.1$ billion to catch wetland-dependent fishes (Peters, et al. 1979).

Other recreation in wetlands is largely non-consumptive and involves activities like hiking, nature observation and photography, swimming, boating, and ice-skating. Many people simply enjoy the beauty and sounds of nature and spend their leisure time walking or boating in or near wetlands observing plant and animal life. The aesthetic value of wetlands is extremely difficult to evaluate or place a dollar value upon. Nonetheless, it is a very important one because in 1980 alone, 28.8 million people ( $17 \%$ of the U.S. population) took special trips to observe, photograph or feed wildlife (Figure 24). Moreover, about $47 \%$ of all Americans showed an active interest in wildlife around their homes (U.S. Department of the Interior and Department of Commerce 1982). 


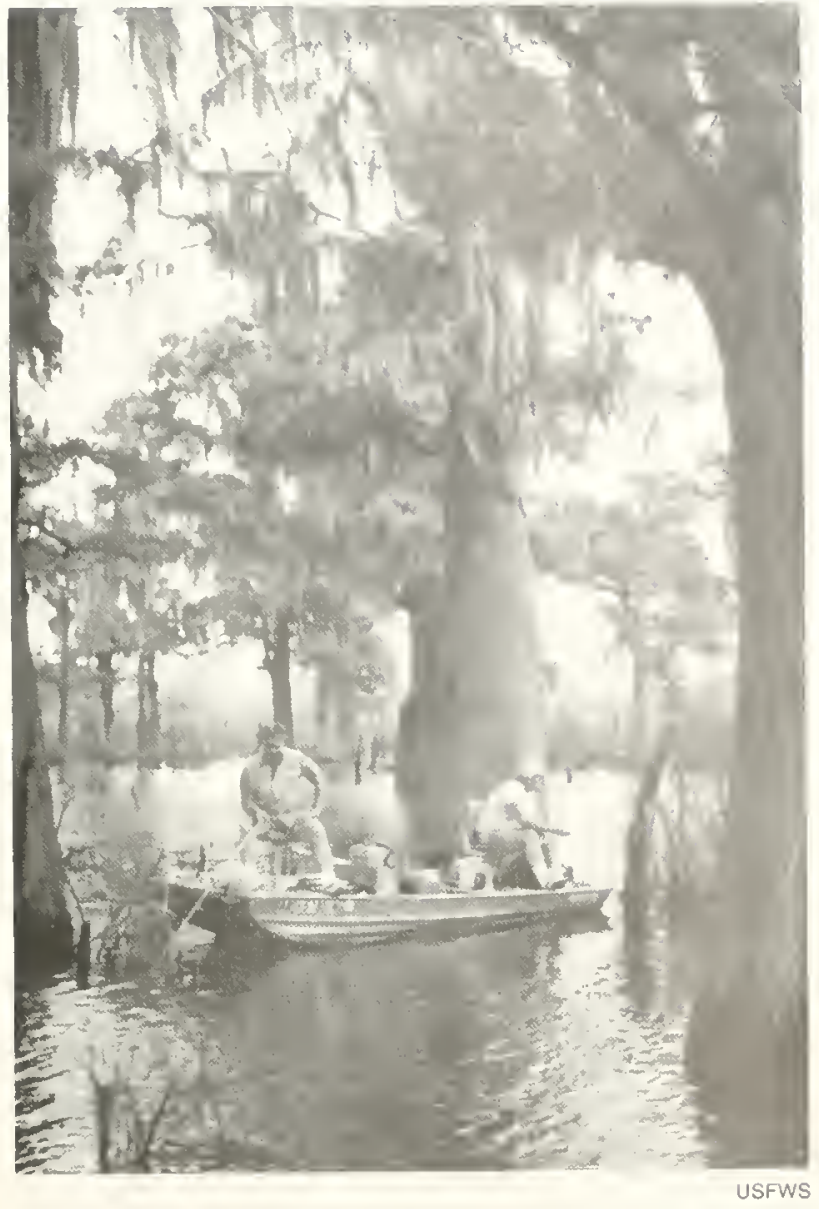

\section{Summary}

Marshes, swamps and other wetlands are an asset to society in their natural state. They provide numerous products for man's use and consumption, protect private property and provide recreational and aesthetic appreciation opportunities. Destruction or alteration of wetlands eliminates or minimizes these values. Drainage of wetlands, for example. eliminates all the beneficial effects of the marsh on water quality and directly contributes 10 flooding problems (Lee, et al. 1975). While the wetland landowner can derive financial profit from some of the values mentioned, the general public receives the vast majority of wetland benefits through flood and storm damage control, erosion control. water quality improvement and fish and wildlife resources. It is, therefore, in the public's best interest to protect wetlands to preserve these values for themselves and future generations.

Fig. 23. Wetlands provide opportunities for recreational fishing

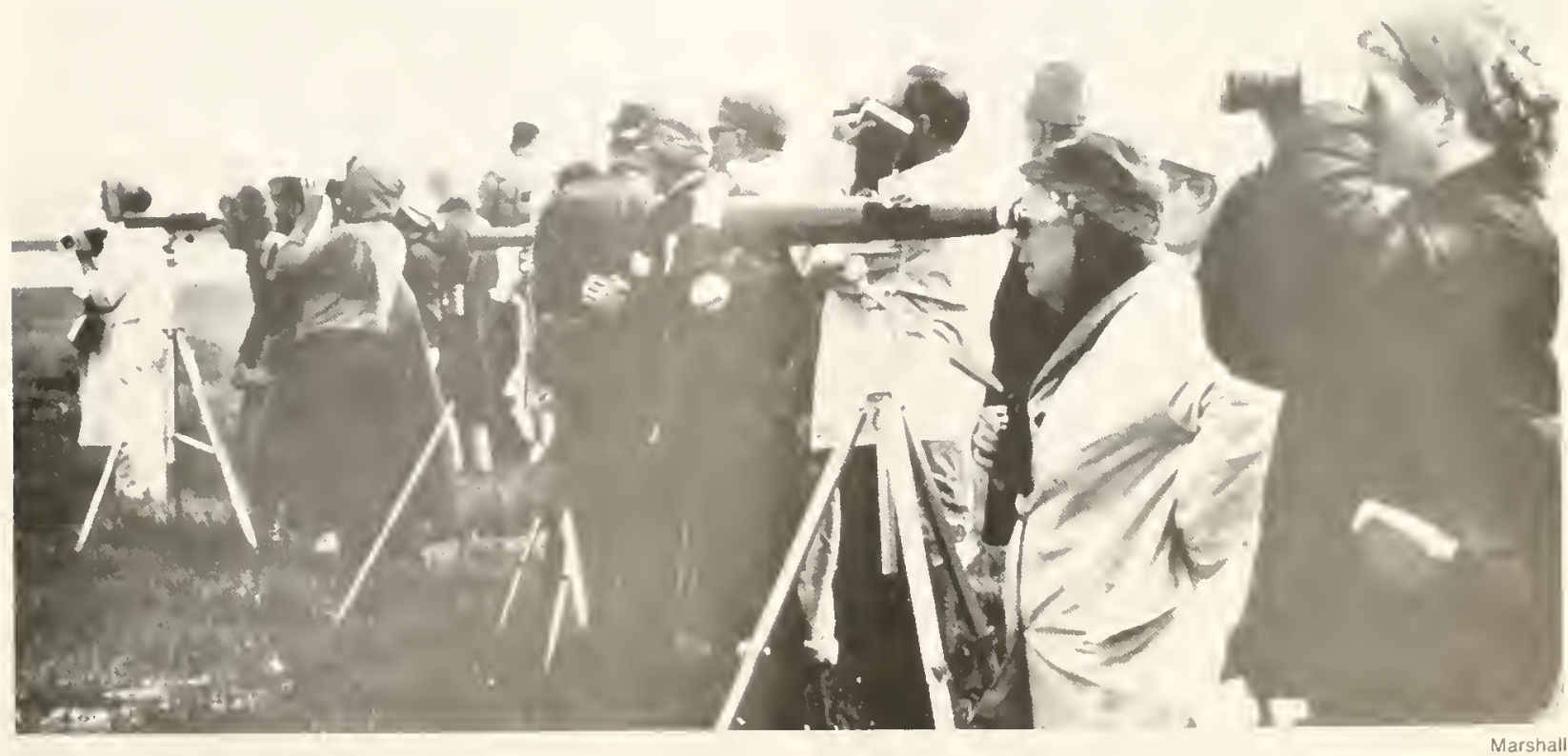

Fig. 24. Many Americans enjoy watching birds in and around wetlands. 


\section{References}

Allen, H.H. 1979 Role of wetland plants in erosion control of ripanan shorelines. In: P.E. Greeson, et al. Wetland Functions and Values: The State of Our Understanding. Amer. Water Resources Assoc. pp. 403-414.

Bellrose, F.C. 1976. Ducks, Geese and Swans of North America. Stackpole Books, Harrisburg. Pennsylvania. $544 \mathrm{pp}$.

Bemot, C. 1979. Water Bank: Keeping Wetlands Wet. The Minnesota Volunteer 42(246):4.

Boto, K.G and W.H Patrick. Jr. 1979. Role of wetlands in the removal of suspended sediments In P.E. Greeson, et al. Wetland Functions and Values: The State of Our Understanding. Amer. Water Resources Assoc. pp. 479-489

Brown. D.E., C.H Lowe, and J.F. Hausler. 1977. Southwestern riparian communitses: their biotic importance and management in Arizona. In: R.R. Johnson and D.A. Jones (editors). Importance, Preservation and Management of Riparian Habitat. A Symposium. U.S.D.A. Forest Service. General Tech. Rept. RM-43. pp. 201 211

Carpenter, J.M and G.T Farmer. 1981. Peat Mınıng: An Initual Assessment of Wetland Impacts and Measures to Mittgate Adverse Effects. E.P.A. Report. Washington, D C. 6l pp.

Carter, V., M.S Bedinger, R.P. Novitski and W O Wilen. 1479 Water resources and wetlands. In: P.E. Greeson, et al. Wetland Functions and Values: The State of Our Understanding. Amer Water Resources Assoc. pp. 344-376.

Chabreck, R.H. 1979. Wildlife harvest in wetlands of the United States In: P.E. Greeson, et al. Wetland Functions and Values: The State of Our Understanding. Amer. Water Resources Assoc. pp. 618-631.

Clark, J.E. 1979. Fresh water wetlands: hahttats for aquatic invertebrates, amphibians, reptiles, and tish. In: P.E. Greeson, et al. Wetland Functions and Valıes: The State of Our Understanding. Amer Water Resources Assoc. pp. 330-343.

Crow, J.H. and K.B. MacDonald. 1979. Wetland values: secondary production. In: P.E. Greeson, et al. Wetland Functions and Values: The State of Our Lnderstanding. Amer. Water Resources Assoc. pp. 146-161.

de la Cruz, A.A. 1979. Production and transport of detritus in wetlands. In: P.E. Greeson, et al. Wetland Functions and Values: The State of Our Understanding. Amer. Water Resources Assoc. pp. 162-174.

Dean, R.G. 1979. Effects of vegetation on shoreline erosional processes. In: P.E. Greeson, et al. Wetland Functions and Values: The State of Our Understanding. Amer. Water Resources Assoc. pp 415-426.

DeLaune, R.D., W. H. Patrick, Jr. and R. J. Buresk. 1978. Sedimentation rates determined by $137 \mathrm{Cs}$ dating in a rapidly accreting salt marsh. Nature 275: 532-533.

Demms, E.F., Jr. and D. Pursley (editors). 1978. North American Furbearers: Their Management, Research and Harvest Status in 1976. International Assoc. Of Fish and Wildife Agencies. $157 \mathrm{pp}$.

Dwyer, T.J., G. Krapu and D. Janke. 1979. Use of prairie pothole habitat by breeding mallards. J. Wildl. Manage. $43(2)$ : 527-531.

Farnham, R.S. 1979. Wetlands as energy sources. In: P.E. Greeson, et al. Wetland Functions and Values: The State of Our Understanding. Amer. Water Resources Assoc. pp. 661-672.

Frederickson, L.H. 1979. Lowland hardwood wetlands: current status and habitat values for wildlife. In: P.E. Greeson, et al. Wetland Functions and Values: The State of Our Understanding. Amer. Water Resources Assoc. pp. 296-306.

Gates, J.M. and J.B. Hale. 1974. Seasonal Movement. Winter Habitat Use and Population Distribution of an East-Central Wisconsin Pheasant Population. Wisc. Dept. Nat. Resources. Tech. Bull. No. $76.56 \mathrm{pp}$.

Garbisch. E.W.. Jr. 1977. Marsh development for soil erosion. In: Proc. of the Workshop on the Role of Vegetation in Stabilization of the Great Lakes Shoreline. Great Lakes Basin Commission, Ann Arhor, Michigan. pp. 77-94.
Giulio, R.T.D. 1978. Wood Duck (AIx sponsa) Brood Usage of Agri cultural Fields and Wetlands in Concordia Pansh. Louisiana. M.S Thesss, Louisiana State Iniversity, Baton Rouge. $137 \mathrm{pp}$.

Good, R E., D.F. Whighan and R.L. Simpson. 1978. Freshwater Wetlands. Ecological Processes and Management Potential. Academic Press, New York. 378 pp.

Goodwin, R.H. and W.A. Niering. 1975. Inland Wetlands of the United States. Evaluated as Potential Registered Natural Landmarks. National Park Service. Nat. Hist. Theme Studies, No. 2. 550 pp.

Grant, R.R. Jr., and R. Patrick. 1970. Tinicum Marsh as a water purifier In: Two Studies of Tinicum Marsh. The Conservation Foundation. pp. 105-123

Greeson, P.B.. J.R. Clark and J.E. Clark (edıtors). 1979. Wetland Functions and Values: The State of Our Understanding. Proc. of the National Symposium on Wetlands. November 7-10. 1978. Amer Water Resources Assoc., Minneapolis, Minnesota. $674 \mathrm{pp}$.

Guthery, F.S. 1981. Playa basins and resident wildlife in the Texas Panhandle. In Playa Lakes Symposium Proceedings. December 4 5, 1979. Arlington, Texas. U.S. Fish and Wildufe Service. FWS/OBS-81/07. pp. 47-51

Hawkıns, P. and C.F. Leck. 1977. Breeding bird communities in a tudal freshuater marsh. Bull. N.J. Acad Sci. 22(1): 12-17

Hindall, S.M. 1975. Measurements and Prediction of Sediment Yields in Wisconsin Streams. U.S. Geological Survey Water-Resources Investigations 54-75. $27 \mathrm{pp}$.

Hoffman, G. R. 1977. Artificial establishment of vegetation and effects of fertilizer along shorelines of Lake Oahe and Sakakawea mainstem Missouri River reservors. In: Proc. Workshop on the Role of Vegetation in Stabilization of the Great Lakes Shoreline. Great Lakes Basin Commission, Anл Arbor, Michigan. pp. 95-109.

Jaworski, E. and C.N. Raphael 1978 Fish, Wildlıfe, and Recreational Values of Michigan's Coastal Wetlands. Michigan Dept. Nat. Resources report. $209 \mathrm{pp}$.

Johnsgard, P.A. 1956. Effects of water fluctuation and vegetation change on bird populations, particularly waterfowl. Ecology $37(4)$ : 689-701

Johnson, R.L. 1979. Timber hasvests from wetlands. In. P.E. Greeson, et al. Wetland Functions and Values: The State of Our Understanding. Amer. Water Resources Assoc. pp. 598-605.

Kadlec. J.A. and W.A. Wentz. 1974. State-of-the-art Survey and Evaluation of Marsh Plant Establishment Techniques: Induced and Natural. Vol. I: Report of Research. Tech. Rept. D-74-9. U.S. Army Engineers Waterways Expt. Stat., Vicksburg, Mississippi.

Klopatek, J.M. 1978. Nutrient dynamics of freshwater riverıne marshes and the role of emergent macrophytes. In: R.E. Good, D.F. Whigham, and R.L. Simpson (editors). Freshwater Wetlands. Ecological Processes and Management Potential. Academic Press, New York. pp. 195-216.

Kusler, J.A 1983. Our National Wetland Heritage. A Protection Guidebook. Environmental Law Institute, Washington, D.C. 167 pp.

Lee, C.R., R.E. Hoeppel, P.G Hunt and C.A Carlson. 1976. Feasibility of the Functional Use of Vegetation to Filter. Dewater, and Renıve Contaminants from Dredged Maternal. Tech. Rept. D-764. U.S. Army Engineers, Waterways Expt. Sta., Vicksburg, Mississippi.

Lee, G.F., E. Bentley, and R. Amundson. 1975. Effects of marshes on water quality. In: A.D. Hasler (editor). Coupling of Land and Water Systems. Springer-Verlag. New York. pp. 105-127.

Leitch, J.A. 1981. Wetland Hydrology: State-of-the-art and Annotated Bibloggraphy. Agric. Expt. Stat., North Dakota State Univ.. Fargo, No. Dak. Res. Rept. 82. $16 \mathrm{pp}$

Leopold, L.B. and M.G. Wolman. 1957. River Channel Patterns Braided, Meandering, and Straight. U.S. Geol. Survey Prof. Paper 282B.

Lewis, R., and J. Thomas. 1974. Proc. of the First Annual Conference on Restoration of Coastal Vegetation in Florida. Hillshorough Community College, Tampa. Florida.

Lieth, H. 1975. Primary productivity of the major vegetative units of the world. In: H. Lieth and R.H. Whittaker (editors). Productivity of the Biosphere. Springer-Verlag. New York. pp. 203-316. 
Ludden, A P., D.L. Frnnk, and D.H. Johnom 1983. Water sturage capacity of natural wetland depressuens in the Devils Lake Basin of North Dakota I Soil and Water Cons 38(1): $45-48$

MacDonald, P O. WV E. Fraver, and J K Clauser 1974 Documentation. Chronology, and Future Projections of Bottomland Hardwond Habitat Loss in the Lower Mrssissippl Alluvial Plan Vol 1: Basic Report U.S. Fish and Wildife Service, Ecological Services, Vicksburg, Mississippi. $133 \mathrm{pp}$.

Malcolm. J. 1478. Study of Wetland Dranage in Reldtun 10 Souris River Water Quantity and Quality as It Impacts I Clark Salyer Natwonal Wildlife Refuge. U.S. Fish and Wildite Serve Special Report.

Malcolm, J 1979. Relationship of Wetland Dramage to Flooding and Water Quality Probiems and the Impacts on J. Clark Salyer National Wildlife Refuge. U.S. Fish and Wildlife Service. Special Report.

McHugh. J.L. 1966. Management of Estuarine Fishes. Amer. Fish Soc., Spec. Pub. No. 3: 133-154

Merrell. T J. Jr. and K. V. Koski. 1979 Mabitat values of cuastal wetlands for Pactic Coast salmonids. In: P.E. Greeson. et al. Wetland Functions and Values: The State of Our Understanding. Amer. Water Resources Assoc. pp. 256-266

Motts. W.S. and R.W. Heeley. 1973 Wetlands and groundwater. In J.S. Larson (editor). A Guide to Important Chardeteristics and Val. ues of Freshwater Wetlands in the Northeast. University of Massachusetts, Water Resources Research Center. Pub. No. 31 pp. 5-8

Mundorff. M.J. 1950. Floodplain Deposits of North Carolina Piedmont and Mountain Streams as a Possible Source of Grounduater Supply. N.C. Div. Mineral Res. Bull. 59

Newton, R.B. 1981. New England Wetlands: A Primer. University of Massachusetts. Amherst. M.S Thesis. 84 pp

Novitski, R.P. 1978. Hydrology of the Nevin Wetland Near Madison. Wisconsin. U.S Geological Survey, Water-Resources Investigations 78-48. $25 \mathrm{pp}$.

Odum, E.P. 1961. The role of the tidal marshes in estuarne production. N.Y. State Conservationist 15: 12-15

Odum, H.T., K.C. Ewel, W.J. Mitsch, and J.W. Ordway. 1975. Recy cling Treated Sewage Through Cypress Wetlands in Florida University of Florida, Center for Wetlands, Gainsville. Occassional Pub. No. 1.

Patrick, W.H., Jr, G. Dissmyer, D.D. Hook, V.W. Lambou, H M Leitman, and C.H. Wharton. 1981. Characteristics of wetlands ecosystems of southeastern bottomland hardwood forests. In: J.R Clark and J. Benforado (editors). Report on a Bottomland Hard wood Wetlands Workshop. Lake Lanjer, Georgla. June 1-5, 1980 National Wetlands Technical Council. Washington. DC. pp. 6\$-89.

Peters. D.S., D.W. Ahrenholz, and T.R. Rice. 1979. Harvest and value of wetland associated fish and shellfish. In: Greeson, et al. Wetland Functions and Values: The State of Our Understanding. Amer. Water Resources Assoc. pp. 606-617.

Seibert, P. 1968. Importance of natural vegetation for the protection of the banks of streams, rivers, and canals. In: Nature and Environment Series ( $\mathrm{Vol}$. Freshwater). Council of Europe. pp. 35-67.

Sigafoos, R.S. 1964. Botanical Evidence of Floods and Floodplain Deposition, Vegetation, and Hydrologic Phenomena. U.S. Geol. Survey Prof. Paper 485-A.

Sloey, W.E., F.L. Spangler, and C.W. Fetter, Jr. 1978. Management of freshwater wetlands for nutrient assimilation. In: R.E. Good, et al. Freshwater Wetlands. Ecological Processes and Management Potential. Academic Press, New York. pp. 321-340.

Smith, A.G., J.H. Stoudt and J.B. Gollop. 1964. Prairie potholes and marshes. In. J.P. Linduska (editor). Waterfowl Tomorrow. U.S Fish and Wildlife Service, Washington, DC. pp. 39-50.

Stewart, R.E. and H.A. Kantrud. 1972. Vegetation of Prairie Potholes. North Dakota, in Relation to Quality of Water and Other Environmental Factors. U.S. Geol. Survey Prof. Paper 585-D. 36 pp

Stuber, P.J.R. 1983. User's Handbook for the Wetland Values Database. U.S. Fish and Wildlife Service. W/RMMG-83/W12. $47 \mathrm{pp}$.

Swift, B.L. 1980. Breeding Bird Habitats in Forested Wetlands of West-Central Massachusetts. M.S. Thesis, Univ of Massachusetts, Amherst. $90 \mathrm{pp}$.
Teal, J and M Teal. 1969. Lufe and Death of the Salt Natsh Audubon/Ballantme Books. Neu York. 274 pp

Tumer, R E 1477. Intertdal vegetatuon and commercial belds ot pen aeid shrimp. Trams. Aner. Fish. Soc 106. 411-416

U.S. Army Corps of Engineers 1970. Natural Valley Storage. A Part nership with Nature. Neu England Diviswon. Waltham. Massachusetts.

U.S. Department of the Interior. 1962. The value of wetlands to modern society. Proc. of Project MAR Cont., Nov. 12-16, 1962. Inter Union for the Conserv. of Nature. Publtcittion, Neu Series No 3 $57-63$

U.S Department of the Interior and Department of Comnerce. 1982 1980 Natıonal Survey of Fishing, Huntmg, and Wildlife-Associated Recreation. Fish and Wildhte Service and Bureau of Census. 150 pP.

U.S. Water Resources Council 1977. Estumated Flood Danages. Appendix B. Nationwide Analysis Report. Washington, D.C.

U.S. Water Resources Council. 1978. The Natun's Water Resources 1975-2000. Vol. 1: Summary. Washington. D.C. $86 \mathrm{pp}$

Verry. E.S. and D.H. Boelter. 1979. Peatland hydrology. In: P.E Greeson, et al. Wetland Functions and Values: The State of Our Understanding. Amer. Water Resources Assuc. pp. 389-402.

Wauer. R.H. 1977. Significance of R10 Grande nparian system upon the avıfauna In: R.R. Johnson and D. A. Jones (editors). Importance, Preservation and Management of Riparian Habıtat. A Symposium. U.S.D.A. Forest Service. General Tech. Rept. RM1-43. pp. $165-174$

Weller, M.W and C. E. Spatcher. 1965. Role of Habitat in the Distribution and Abundance of Marsh Birds. Jowa Agnc. Home Econ Exp. Sin. Spec. Rep. No. 43. 31 pp.

Wharton, C.H 1970. The Southern River Swamp - A Multiple Use Environment. School of Business Administration, Georgia State University. $48 \mathrm{pp}$

Wharton, C.H. 1978. The Natural Environments of Georgia. Georgia Dept. of Nat. Res., Atlanta. $227 \mathrm{pp}$.

Wharton, C.H. and W.M Kitchens. 1982. The Ecology of Bottomland Hardwood Swamps of the Southeast: A Community Profile. U.S Fish and Wildlife Service. Biological Services Program, Washıngton, DC. FWS/OBS - 81/37. 133 pP

Williams. J.D. and C.K. Dodd, Jr. 1979. Importance of wetlands to endangered and threatened species. In: P.E. Greeson, et al. Wetland Functions and Values: The State of Our Understanding. Amer. Water Resources Assoc. pp. 565-575

Windom. H.L. 1977. Ability of Salt Marshes to Remove Nutrients and Heavy Metals from Dredged Material Disposal Area Effluents Technical Rept. D-77-37. U.S. Army Engineers. Waterways Expt Sta., Vicksburg, Mississippi

Winter, T.C. and M.R. Carr. 1980. Hydrologic Setting of Wetlands in the Cottonwood Lake Area. Stutsman County. North Dakota. U.S Geological Survey. Water Resources Investigations 80-99. 42 pp.

Wolman, W.G. and L.B. Leopold. 1957. River Floodplains. Some Observations on Their Formation. U.S. Geol. Survey Prof. Paper 282-C.

Woodhouse, W.W.. E.D. Seneca, and S.W. Broome. 1976. Propagation and Use of Spartina alterniflora for Shoreline Erosion Abate ment. U.S. Army Coastal Engineering Research Center. Tech Rept. 76-2 


\section{CURRENT STATUS AND TRENDS OF U.S. WETLANDS}

\section{Current Status}

Wetlands exist in every state and their abundance varies due to climate, soils, geology, land use and other regional differences. Figure 25 shows the estimated extent of wetlands within each of the 50 states. Alaska, Louisiana, and Florida contain the most wetland acreage. Other states with considerable acreage include Alabama, Arkansas, Georgia. Maine. Michigan, Minnesota, Mississippi, North Carolina, South Carolina and Wisconsin. Smaller states like Delaware and New Jersey are also well represented by wetlands.

In the mid-1970's, an estimated 99 million acres of wetlands existed in the conterminous United States
(Frayer, et al. 1983). This amounts to an area equal to the size of California. Only 5\% of the land surface of the lower 48 states contains wetland. Alaska and Hawaii are not included in these figures. Estimates of Alaska's wetland resource vary, but 200 million acres probably exist.

The abundance of major wetland types in the conterminous U.S. is shown in Figure 26. Palustrine wetlands, including freshwater marshes and swamps, comprise $94 \%$ of the wetlands in the lower 48 states. In the mid$1970^{\circ} \mathrm{s}, 93.7$ million acres of palustrine wetlands were present, with over half of this acreage being forested wetland and about a third being emergent wetland. Remaining palustrine wetland acreage equals an area about the size of California. By contrast, only 5.2 million acres of estuarine wetlands existed by the mid-1970 $\mathrm{s}$. This amounts to an area approximately the size of Massachusetts and represents only $0.3 \%$ of the land surface of the lower 48 states.

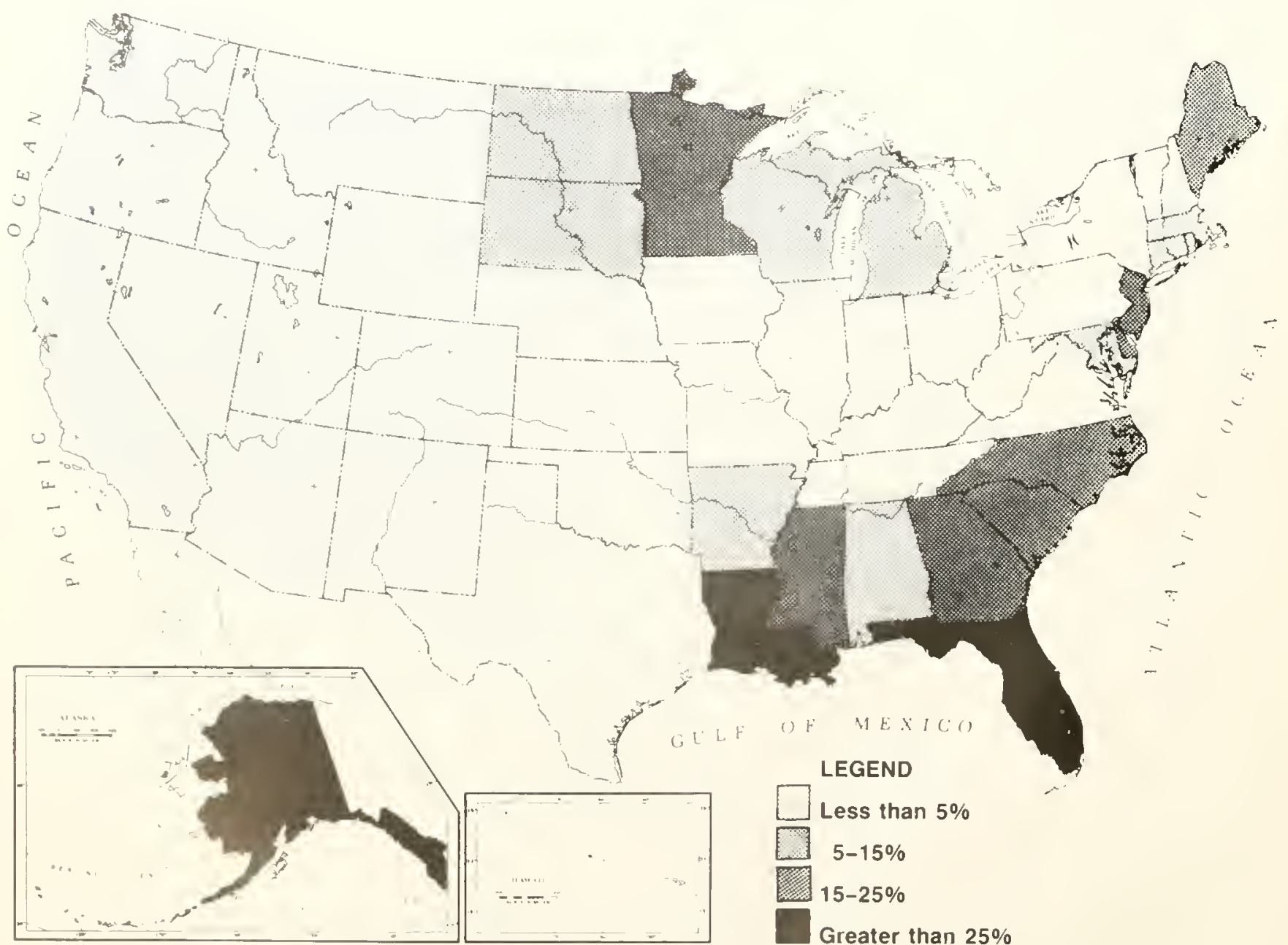

Fig. 25. Relative abundance of wetlands in the U.S. (1984). Percent of each state represented by wetland is shown. 
ESTUARINE INTERTIDAL FLATS

ESTUARINE EMERGENT WETLANDS

ESTUARINE FORESTED AND

SCRUB-SHRUB WETLANDS

PALUSTRINE EMERGENT WETLANDS

PALUSTRINE SCRUB-

SHRUB WETLANDS

PALUSTRINE FORESTED WETLANDS

\section{OTHER PALUSTRINE WETLANDS}

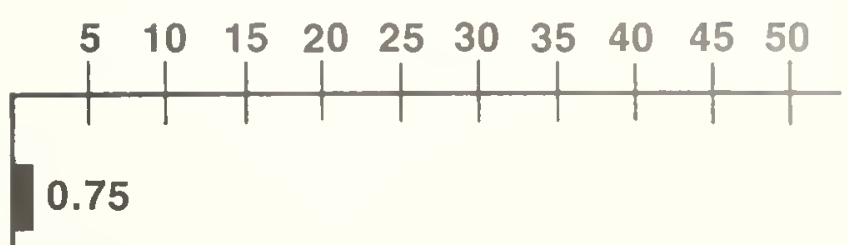

\section{9}

0.57
28.4

10.6

Fig. 26. Extenl of wetlands in the conterminous U.S, in the mid-1970's (from Frayer, et al, 1983).

Estimates of the original wetland acreage present at this country's settlement vary, since the available information is scattered and largely incomplete. However, a very reliable account places this acreage at 215 million acres for the conterminous United States (Roe and Ayres 1954). Thus, today's wetland resource in the lower 48 states probably represents less than $46 \%$ of our original wetlands (Figure 27).

\section{MILLION ORIGINAL ACRES}

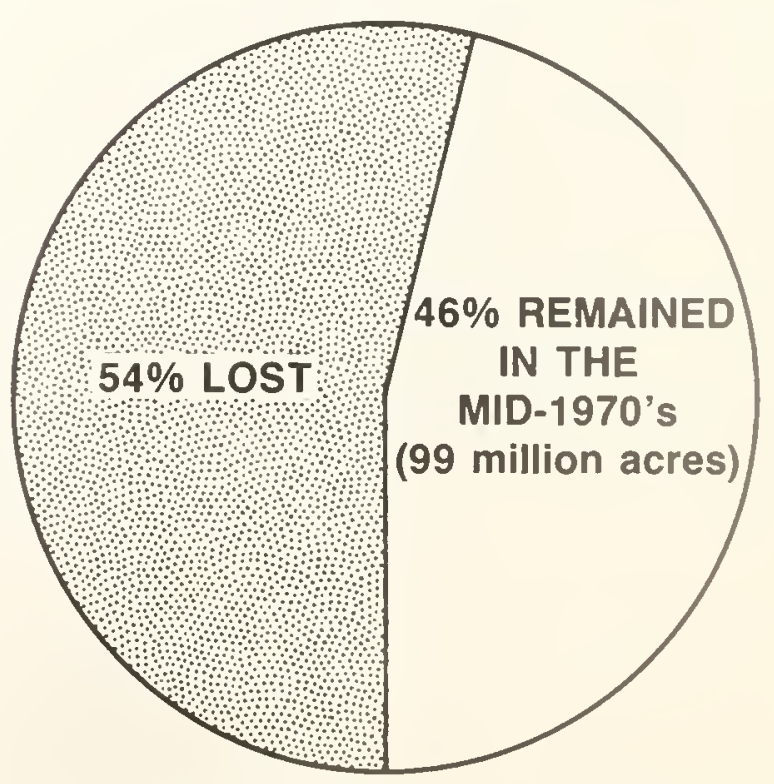

Fig. 27. Original and remaining acreages of wetlands in the conterminous U.S. (from Roe and Ayres 1954; Frayer, el al. 1983). 


\section{Forces Changing Wetlands}

Wetlands represent a dynamic natural environment which are subjected to both human and natural forces. These forces directly result in wetland gains and losses as well as affect their quality. Tahle 2 outlines major causes of wetland loss and degradation.

Table 2. Major canse's of wetand loss and degradation (Zimn and Copelund 1982; Gosselink and Baumanm 1980).

\section{Human Threats}

Direct:

1. Drainage for crop production, timber production and mosquito control.

2. Dredging and stream channelization for navigation channels, flood protection, coastal housing developments, and reservoir maintenance.

3. Filling for dredged spoil and other solid waste disposal. roads and highways, and commercial, residential and industrial development.

4. Construction of dikes, dams, levees and seawalls for flood control, water supply, irrigation and storm protection.

5. Discharges of materials (e.g., pesticides, herbicides, other pollutants, nutrient loading from domestic sewage and agricultural runoff, and sediments from dredging and filling, agricultural and other land development) into waters and wetlands

6. Mining of wetland soils for peat. coal, sand, gravel, phosphate and other materials.

Indirect:

1. Sediment diversion by dams, deep channels and other structures.

2. Hydrologic alterations by canals, spoil banks. roads and other structures.

3. Subsidence due to extraction of groundwater, oil, gas, sulphur, and other minerals.

Natural Threats:

1. Subsidence (including natural rise of sea level)

2. Droughts

3. Hurricanes and other storms

4. Erosion

5. Biotic effects, e.g., muskrat, nutria and goose "eat-outs."

Natural events influencing wetlands include rising sea level, natural succession, the hydrologic cycle, sedimentation, erosion, beaver dam construction and fire. The rise in sea level, for example, both increases and decreases wetland acreage depending on local factors. Along the eastern shore of Chesapeake Bay, it is allowing coastal wetlands to establish in former upland pine areas, while permanently flooding wetlands at lowest elevations. Rising sea level is one factor converting salt marshes to bay bottoms in Louisiana. Natural succession and fire typically change the vegetation of a wetland usually with no net loss or gain. However, fire in Alaska's permafrost wetlands may convert the area to nonwetland. Disturbance of the vegetative cover can cause the frostline to recede, and dry site plants may become established. The hydrologic cycle refers to the natural cycle of wet and dry periods over time. Great Lakes water levels, for example. Aluctuate drastically on a roughly 20 year cycle. This adds an important dimension to wetlands, making them vulnerable to drainage during dry periods. Similar conditions have resulted in wetland drainage in the Prairie Pothole Region. The activities of beavers create or alter wetlands by damming stream channels. Thus, natural forces act in a variety of ways to create, destroy and modify wetlands.

Human actions are particularly significant in determining the fate of wetlands. Unfortunately, many human activities are destructive to wetlands, either converting them to agricultural or other lands or degrading their quality. Key human impacts include drainage for agriculture; channelization for flood control; filling for housing. highway, industry and sanitary landfills; dredging for navigation channels, harbors and marinas; reservoir construction; timber harvest; peat mining; oil and gas extraction; strip mining: groundwater extraction: and various forms of water pollution and waste disposal. A few actions do, however, create wetlands. Construction of farm ponds and, in some cases, reservoirs and irrigation projects may increase wetland acreage, although valuable natural wetlands may be destroyed in the process. Marsh creation and restoration of previously altered wetlands can also be beneficial. Federal and state fish and wildlife agencies traditionally manage wetlands to improve their value to waterfowl. Wetland protection efforts serve to help maintain and enhance our Nation's wetland resources. despite mounting pressures to convert them to other uses.

\section{Recent National Wetland Trends}

Information on historical wetland gains and losses is limited and often subjective. The Service recently completed a scientifically sound study of the current status and recent trends of U. S. wetlands between the mid1950 's and mid-1970's (Frayer, et al. 1983). Although the results of this study are valid at the national level, few comparable statistics exist for individual states. The following discussions will summarize the results of the Service's national study and other regional studies. Specific problem areas where wetlands are in greatest jeopardy will be highlighted. 


\section{Recent Guins}

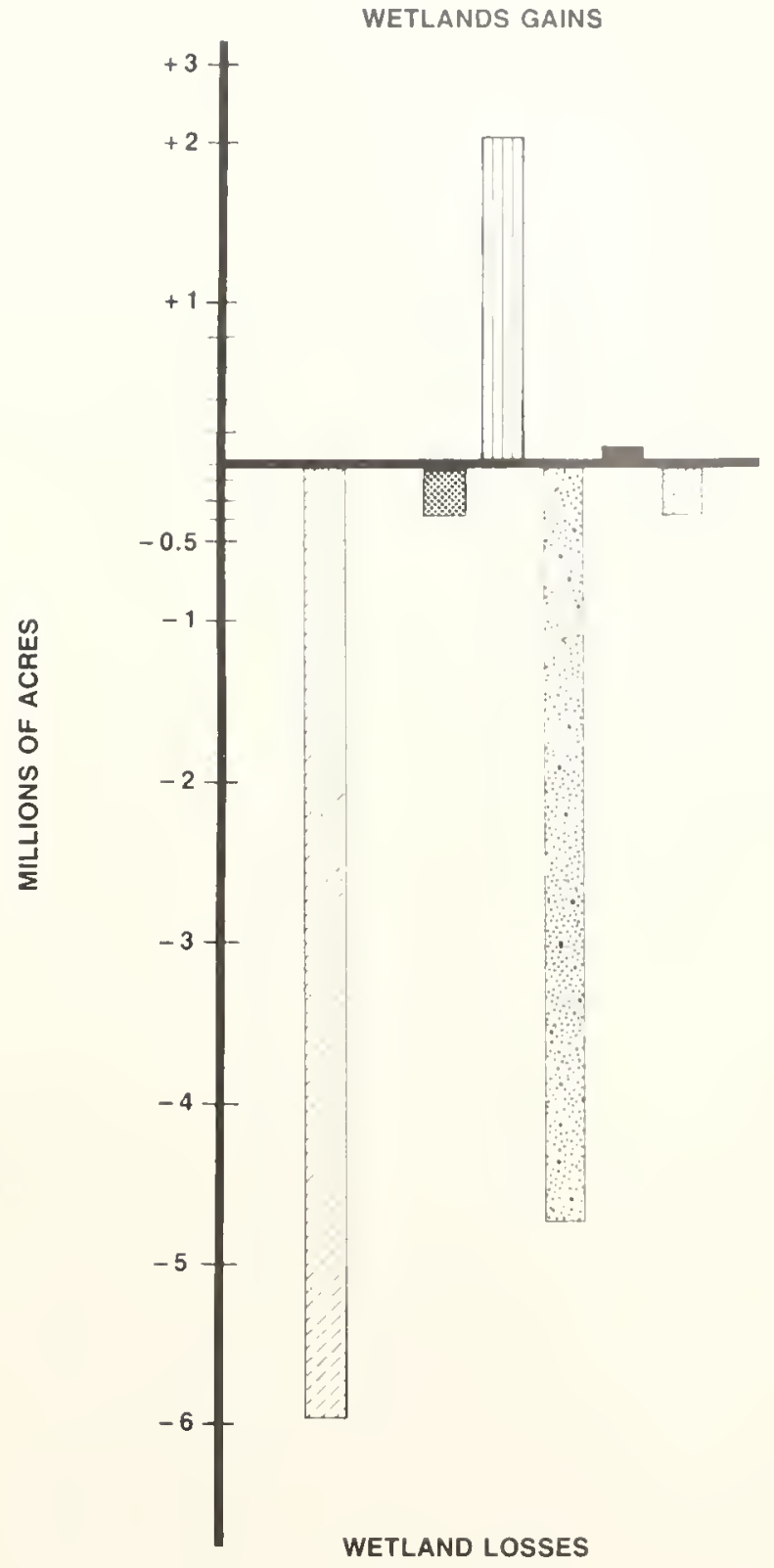

LEGEND

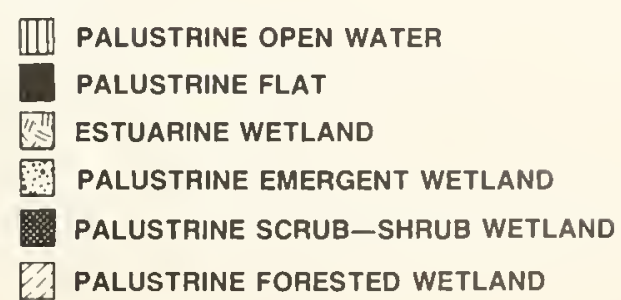

Fig. 28. Net losses and gains in wetlands of the conterminous U.S. between the mid-50's and mid-70's (from Frayer, et al. 1983).
Slight net gains in deepwater habitats - nannate lakes and reservoirs and coastal waters - and in two wetland types - inland flats and ponds - took place between the mid-50's and mid-70's (Figure 28). Like acreage increased by 1.4 million acres with $94 \%$ of this gain occurring in the eastern half of the country. These new lakes and reservoirs were mostly created from uplands, although vegetated wetlands were also destroyed. Some new wetlands, however, have formed along the edges of these new waterbodies.

During the same period, coastal open waters increased by 200,000 acres. Most of this gain came from Louisiana at the expense of coastal wetlands which are being permanently flooded at an accelerating rate. Causes of this change from marsh to open water are numerous and complicated and include natural rise of sea level, subsidence of the coastal plain, levee construction, channelization, and oil and gas extraction.

Two wetland types experienced gains between the mid50 s and mid-70's: inland llats and ponds. Two hundred thousand acres of unvegetated wetland flats and 2.1 million acres of ponds were created. Pond acreage nearly doubled from 2.3 million acres to 4.4 million acres, primarily due to farm pond construction in the Central and Mississippi Flyways. Most of this pond acreage came from former upland, although 145,500 acres of forested wetlands and 385.000 acres of emergent wetlands were changed to open water.

\section{Recent Losses}

Despite these modest gains, wetland losses were enormous. In the mid-1950's, there were an estimated 108 . I million acres of wetlands in the lower 48 states (Frayer, et al. 1983). Just 20 years later, these wetlands were reduced to 99 million acres, despite some gains in wetlands due to reservoir and pond construction, beaver activity. and irrigation and marsh creation projects. This loss of 9 million acres equates to an area about three times the size of Connecticut or twice the size of New Jersey. Actually, 11 million acres of our most valuable natural wetlands were destroyed, but these acreage losses were minimized by gains of 2 million acres of newly created wetlands. giving a net loss of 9 million acres. The average rate of wetland loss from the mid-50's to the mid-70's was 458.000 acres per year: 440.000 acres of palustrine losses and 18,000 acres of estuarine wetland losses. This annual loss equals an area about half the size of Rhode lsland.

Agricultural development involving drainage was responsible for $87 \%$ of recent national wetland losses. while urban development and other development caused only $8 \%$ and $5 \%$ of the losses, respectively (Figure 29). Agriculture had the greatest impact on forested wetlands 

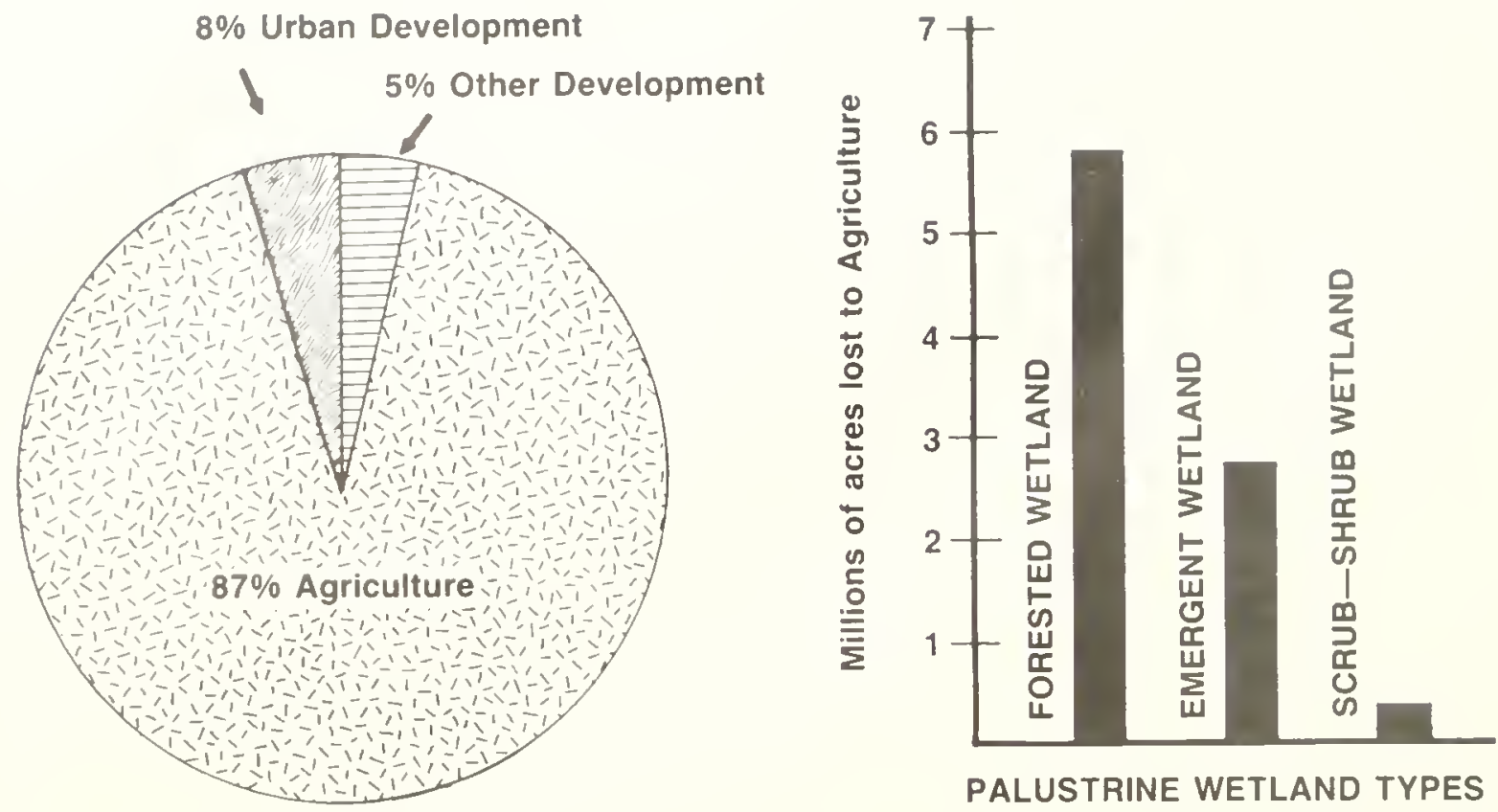

Fig. 29. Causes of recent wetland losses (mid-1950's 10 mid-1970's) in the conterminous U.S.; losses to agriculture are highlighted (from Frayer, et al. 1983).

and emergent wetlands, with losses of 5.8 and 2.7 million acres, respectively. In addition, 0.4 million acres of scrub-shrub wetlands were converted to agricultural use between the mid-50's and the mid-70's.

The most extensive wetland losses occurred in Louisiana, Mississippi. Arkansas. North Carolina. North Dakota, South Dakota, Nebraska, Florida and Texas. Greatest losses of forested wetlands took place in the Lower Mississippi Valley with the conversion of bottomland hardwood forests to farmland. Shrub wetlands were hardest hit in North Carolina where pocosin wetlands are being converted to cropland or pine plantations or mined for peat. Inland marsh drainage for agriculture was most significant in the Prairie Pothole Region of the Dakotas and Minnnesota, Nebraska's Sandhills and Rainwater Basin and Florida's Everglades. Between the mid-50's and mid-70's, estuarine wetland losses were heaviest in the Gulf states, i.e., Louisiana, Florida and Texas. Most of Louisiana's coastal marsh losses were attributed to submergence by coastal waters. In other areas, urban development was the major direct man-induced cause of coastal wetland loss. Dredge and fill residential development in coastal areas was most significant in Florida, Texas, New Jersey, New York and California.

\section{Regional Historical Perspective}

While the national decline in wetlands is dramatic. losses in particular regions and states are even more startling. For example. California has lost over $90 \%$ of its original wetland resource (U.S. Fish and Wildlife Service 1977). Less than $5 \%$ of lowa's natural wetlands exist and over $90 \%$ of the wetlands in Nebraska's Rainwater Basin have been destroyed (Bishop 1981; Farrar 1982). Only $20 \%$ of the original bottomland hardwood forests in the Lower Mississippi Alluvial Plain remain (McDonald. et al. 1979). Other states with less than half of their original wetlands or certain types include Michigan. Minnesota, Louisiana. North Dakota, and Connecticut (Table 3). By 1955. Michigan had lost 8 million acres of wetlands (Michigan Department of Natural Resources 1982). Ohio, Indiana and Illinois probably have lost over half of their wetlands, but supportive statewide data are not available. In selected areas of Illinois, wetland losses have been dramatic. For example, virtually all wetlands have been eliminated in the East-Central Region, Big Prairie Region and Green River Watershed. while $98 \%$ of Illinois' southern bottomland swamps have been destroyed (lllinois Department of Conservation 1983). 


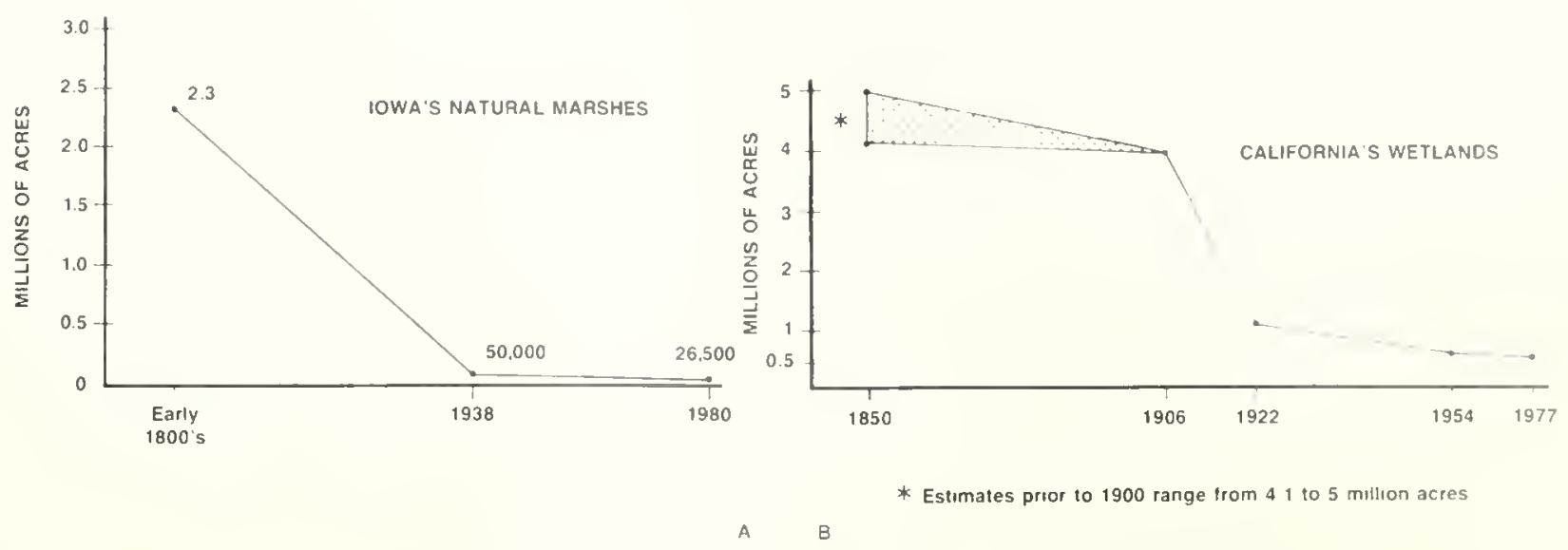

Fig. 30. Historical losses of wellands in towa (a) and California (b) (from Bishop 198t and U.S. Fish and Wildlife Service 1977).

In many areas, wetland destruction was greatest from the mid-1800's to the early 1900 's due to passage of the Swamp Land Acts of 1849, 1850, and 1860. These acts granted all swamp and overflow lands to 15 states: Alabama, Arkansas, California, Florida, lllinois, Indiana, lowa, Louisiana, Michigan, Minnesota, Mississippi, Missouri, Ohio, Oregon and Wisconsin (Shaw and Fredine 1956). These states were to drain these wetlands for agriculture by constructing levees and drainage ditches. About 65 million acres had been transferred from the Federal government to the states by 1954. Historical losses of Jowa's and California's wetlands illustrate accelerated wetland destruction in the late 1800 's and early 1900’s (Figure 30).

The original 13 states had retained all lands within their borders when the Federal government was established and Texas also kept all its land at the time of annexation. Interestingly, the extensive coastal wetlands of these 14 states were never owned by the Federal government and. by contrast. coastal wetland losses have been more recent. Between 1954 and 1978, the loss rate of coastal wetland doubled due primarily to post-war urban and industrial development in the U.S. coastal zone and to accelerated erosion and subsidence of Louisiana's vast coastal marshes (Gosselink and Baumann 1980).

While wetland losses in some states or regions may have been heaviest at the turn of the century, loss rates remain high in many areas. Between 1955 and 1978. Kansas lost $40 \%$ of its wetlands (Elliott. U.S.F.W.S. pers. comm.). In 11 linois, an estimated $20 \%$ of its wetlands are destroyed every decade (Great Lakes River Basin Commission 1981). About 6.7 million acres of Ohio"s original wetlands have been drained, while over half of its wetlands along Lake Erie have been destroyed since 1954 (Weeks 1974). Kentucky's wetlands along the Mississippi and Ohio Rivers have been reduced by $37 \%$ in the past twenty years (Kentucky Department of Fish and Wildlife Resources 1983). Heavy annual losses are continuing in the bottomland hardwood forested wetlands of the Lower Mississippi Delta and accelerating in pocosin wetlands along the North Carolina coast (MacDonald. et al. 1979; Richardson, et al. 1981). Some examples of recent wetland loss rates are shown in Table 4.

Recent trends in Delaware, Maryland, and New Jersey illustrate the effect of state wetland protection. Before passage of the Wetlands Act in 1973, Delaware was losing almost 450 acres of estuarine wetland each year. After the law, losses dropped to just 20 acres annually (Ilardisky and Klemas 1983). Coastal wetland losses in Maryland and New Jersey were also drastically reduced through wetland regulations. In addition to state laws, the Clean Water Act added a level of Federal protection to these wetlands nationwide in the early 1970's. Effective implementation of similar laws in other states has probably reduced wetland losses substantially.

\section{Current Regional Development Pressures}

In the Northeast, coastal wetlands are now well protected by state laws. Inland wetlands, however, continue to be vulnerable to development pressures in many areas. 
although they are protected to varying degrees by the Federal government through the Clean Water Act and by a few states with wetland protection laws. Urbanization seriously threatens inland wetlands in northern New Jersey and near other growing urban centers. Peat mining and resort development are major causes of wetland losses in the Pocono Region of Pennsylvania. Agricultural impacts are greatest in the bottomland hardwood swamps of Delaware. Maryland and Virginia and in New York's mucklands.

Agricultural drainage of wetlands is continuing to destroy large tracts of wetlands in the Southeast, especially in the Lower Mississippi Delta. Florida, and along the coastal plain of North Carolina. Bottomland hardwoods are heing clearcut for timber. and then cleared and drained for crop production, chiefly soybeans. Pocosin wetlands are similarly used as well as being mined for peat. Many inland wetlands are being converted to pine

Table 3. Examples of wetland losses in various states. plantations throughout the Southeast. Phosphate mining in Florida and North Carolina is destroying considerable wetland acreage. Puerto Rico's inland marshes ("savannahs") are being transformed into sugar cane farms. Coastal wetland destruction has slowed in most states with passage of protection laws, but enforcement may present problems.

Agricultural development in the Midwest corn belt and Great Plains remains the greatest threat, by far, to the remaining inland wetlands. Coastal marshes along the Great Lakes are continuing to be impacted by industrial. residential, and agricultural development. Although several of the Midwestern states have laws protecting certain wetlands or regulating certain activities in wetlands, agricultural drainage is still largely unregulated.

In the western states, agricultural development remains the primary threat to wetlands. Drainage and irrigation impacts, such as the Garrison Diversion, continue at high

\begin{tabular}{|c|c|c|c|c|}
\hline State or Region & $\begin{array}{c}\text { Original } \\
\text { Wetlands } \\
\text { (acres) }\end{array}$ & $\begin{array}{l}\text { Today's } \\
\text { Wetlands } \\
\text { (acres) }\end{array}$ & $\begin{array}{c}\text { \%e of } \\
\text { Wetlands } \\
\text { Lost }\end{array}$ & Source \\
\hline lowa's Natural Marshes & 2.333 .000 & 26.470 & 99 & Bishop (1981, pers. comm.) \\
\hline California & $5,000,000$ & 450,000 & 91 & $\begin{array}{l}\text { U.S. Fish and Wildlife } \\
\text { Service (1977) }\end{array}$ \\
\hline Nebraska's Rainwater Basin & 94.000 & 8.460 & 91 & Farrar (1982) \\
\hline Mississippi Alluvial Plain & 24.000 .000 & $5,200,000$ & 78 & MacDonald, et al. (1979) \\
\hline Michigan & $11,200.000$ & $3,200,000$ & 71 & $\begin{array}{l}\text { Michigan Department of } \\
\text { Nat. Res. (1982) }\end{array}$ \\
\hline North Dakota & $5,000,000$ & $2,000,000$ & 60 & $\begin{array}{l}\text { Elliott, U.S. FWS, } \\
\text { (pers.comm.) }\end{array}$ \\
\hline Minnesota & $18,400,000$ & $8,700,000$ & 53 & Univ. of Minn.(1981) \\
\hline Louisiana’s Forested Wetlands & $11,300,000$ & 5.635 .000 & 50 & Turner and Craig (1980) \\
\hline Connecticut's Coastal Marshes & 30.000 & 15.000 & 50 & Niering (1982) \\
\hline North Carolina's Pocosins & 2.500 .000 & $1.503 .000^{*}$ & 40 & Richardson. et al. (1981) \\
\hline South Dakota & $2,000,000$ & $1,300,000$ & 35 & $\begin{array}{l}\text { Elliott, U.S. FWS. } \\
\text { (pers.comm.) }\end{array}$ \\
\hline Wisconsin & 10.000 .000 & 6.750 .000 & 32 & $\begin{array}{l}\text { Wisconsin Dept. of Nat. Res. } \\
\text { (1976) }\end{array}$ \\
\hline
\end{tabular}

*Only 695,000 acres of pocustns reman undisturbed; the rest are partially drained, developed or planned for development. 
Table 4. Examples of recent wetland loss rates.

State or Region

Lower Mississippi Alluvial Plain

Louisiana`s Forested Wetlands

North Carolina’s Pocosins

Prairie Pothole Region

Louisiana’s Coastal Marshes

Great Lakes Basin

Wisconsin

Michigan

Kentucky

New Jersey's Coastal Marshes

Palm Beach County, Florida

Maryland's Coastal Wetlands

New York's Estuarine Marshes

Delaware's Coastal Marshes

* Loss rate after passage of state coastal wetland prolection laws.

rates. With increased tension over water rights, remaining wetlands may be deprived of sufficient quantities of water to function properly. This is especially true in Colorado where high population growth has increased demand for water. Urban and industrial development is destroying wetlands along the Great Salt Lake and near other urban centers.

Along the West Coast, coastal wetlands are generally protected by state laws, yet they are still under heavy pressure for urban and industrial development. Inland wetlands remain subject to agricultural pressures, particularly in California's Central Valley and the Great Basin of Nevada, Oregon, and Idaho. Degradation of existing wetlands through urban and agricultural runoff remains a problem.

Alaska's wetlands were once subject to very few development pressures. With the discovery of significant de-

\author{
Loss Rate \\ (acres/vear) Source
}

$\begin{array}{cl}165,000 & \text { MacDonald, et al. (1979) } \\ 87,200 & \text { Turner and Craig (1980) } \\ 43,500 & \text { Richardson, et al. (1981) } \\ 33,000 & \text { Haddock and DeBates (1969) } \\ 25,000 & \text { Fruge (1982) } \\ 20,000 & \begin{array}{c}\text { Great Lakes River Basin Comm. } \\ \text { (1981) }\end{array}\end{array}$

20.000 Wisconsin Department of Natural Resources (1976)

6,500 Weller (1981)

3.600 Kentucky Department of Fish \& Wildlife Resources (1983)

3,084 Ferrigno, et al. (1973)

$50 *$ JACA Corporation (1982)

3,055 U.S. Fish and Wildlife Service (1982)

1.000 Redelfs (1983)

740 O'Connor and Terry (1972)

444 Hardisky and Klemas (1983)

$20 *$

posits of oil and gas and the subsequent pipeline construction and energy development, many wetlands have recently been altered. The oil boom has also in creased human population densities, resulting in increased pressure on wetlands for urban development. Increases in timber harvest, mining, and agricultural activities are also threatening large areas of wetland in Alaska.

\section{National Problem Areas}

While wetland losses and degradation continue throughout the country, there are several areas where wetlands are in greatest jeopardy from a national standpoint. These areas and their threatened wetland types include: (1) estuarine wetlands of the U.S. coastal zone, (2) Louisiana's coastal marshes, (3) Chesapeake Bay"s 
submerged aquatic beds. (4) South Florida's palustrine wetlands, (5) Prairie Pothole Region's emergent wetlands, (6) wetlands of Nebraska's Sandhills and Rainwater Basin, (7) forested wetlands of the Lower Mississippi Alluvial Plain. (8) North Carolina's pocosins, and (9) western riparian wetlands. Most of these regions are under intense pressure from agricultural interests, while the effect of urbanization and industrial development is more localized. Northern New Jersey is used to illustrate these non-agricultural impacts. The following subsections summarize the nature of these national problems.

\section{Estuarine Wetlands of the U.S. Coastal Zone'}

Estuarine marshes and mangrove swamps are highly regarded for their commercial and recreational fisheries value. Protecting these wetlands has, however, only recently received national attention. In the past. coastal

\section{COASTAL WETLAND LOSS IN U.S.}

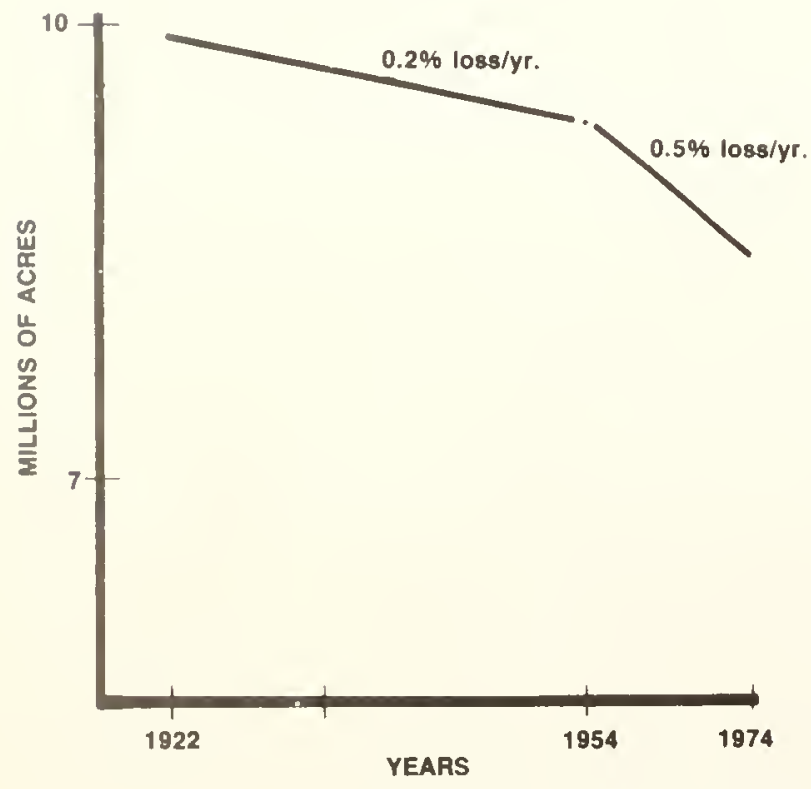

Fig.31. Rate of coastal wetland loss in the conterminous U.S. (from Gosselink and Baumann 1980). Eslimates include both estuarine and tidal freshwater wetland losses.

wetlands were viewed chiefly as potential sites for development. Between the 1950's and the mid-1970's. wetland losses were heaviest (Figure 31). The National Marine Fisheries Service (1983) estimated annual fishery losses at $\$ 208$ million due to estuarine marsh losses from 1954 to 1978. Accelerating wetland destruction aroused much public concern which led to the passage of tidal wetland protection laws in many coastal states and to stricter enforcement of existing Federal laws in the $1960^{\circ} \mathrm{s}$ and the 1970's. Unfortunately, over half of the coastal wetlands in the lower 48 states have been destroyed. Nonetheless. estuarine wetlands are still sought after by developers for residential and resort housing. marinas, and other uses.

Estuarine wetland losses have been greatest in 5 states: California, Florida, Louisiana, New Jersey and Texas. Louisiana is losing them at a rate of 25.000 acres per year due to coastal subsidence and other causes (Fruge 1982: see the following subsection for discussion). Outside of Louisiana, coastal wetland losses are directly related to population density (Gosselink and Baumann 1980). Urbanization (i.e., residential home construction) has been responsible for over $90 \%$ of the losses directly attributed to human activites (Figure 32; Frayer, et al. 1983). Accelerated urban development and increased groundwater withdrawals have resulted in salt water contamination of public water supplies in many coastal communities.

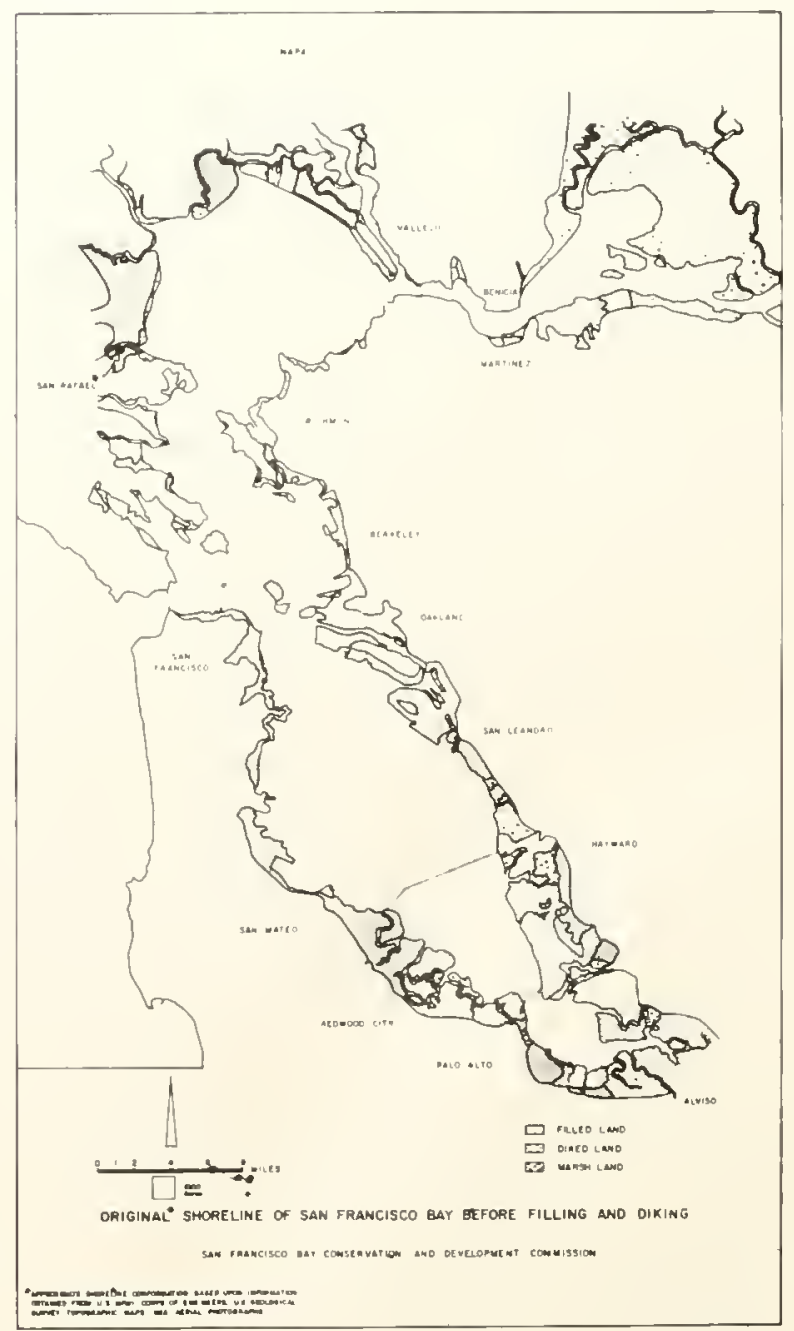

Fig.33. The status of wetland filling and diking in San Francisco Bay prior to the mid-1960"s (from Hedgpeth 1978). 


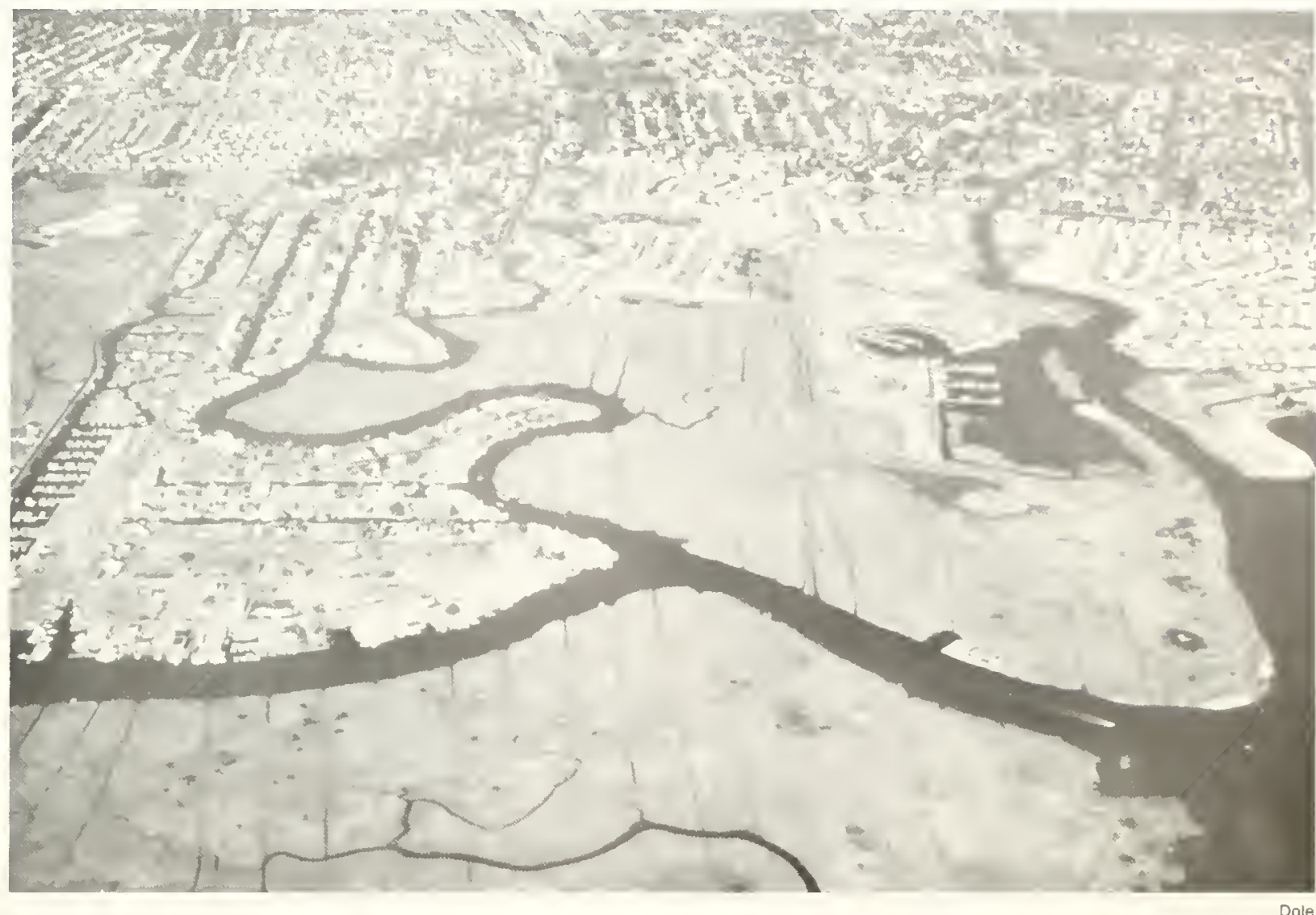

Fig. 32. Filling of estuarine wetlands for residential housing in Long tsland, New York and other coastal areas was particularly heavy in the 1950 's and $1960^{\circ} \mathrm{s}$. Wetland laws in most coastal states now protect these valuable wetlands.

While most of the coastal wetlands exist along the Alaskan, Atlantic and Gulf coasts. San Francisco Bay represents an interesting example of tidal wetland alteration. San Francisco Bay is an important wintering area for waterfowl, especially whistling swans, pintails, shovelers, canvasbacks, scaup, and ruddy ducks. About 25\% of the continent's population of whistling swans winter here as does roughly $40 \%$ of North America's ruddy ducks (Bellrose 1976). Originally, more than 200,000 acres of coastal marshes existed in the Bay region. Today, less than $20 \%$ remain (U.S. Fish and Wildlife Service and California Department of Fish and Game 1979). Most of the original wetlands were filled for urban and industrial development, while many remaining tidal marshlands were diked to create salt-evaporating ponds (Figure 33). Since 1976, coastal wetlands have been protected through the Califormia State Coastal Act. while the San Francisco Bay Conservation and Development Commission has been active in wetlands preservation since 1969. Efforts are now needed to restore degraded or modified wetlands to a more natural condition, so that they can once again serve as valuable fish and wildlife habitats.

All coastal states in the lower 48 . except Texas, have enacted special laws to protect estuarine wetlands. These laws vary considerably in their degree of protection, since a few exempt major activities that alter wetlands or apply only to state-owned lands. Section 10 of the River and Harbor Act of 1899 and Section 404 of the Clean Water Act of 1977 mandate a strong Federal role for protecting the Nation's coastal wetlands. Federal permits are required for most types of construction in estuarine wetlands. While the regulatory tools to protect coastal wetlands are in place, continued enforcement of existing laws is required to maintain the integrity of the remaining wetlands. In addition to regulation, the Coastal Barrier Resources Act of 1982 removes Federal subsidies and discourages development of approximately 700 miles of designated coastal barriers and adjacent wetlands. Its greatest impacts in reducing coastal wetland loss should occur in Alabama, Florida, North and South Carolina and Texas.

\section{Louisiana's Coastal Marshes}

Louisiana possesses roughly one-third of the coastal marshes in the conterminous U.S. (Turner and Gosselink 1975). The state's multi-million dollar commercial inshore shrimp fishery is directly proportional to the area of intertidal emergent wetland (Turner 1979). Along most 
coasts, salt marshes appear to be maintaning themselves through marsh building or accretion despite a worldwide rise in sea level. In Louisiana, however, this is not true as large expanses of coastal marshes are being permanently flooded by rising sea level (Figure 34). Vertical marsh accretion has not kept pace with coastit submergence over the past 30 years. The marsh is accreting at a rate of 0.33 inches yearly. while submergence is occurring at 0.5 inches per year (DeLanne, et al. 1983). The rate of subsidence here is more than five times as high as the average rate of glohal sea level rise over the past century (Boesch, et al. 1983). Currently, an estimated 40 square miles or 25,000 acres of coastal marshes are lost each year (Fruge 1982). Besides direct losses, salt water intrusion is killing freshwater vegetation in tidal freshwater marshes and converting these types to more brackish wetlands or open water. It also has accelerated the advance of the predaceous oyster drill into productive oyster beds.

The causes of Louisiana coastal marsh loss are numerous and complicated (Craig, et al. 1980). A combination of factors both natural and man-induced are responsible. Coastal subsidence, rise in sea level and the cyclical processes of Mississippi River Delta growth and deterioration represent the major natural forces. The Mississippi River is trying to shift its course into the Atchafalaya River, but the U.S. Army Corps of Engineers is only allowing $30 \%$ of the Mississippi and Red River flows to

MISSISSIPPI RIVER ACIIVE DELTA (1956)

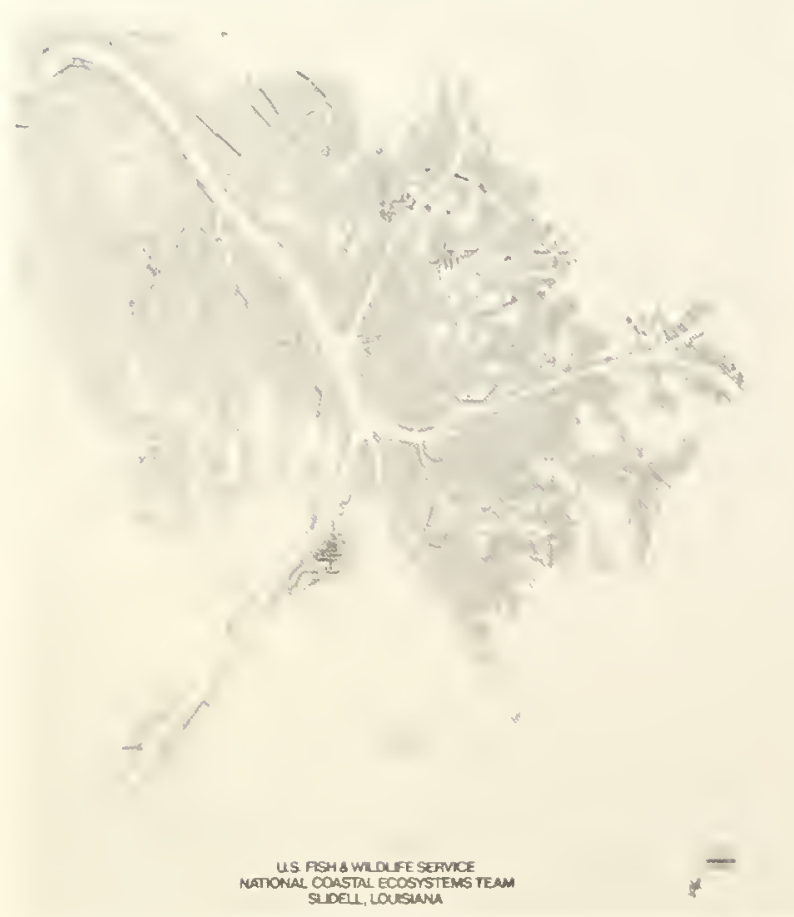

be moved down the Atchafalaya. This is still enough to get some marsh building in Atchafalaya Bay. An estimated 120,000 acres of marsh will be created here in the next 30 to 50 years. but this will not off'set heavy marsh losses in other areas of Louisiana (Louisiana State University 1983). Man's impacts include channelization and levee construction along the Mississippi River. canal dredging for navigation and energy operations, and subsidence from extraction of groundwater, minerals, oil and gas. Channelization and canal construction have increased marsh erosion and salt water intrusion along the coast. Man-made levees have disrupted the natural marsh building process by preventing overflow of sediment rich waters.

Efforts must be made to reduce man's adverse impacts on Louisiana's coastal marshes. Specific wetland preservation and restoration actions should be taken immediately. These actions include diverting Mississippi and Atchafalaya River flows into areas experiencing salt water intrusion and accelerated wetland loss, creation of new marsh through careful placement of dredged material, improved water management in existing marsh areas, and reducing petroleum industry canal dredging through increased use of directional drilling. Future research studies should improve our understanding of the importance of causal factors and address mechanisms to improve the future for this rapidly diminishing resource.

Courtesy of USFWS National Coastal Ecosystem Team

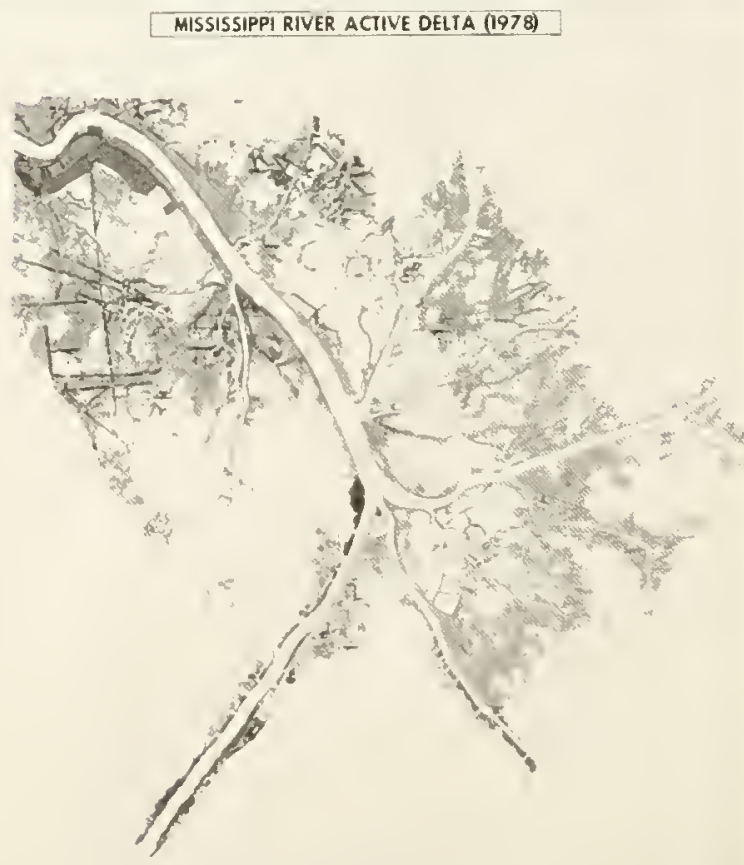

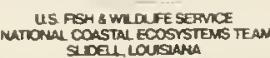

Fig. 34. Louisiana's coastal marshes are being permanently flooded by Gulf of Mexico waters at an accelerating rate. Example shows marsh changes between (a) 1956 and (b) 1978 . 


\section{Chesapeake Bay's Submerged Aquatic Beds}

Situated in eastern Maryland and Virginia, Chesapeake Bay is the largest estuary in the United States. Many rivers drain into the Bay including the Susquehanna, Potomac, Patuxent, James, York and Chester (Figure 35).

The Bay once represented the primary overwintering area for canvasback ducks which fed on submerged aquatic vegetation (Figure 36). Fifty percent of the Atlantic Flyway population of canvasbacks were found in the Bay region (Stevenson and Confer 1978). While still among the more important overwintering areas for canvasbacks, Chesapeake Bay is the single most important wintering ground in North America for whistling swans (Bellrose 1976). Canada geese and black ducks also use the Bay area in winter. Aquatic grass beds provide spawning areas for estuarine-dependent fishes like striped bass, shad and herring and offer shelter for their young. Important submerged plants include pondweeds, redhead grass, eelgrass, wild celery, waterweed, naiads, muskgrasses and Eurasian milfoil.

Sea grass beds in the Bay nave been declining since the $1960^{\circ}$ s. According to a recent study (Stevenson, et al. 1979) in Maryland, submerged aquatic vegetation decreased by almost $65 \%$ from 1971 to 1978. A similar decline has also been observed in Virginia waters. At the mouth of the Susquehanna River, submerged grasses at a

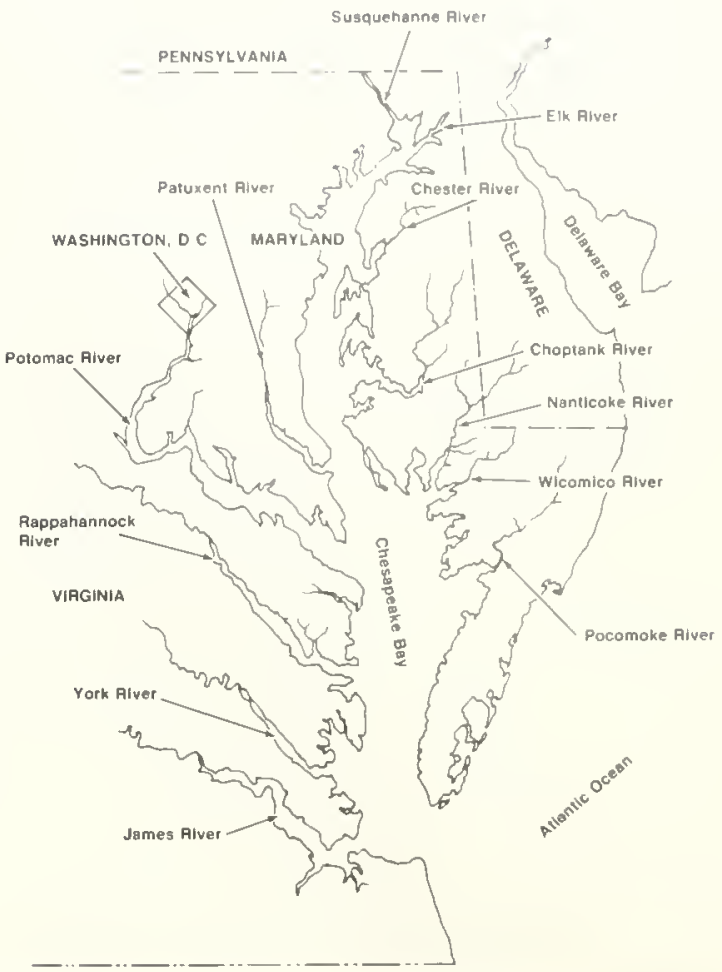

Fig. 35. Chesapeake Bay and its major tributaries

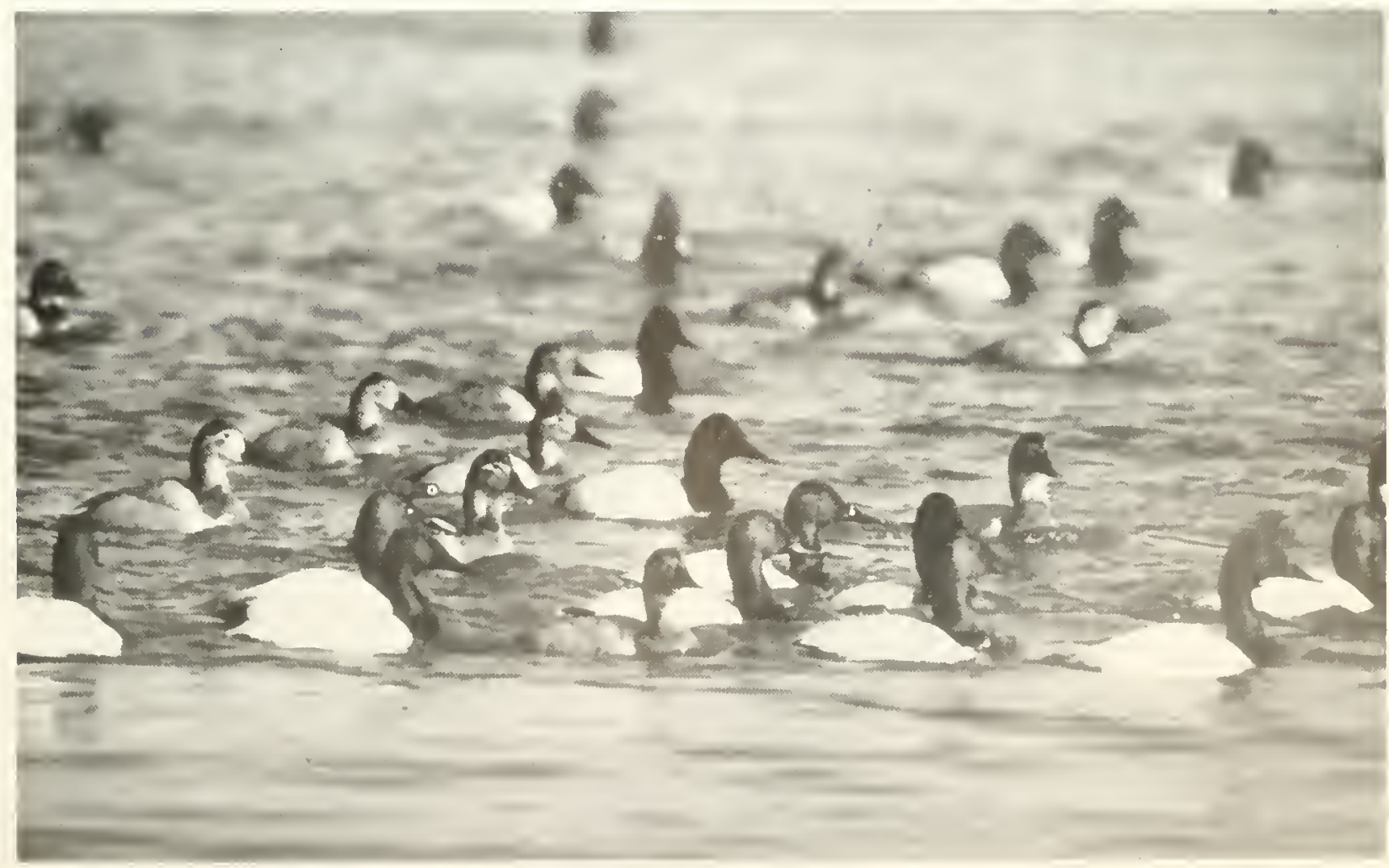

Fig. 36. Chesapeake Bay is one of the more importanl wintering areas for canvasbacks in North America. 
once prine waterfowl leeding area have virtually disappeared since 1971. Other areas have experienced declines in the numbers of plant species present. Since 1978, submerged aquatic vegetation appears to have stabilized. with a few areas even showing a slight increase (Orth and Moore 1981). Reductions in submerged vegetation have probably been the most important wintering habitat change which have led to declines in local populations of canvasbacks and redheads (Perry, et al. 1981). These changes point to a stressed ecological system.

Although the causes of this vegetation decline are hard to pinpoint, researchers suggest a combination of natural and human-induced factors. Natural stresses include overgrazing by carp and cownose rays. Hurricane Agnes. a general warming of Bay waters, and natural diseases. In June 1972, Hurricane Agnes hit the Bay region. Its heavy rainfall lowered salinity in Chesapeake Bay and buried numerous grass beds with sediment carried by runolf Human impacts on the submerged vegetation are largely from two general sources of water pollution: point and nonpoint sources. Point source pollution comes mainly from industrial and sewage treatment plant discharges. while nonpoint sources include failing septic systems. agricultural runoff or urban runofl. These sources cause increased turbidity and sedimentation, nutrient overloading, and chemical pollution which have reduced or eliminated aquatic beds from many areas. Channelization projects in bottomland hardwood lorested wetlands have undoubtedly contributed to the problem by accelerating the discharge of agricultural runoff and eroded soil into the Bay.

The problem of the Bay's submerged aquatic vegetation is receiving special attention from the U.S. Environmental Protection Agency (EPA) and others. EPA established a Chesapeake Bay program to address this problem. Future studies should increase our understanding of the causes of the decline of submerged aquatic vegetation and will hopefully lead to improved watershed management to restore and maintain a healthy Chesapeake Bay. Meanwhile, the governors of Maryland. Pennsylvania and Virginia have joined together to address water quality problems in the Chesapeake Bay watershed. Only through interstate coordination and action can the Bay's problems be solved.

\section{South Florida's Palustrine Wetlands}

South Florida encompasses a 9,000 square mile area of lakes, rivers and wetlands which extends from Orlando south to the Florida Keys. While the Everglades dominates this region, Big Cypress Swamp, the Kissimmee River and Lake Okeechobee are equally important. Freshwater runoff from this area helps maintain the salinity balance of estuaries which support $85 \%$ of South Florida's offshore fishery (Yates 1982). The wetlands are breeding grounds for many birds, notably wood and other ibises, roseate spoonbills, herons, egrets and Florida

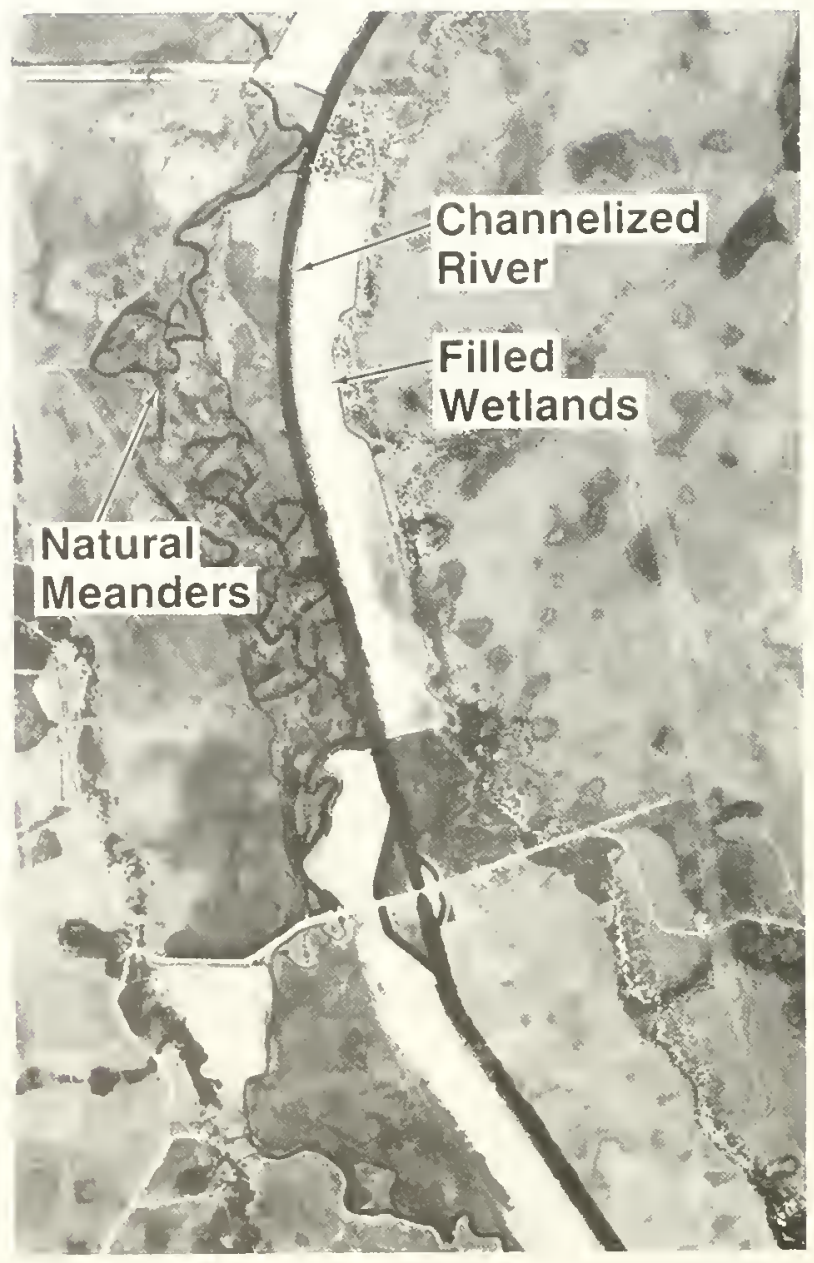

Fig. 37. Channelization of the Kissimmee River directly destroyed many wetlands and facilitated drainage of more than 100,000 acres of wetlands.

ducks. They also support winter populations of numerous waterfowl, especially lesser scaups, ringnecks, bluewinged teal, canvasbacks, and wigeons. Rare and threatened animals depend on these wetlands, including the Florida panther, American crocodile, manatee, brown pelican. Everglades kite and southern bald eagle. The Everglades National Park was established to protect these natural resources.

South Florida's waters and wetlands have been subjected to various uses for many years (Yates 1982). In the $1920^{\circ} \mathrm{s}$, large wetland areas were drained and converted to sugar cane farms. Severe floods in 1928, 1947 and 1948 stimulated a massive flood control project in South Florida. The Central and Southern Florida Flood Control Project, authorized by Congress, required the U.S. Army Corps of Engineers to construct a network of nearly 800 miles of new or improved levees and 500 miles of canals. 
This project completed drainage of the Kissimmee River wetlands, regulated Lake Okeechobee's water levels and drained and irrigated the Everglades Agricultural Area. Channelization directly destroyed 40,000 aleres of wetlands and facilitated drainage of more than 100,000 aeres of contiguous wetlands (Figure 37; Thompson 1983). By reducing floods, the flood control project also accelerated filling of wetlands for urban expansion of coastal eities, especially in Dade, Broward and Palm Beach Counties, as well as increasing agricultural conversion of wetlands (Figure 38). For example, between 1972 and 1980, Palm Beach County lost 23,76 acres of wetlands to agriculture and 655 acres to urban development (U.S. Fish and Wildlife Service 1982) for a $7 \%$ wetland loss in just 8 years.

Problems related to water supply have also resulted from this llood control project. Although three large inpoundments called "conservation areas" were constructed to maintain recharge of the Biscayne Aquifer and prevent salt water intrusion into public drinking water supplies, salt water intrusion remains a constant threat. Urban growth and agricultural development increase demand for water. Public wells have been constructed further west which have lowered the Everglades water table and have increased the flow of salt water into the Biscayne Aquifer. Besides public water supply problems, the flood control project has also seriously disrupted the natural hydrologic regine of the Everglades National Park. Levee L-29 completely blocked sheet flow of freshwater into the Park in 1963. After much controversy and public debate, the Corps of Engineers in 1970 agreed to release a minimum of 315,000 acre-feet of water annually (Yates 1982). Park officials estimate that at least twice this amount is needed and that the water must be distributed over a wider area and be released on a more natural regime. These changes are necessary to preserve the biological integrity of the Everglades National Park.

Wetland alterations in South Florida have created problems for many fish and wildlife species. Periodic discharges of freshwater from the conservation areas have disrupted fish nursery grounds in estuaries. Colonial wading bird populations have declined from about 1.5 million in 1935 to about 0.25 million today. Alligators have been eliminated from many areas and frog populations have been critically reduced from a commercial harvesting standpoint (Marshall 1981).

Possible effects of the Kissimmee River ehannelization and wetland drainage on local rainfall patterns have also been raised. Although quite controversial, some scientists have suggested that wetland drainage in South Florida has reduced the mist of evaporation and plant transpiration which triggers rainfall from sea breezes. This eondition may be responsible for recent severe droughts.

In 1976, the Florida legislature passed a mandite to restore the Kissimmee River. They recognized that channelization of this river among other things: increased the seriousness of water shortages and droughts, degraded water quality of Lake Okeechobee, eliminated vast acre- ages of wetlands, drastically reduced fish and wildlife populations and destroyed a beautiful, meandering river (Florida Conservation Foundation 1977). Ironically, the flood control project actually increased the potential for catastrophic floods and raised costs to ranchers and farm. ers. Florida's Save Our Rivers Aet of 1981 created state funds to purchase threatened wetlands. The Nature Conservancy, the Richard King Mellon Foundation, and Nittional Audubon Society have also been active in wetland acquisition. In 1983. Governor Graham announced a multi-million dollar "Save Our Everglades" program to restore the ecology of the Everglades, which includes acquisition of 250.000 acres of wetlands and improving hydrology (Thompson 1983). He also stressed the importance of Federal-state cooperation in achieving this goal. These efforts should be instrumental in preserving these fragile wetlands and their associated values.

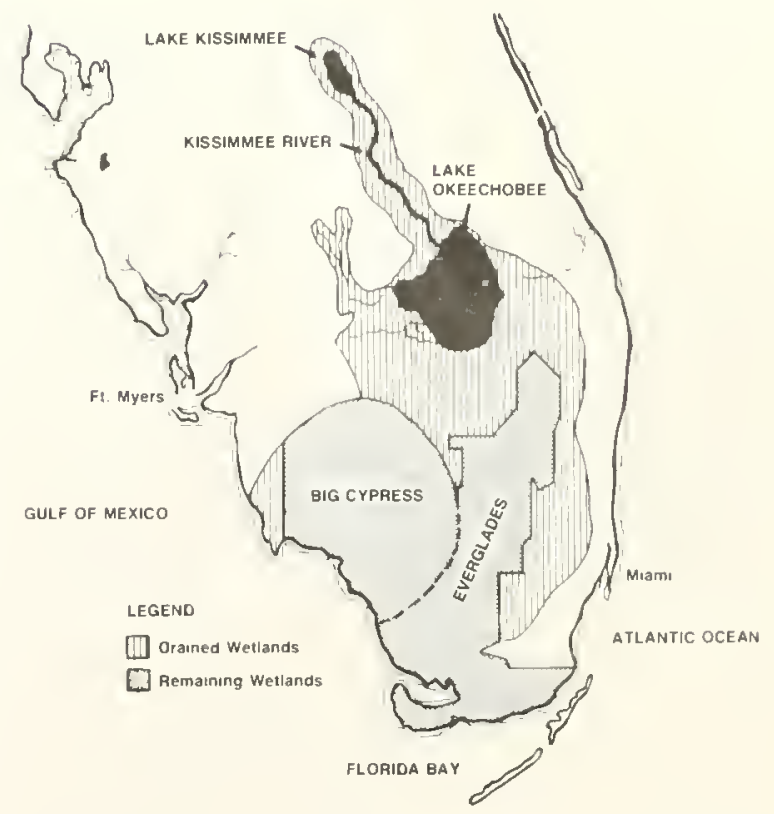

Fig. 38. Present extent of wellands in the Florida Everglades; former wellands are also shown (from Marshall t981). 


\section{Prairie Pothole Region's Emergent Wetlands}

Prairie potholes are the most valuable inland marshes for waterfowl production in North America (Figure 39). Although the Pothole Region accounts for only $10 \%$ of the continent's waterfowl breeding area, it produces $50 \%$ of the duck crop in an average year and more than that in wet years (Smith, et al. 1964). The Prairie Pothole Region extends from south-central Canada to north-central United States, covering about 300.000 square miles with roughly one-third in the United States. Due to glaciation thousands of years ago, the landscape is pock-nlarked with millions of pothole depressions, mostly less than two feet deep. These pothole wetlands serve as primary breeding grounds for many kinds of ducks including: mallard, pintail, wigeon, gadwall, shoveler, teal, canvasback, and redhead. For example, in a study area in northeastern South Dakota, researchers found an average of 140 ducks produced per square mile per year (Evans and Black 1956).

In North and South Dakota, pothole wetlands originally covered 7 million acres. Today, only slightly more than 3 million acres remain. Over half have been destroyed by agriculture. irrigation and flood control projects (Elliott pers. comm.). lowa has lost more than $99 \%$ of its natural marshes (Bishop pers. comm.). Approximately 9 million acres of potholes have been drained in Minnesota (Figures 40 and 41 ). Since pothole wetlands are surrounded by farmland, they have been drained to create additional cropland, mostly for wheat in the west and corn in the east. Drainage in the Dakotas is largely done by open ditching in contrast to both open ditching and tile drainage in Minnesota and lowa. These ditches drain into intermittent streams or highway right-of-way ditches. Highway ditches have been heavily used by local farmers to help drain wetlands. In western Minnesota alone, nearly 100,000 acres of wetland have been lost in this way (U.S. Fish and Wildlife Service 1975). In addition. stream channelization sponsored by Federal flood control projects, such as the small watershed protection and flood prevention program (P.L. 83-566), have led to accelerated wetland drainage in the Pothole Region as they have elsewhere in the U.S. (Erickson, et al. 1979). Drainage data for the Dakotas and Minnesota obtained from the U.S. Department of Agriculture's Production and Marketing Administration show that 188,000 acres were drained with Federal assistance in 1949 and 1950 alone. Countless other acres were privately drained at the same time (Figure 42). Pothole wetland losses are estimated at more than 33,000 acres yearly (Haddock and DeBates 1969). Among the remaining wetlands, the drier

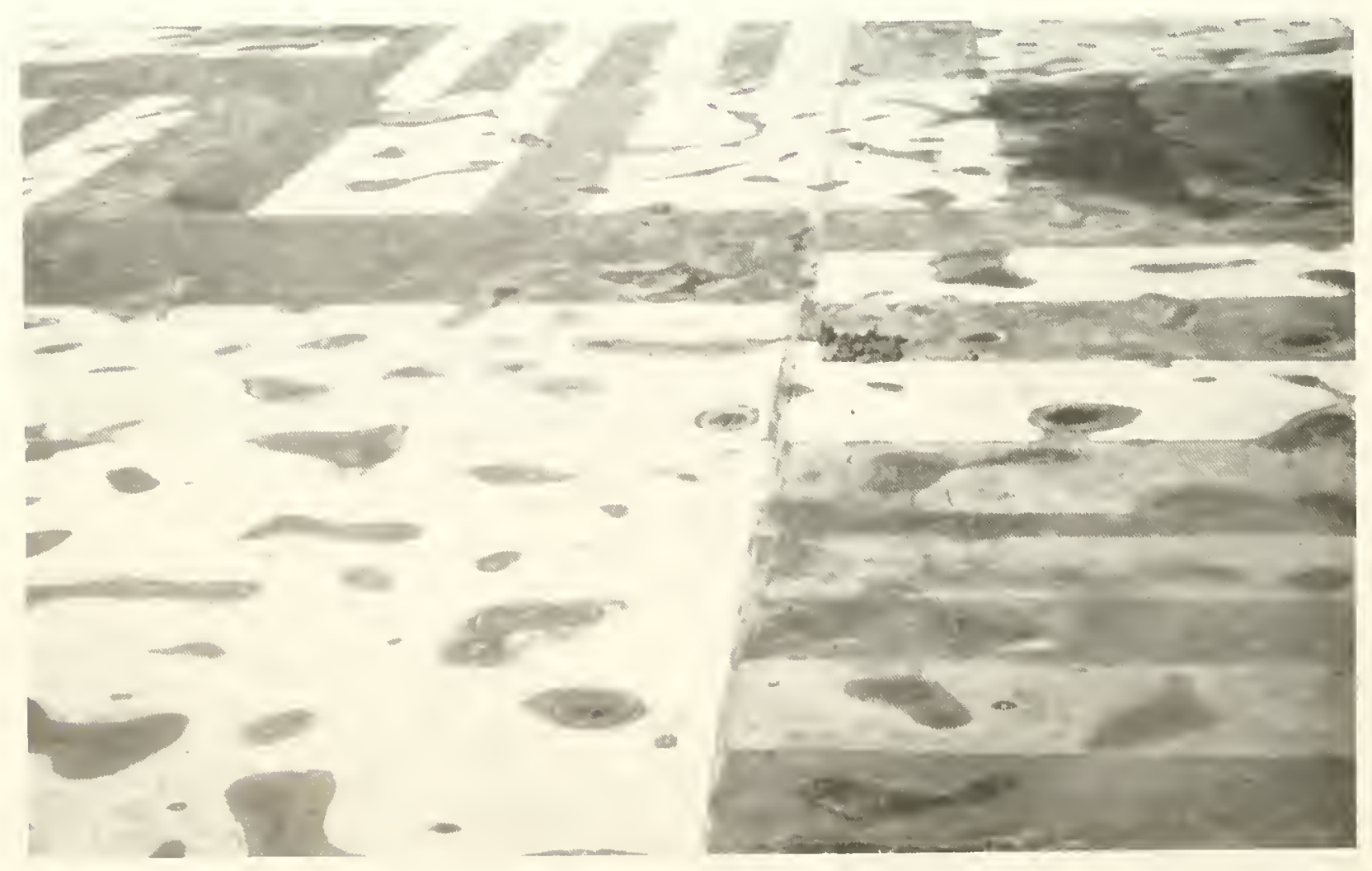

Fig. 39. Prairie pothole wetlands are the Nation's most valuable waterfowl production areas, (a) aerial view of potholes and (b) blue-winged teal 
ones (i.e., temporarily flooded) are often tilled during dry periods of the natural hydrologic cycle.

Drought in the Prairie Pothole Region is largely responsible for declines in waterfow'l breeding populations. Drainage of potholes may have a similur but more lasting eflect on breeding waterfowl. Each pothole drained leads to a further concentration of the breeding waterlowl population. This could result in decreased productivity, reduced size of the breeding population. and/or increased likelihood of diseases like avian cholera and botulism. Wetland drainage also destroys habitats important to invertebrates used as food by breeding waterfowl like pintail and blue-winged teal (Krapu 1974: Swanson, et al. 1974). Moreover, drainage eliminates the flood storage value of pothole depressions. thereby increasing flooding problems as in the James River basin of North Dakota (Sidle 1983).

Agricultural activities on upland adjacent to potholes have also adversely impacted waterfowl production. Upland grasses bordering wetlands provide valuable nesting cover for mallard and other dabbling ducks. Conversion of rangeland to cropland, which destroys these nesting areas, has been accelerating. Between 1965 and 1975 , approximately one half of the rangeland in the Coteau du Missouri counties of North Dakota were converted to cropland (U.S. Fish and Wildlife Service 1984)

Excavation of ponds (dugouts) in pothele uetlands is also a problem. Out of an estimated 55,855 dugrouts in eastern South Dakota in 1976, 77\% were in wetland bit sins or streams (McPhillips, et al. 1983). Excavation and spoil deposition alter wetland hydrology which maly re duce waterfowl usage. More research is needed to evaluate potential impacts

The Fish and Wildlife Service has been active in preserving Prairie Pothole wetlands through acquisition. easement. and other programs. Recently, wetland acquisition in North Dakota was stopped for several years by state law. Due to a U.S. Supreme Court ruling against the state for this action, the Service's wetland acquisition is being resumed. The Federal government generally regulates filling of pothole wetlands 10 acres in size or larger, yet smaller isolated wetlands are largely unprotected. A $198+$ settlement agreement between the Corps of Engineers and various environmental groups (National Wildlife Federation v. Marsh) provides an opportunity to improve regulation of agricultural conversion of pothole wetlands. The Service's acquisition and easement program and improved Federal regulation are needed to maintain valuable waterfowl producing wetlands, since pressures continue to convert such areas to agriculture.

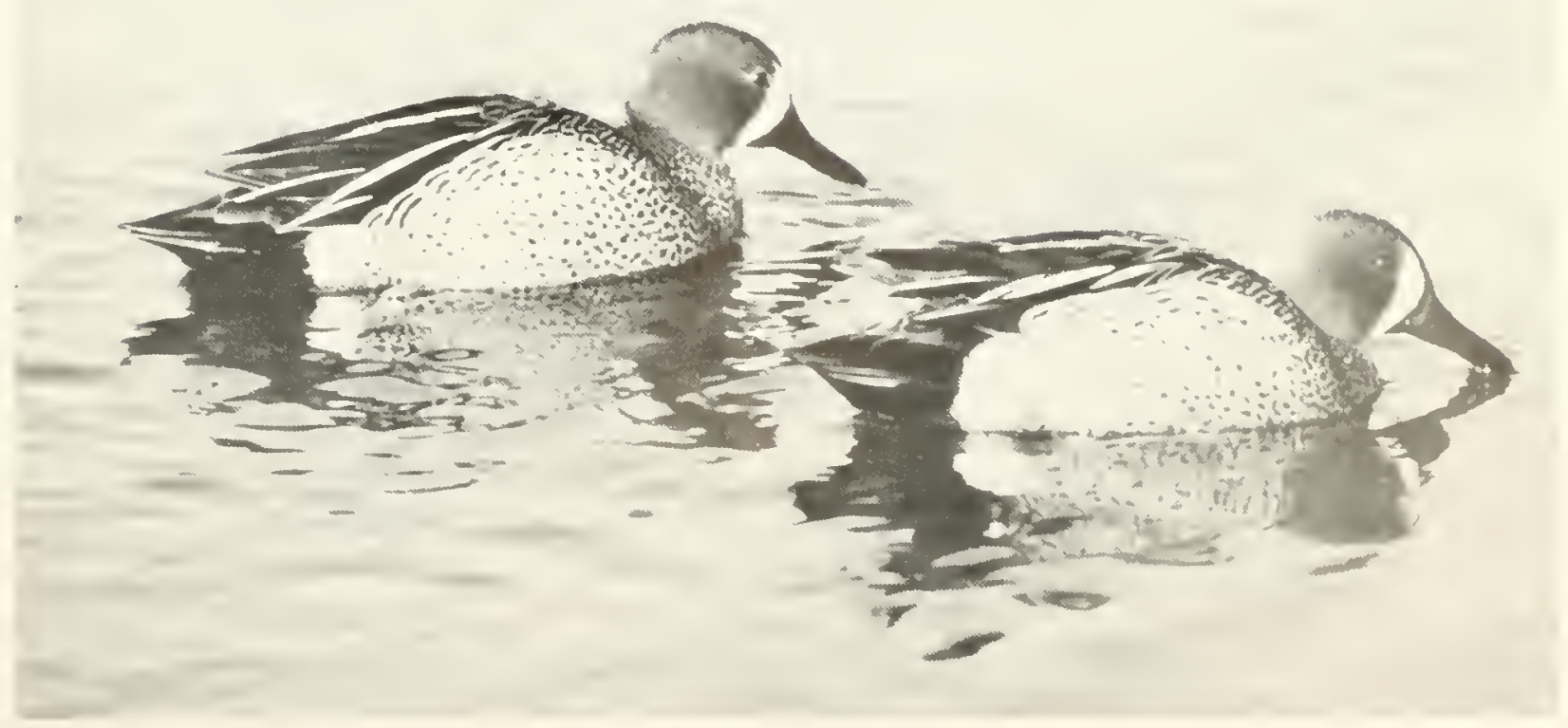




\section{ORIGINAL WETLANDS OF MINNESOTA}

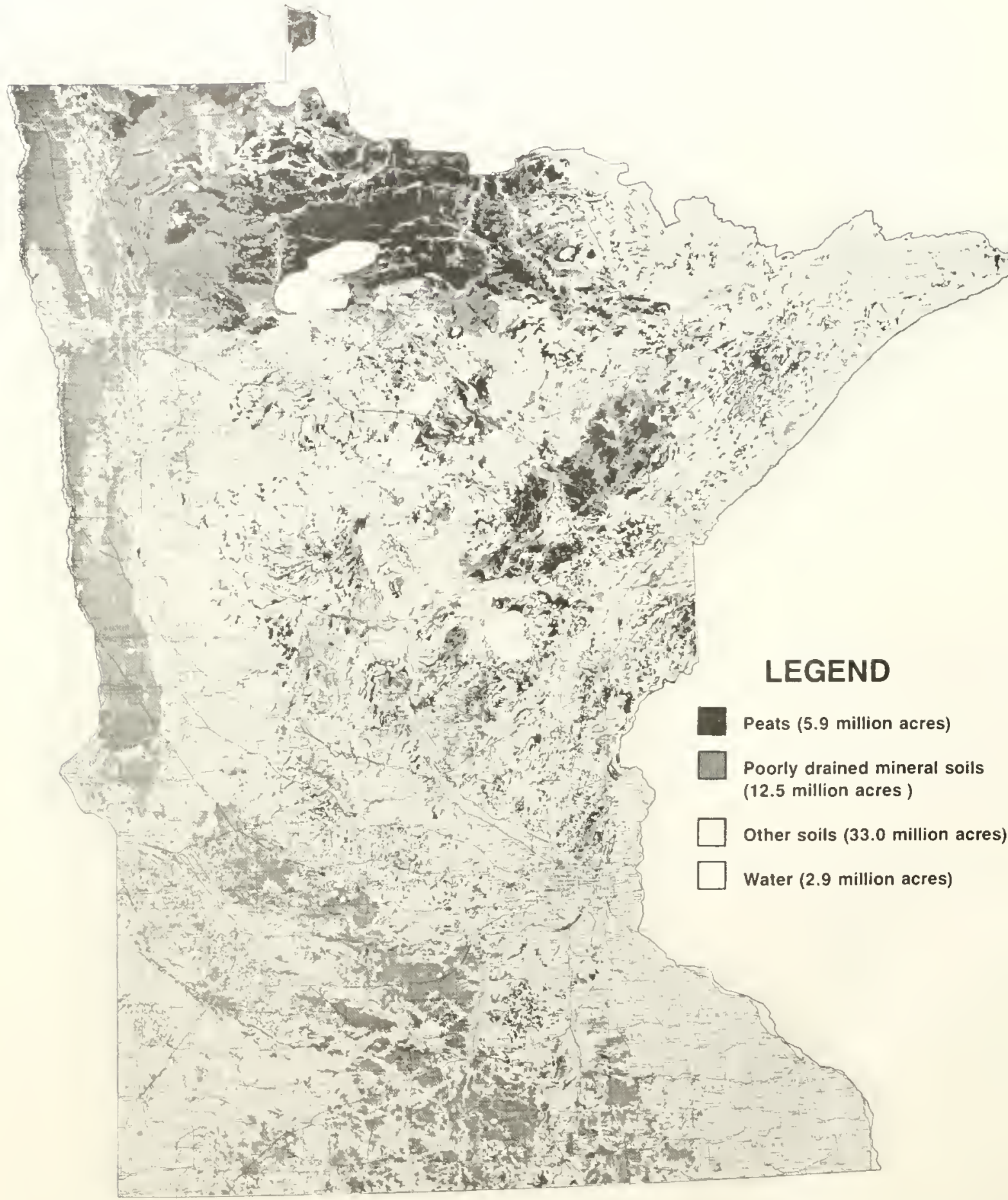

Fig. 40. Original extent and distribution of Minnesota's wetlands (University of Minnesota 1981) 


\section{EXISTING WETLANDS OF MINNESOTA}

Fis

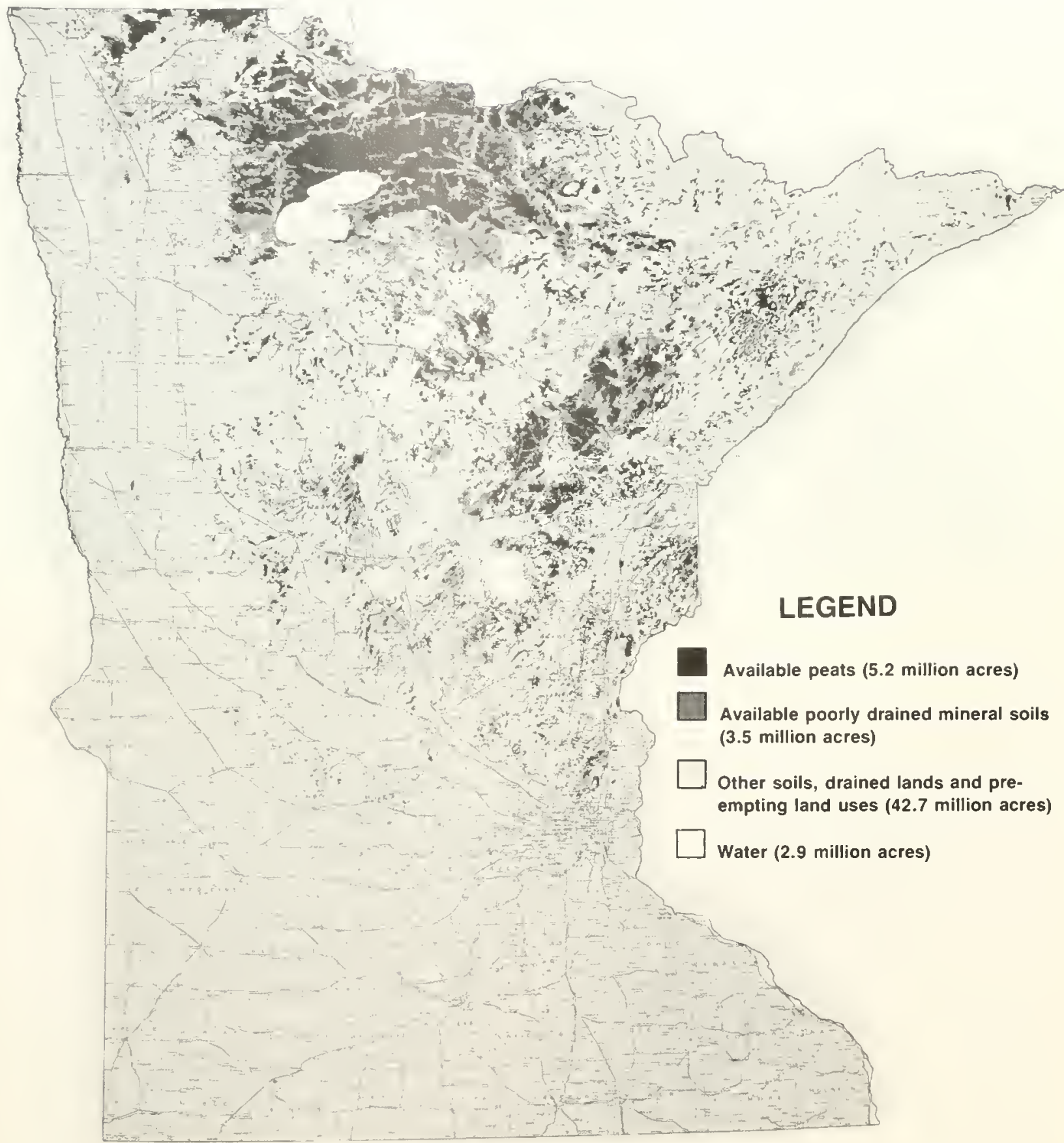

Fig. 41. Present extent and distribution of Minnesota's wetlands (University of Minnesota 1981). Nine million acres of poorly drained soilspothole wetlands-have been converted to agriculture 


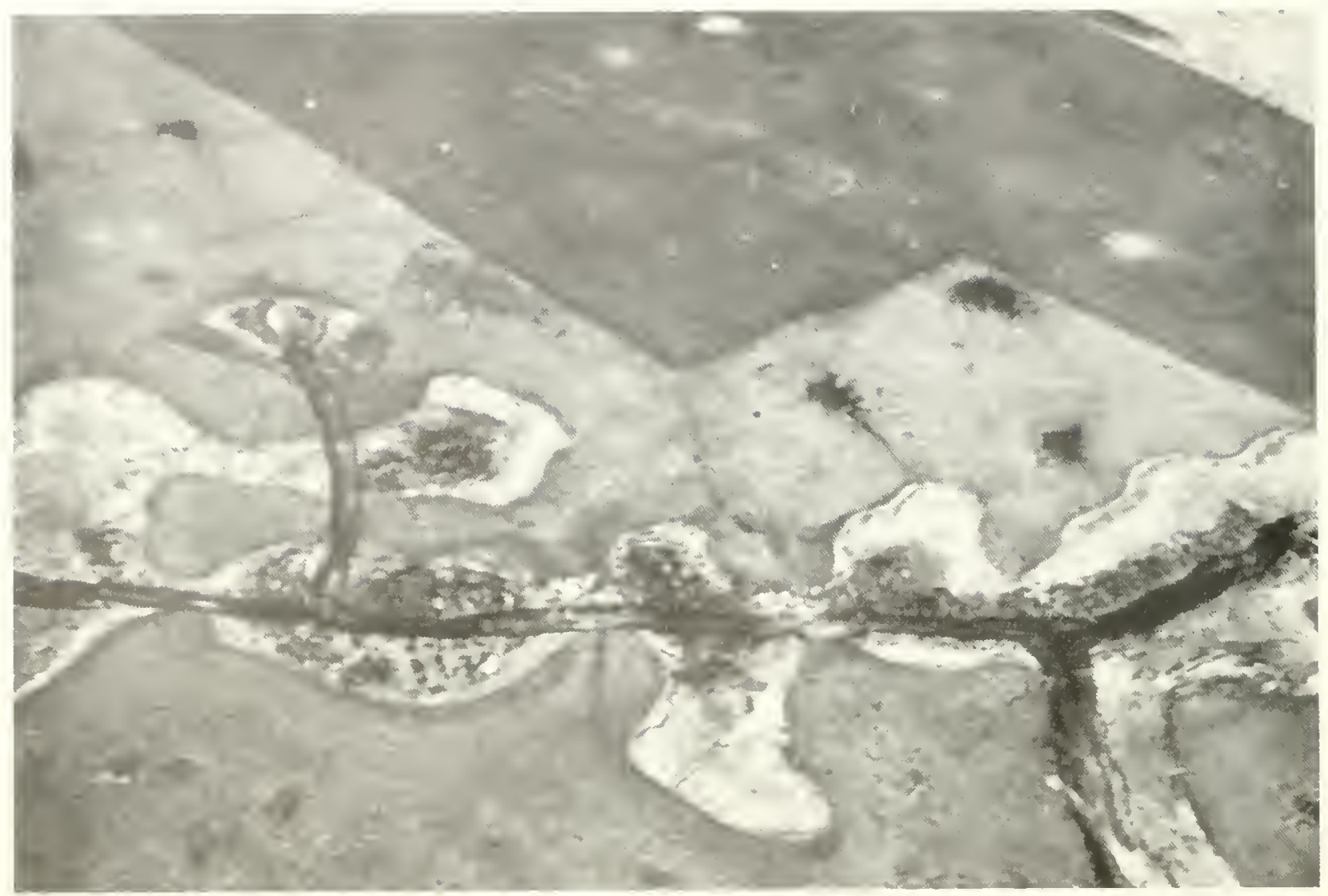

Fig.42. Prairie pothole wellands continue to be drained for agriculture.

\section{Wetlands of Nebraska's Sandhills and Rainwater Basin}

Wetlands within the Sandhills and Rainwater Basin of south-central Nebraska are important to migrating sandhill cranes and waterfowl in the Central Flyway. About 2.5 million ducks and geese move through the Rainwater Basin each spring. Ninety percent of the mid-continent's white-fronted geese stage in wetlands of the Basin and central Platte each spring. Pheasants also depend on wetland vegetation for nesting and hrood habitat (Farrar 1982). Eighty percent of the continent's population of sandhill cranes depend on wetlands along 70 miles of the Platte and North Platte Rivers as staging areas during spring migrations (Figure 43). Whooping cranes, an endangered species, also roost in broad reaches of the Platte River's channels (U.S. Fish and Wildlife Service 1981).

The Nebraska Sandhills Region is the largest sand dune formation in the western hemisphere covering approximately 20,000 square miles. Formed primarily by wind action, the Sandhills consist of stabilized sand dunes, exposed groundwater lakes in the valleys, and perched mineralized lakes on poorly drained soils. The grassland economy of the Sandhills is primarily one of cattle grazing. Large acreages of subirrigated meadows with water tables close to the surface offer great potential for increased grazing and hay production through development of level ditching. Wetland destruction in the Sandhills has accounted for over 28,000 acres or $15 \%$ of the original wetlands (Nebraska Game and Parks Commission 1972). Wetland loss has resulted from drainage, filling for pivot irrigation, and reduced groundwater levels from deep well irrigation.

Decreases in riverflows of the Platte River by upstream diversions for consumptive uses in Colorado. Wyoming and western Nebraska have reduced channel width by 80 $90 \%$ in many areas. This condition has promoted growth of woody vegetation on former channel bars and islands. Sandhill cranes prefer roosting in shallows and sandbars where the channel is at least 500 feet wide and strongly avoid narrower channels. Reduction in natural channel width and increased growth of woody vegetation have caused crowding at remaining roost sites. This situation increases crane susceptibility to catastrophic losses due to 

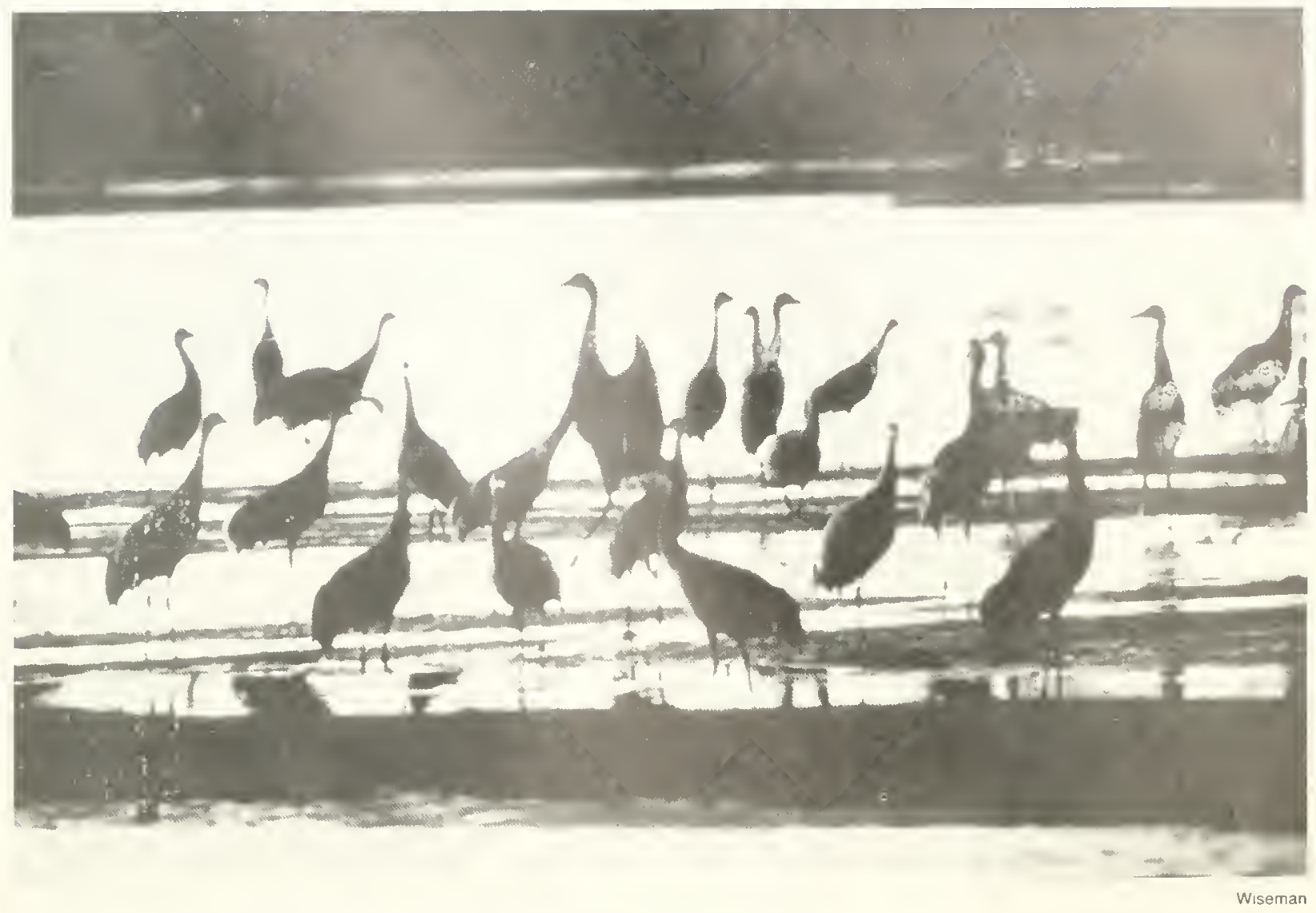

Fig. 43. Sandhill cranes on a Ptatte River roost at sunrise

severe storms and disease. If the trend continues, sandhill cranes may shift to the Rainwater Basin where avian cholera is already a serious problem. Native grasslands along the rivers have also declined. These areas provide important food for the migrating cranes (U.S. Fish and Wildlife Service 1981).

The Rainwater Basin includes parts of 17 counties. roughly 4.200 square miles in extent. Wetlands formed in depressions underlain by clay on the rolling plain. Originally 4,000 marshes totaling 94,000 acres existed. Wetland destruction accelerated after World War II due to improved earth-moving equipment and deep well irrigation. Agriculture intensified in the Basin with the help of Federal funds and technical assistance for wetland drainage. By the late 1960 's, $18 \%$ remained and in 1981 . less than $10 \%$ survived. Nine out of every ten wetlands have been drained or filled. Of those remaining, only $43 \%$ are protected by state or Federal wildlife agencies.

Losses of Basin wetlands have forced ducks and geese to concentrate in the remaining wetlands. In 1980. about 80.000 waterfowl died due to avian cholera. This was the second largest cholera die-off reported in the country. During dry years with late winter storms, birds are forced to crowd in Basin wetlands, setting the stage for large dieoffs. Waterfowl breeding populations have also been affected by wetland destruction. By 1975, the duck breeding population declined so much that the Nebraska Game and Parks Commission discontinued its aerial breeding bird survey.

Efforts to protect remaining wetlands have recently been weakened. The Water Bank Program which provides payments to landowners preserving important waterfowl wetlands has been funded at lower levels. Wetland protection under the Clean Water Act of 1977 has been reduced through regulatory changes. New regulations which may strengthen protection will, however, be proposed this year. Legal disputes between the Fish and Wildlife Service and others over water rights have affected management of 15.507 acres of waterfowl production areas in the Rainwater Basin. Along the Platte and North Platte Rivers, action is needed to protect native grasslands near river channels and to maintain channel 
widths of 500 feet or more for suitable crane roost sites during migration. Acquisition and conservation easements are useful tools.

\section{Forested Wetlands of the Lower Mississippi Alluvial Plain}

The bottomland hardwood forests of the lower Mississippi tloodplain are among the Nation's most important wetlands. They are prime overwintering grounds for many North American waterfowl, including 2.5 million of the 3 million mallards of the Mississippi Flyway', nearly all of the 4 million wood ducks and many other migratory birds. Numerous finfishes depend on the flooded hardwoods for spawning and nursery grounds. These wetlands also support many other wildlife, including deer. squirrel, raccoon, mink, beaver, fox and rabbit. They also play a vital role in reducing flooding problems by temporarily storing large quantities of water and by slowing the speed of flooding waters. In the process, these wetlands remove chemicals from the water such as fertilizers and pesticides and trap soil eroding from nearby farmlands.

Originally, the Mississippi Alluvial Plain included nearly 24 million acres of bottomland forested wetlands. By 1937, only 11.8 million acres or $50 \%$ of these remained. Today, there are less than 5.2 million acres left, roughly $20 \%$ of the original acreage (Figure 44: MacDon-

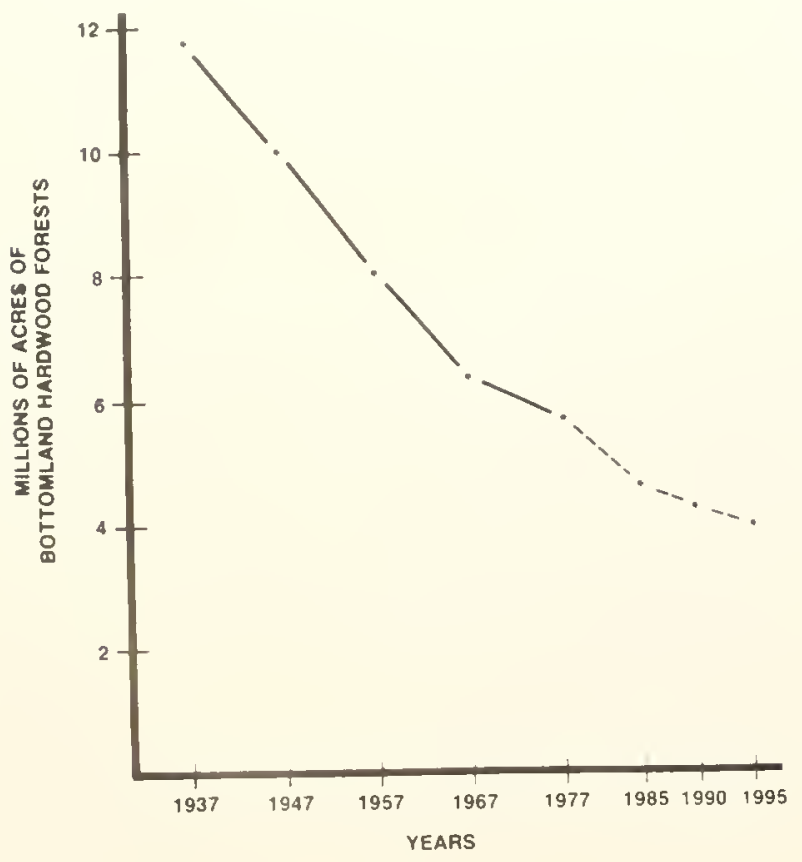

Fig. 44. Actual and projected losses in bottomtand forested wetlands of the lower Mississippi Alluvial Plain (from MacDonald, et al. 1979). ald. et al. 1979). Over half of this wetland is in Louisiana. with large amounts also in Arkansas and Mississippi. These forested wetlands have been cleared and drained for crop production (Figure 45). Federal flood control projects and small watershed projects have accelerated wetland conversion to cropland. especially from the 1950 's to the present. An estimated $2 \%$ of the remaining bottomland forests are lost annually.

Historically, cotton and corn were the primary crops raised on former bottomlands, but since the nid- 1950 's. soybeans have dominated. In 1977. cropland acreage in soybeans amounted to more than the combined acreage of the four other principal crops - cotton. wheat, rice and corn. Soybeans have major advantages over the other crops: (1) they have a very short growing season, so they can be planted in areas that are flooded till late June, and (2) they can be planted in a variety of soil conditions. Other crops, like cotton, require better drained soils than soybeans or rice. Heavy foreign demand for soybeans has made it the most lucrative cash crop. Traditionally, natural stands of bottomland hardwood forests were cut for timber. Recently, in an effort to maximize timber production, cottonwood and other silviculture plantations have been established to a limited extent. However, the economics of hardwood production cannot compete with farm crops. where they can be grown. The net economic return per acre is twice as high for farmland as for forest. Thus, conversion of bottomland hardwoods to cropland can be expected to continue in the Mississippi Alluvial Plain as well as elsewhere in the Southeast. These losses seriously threaten some wildlife populations and increase the frequency of damaging floods like the April 1983 floods that caused millions of dollars of damage in Louisiana and Arkansas.

The Federal Clean Water Act can be instrumental in regulating conversion of bottomland hardwood forests to agricultural uses. A 1979 U.S. District Court decision (Avoyelles Sportsmen's League v. Alexander) stated that a Section 404 permit is required for land clearing of wetlands for agriculture. Subsequently, the Corps of Engineers took a conservative position and regulated land clearing only in the Western District of Louisiana. On September 26, 1983. the Fifth Circuit Court of Appeals decision (Avoyelles Sportsmen's League v. Marsh) affirmed the district court's opinion by rejecting the contention that land clearing is a normal farming activity exempt from Section 404 permit requirements. This decision provides the legal framework for protecting remaining bottomland wetlands as well as other inland wetlands subject to agricultural conversion. In early 1984, an out-of-court settlement agreement on a U.S. District Court case (National Wildlife Federation v. Marsh), among other things ordered the Corps of Engineers to issue a regulatory guidance letter regarding the Avoyelles Sportsmen's League decisions. The future outcome of these decisions should lead to improved wetland protection under the Clean Water Act. 

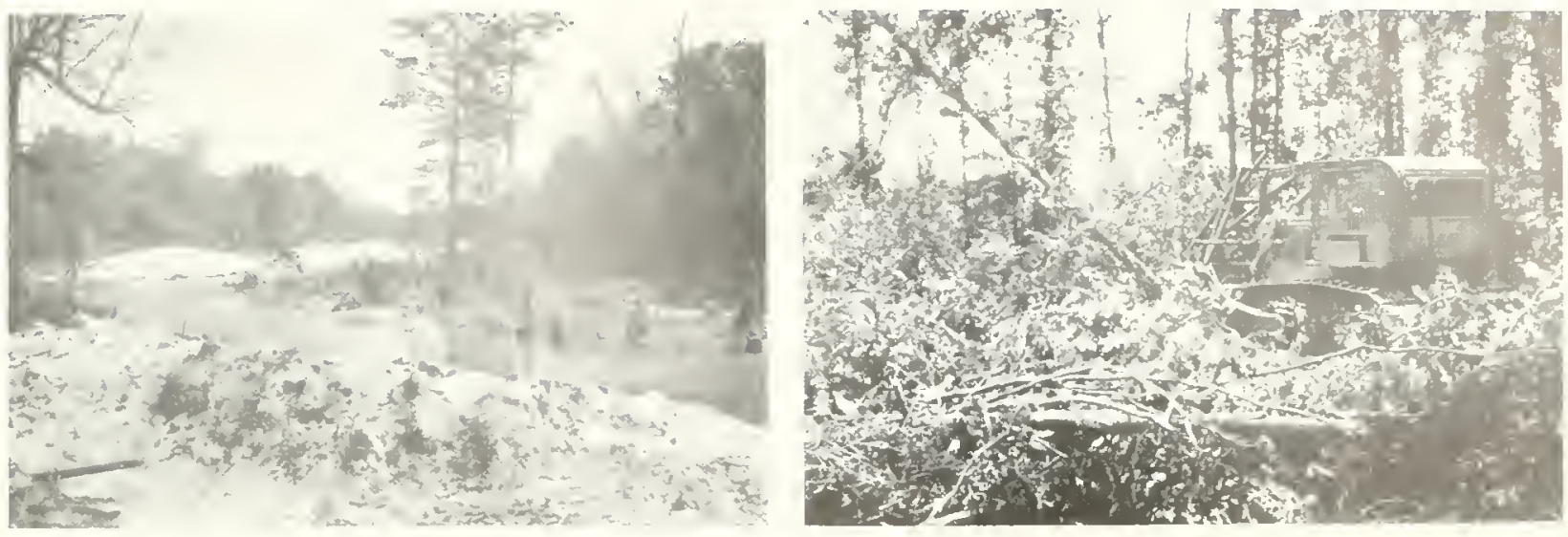

USFWS

B

LSFWS

Fig. 45. Boltomland wetlands are berng channelized. clearcut and converted to agricultural uses in many areas of the Southeast, (a) channelization and (b) clearcutting

Besides improved regulation, acquisition of bottomland hardwood forests in the Lower Mississippi Alluvial Plain is needed to protect the remaining wetlands. Accelerated acquisition efforts by the Service, the State of Louisiana, the Nature Conservancy and others are important steps to preserving these forested wetlands.

\section{North Carolina's Pocosins}

Along the Southeastern Coastal Plain, numerous evergreen forested and scrub-shrub wetlands called "pocosins" are found (Figure 46). Pocosins lie in broad. flat upland areas away from large streams. Their vegetation consists of a mixture of evergreen trees including pond pine. loblolly bay, red bay and sweet bay with shrubs, including titi, zenobia, fetterbush, wax myrtle, and leath-

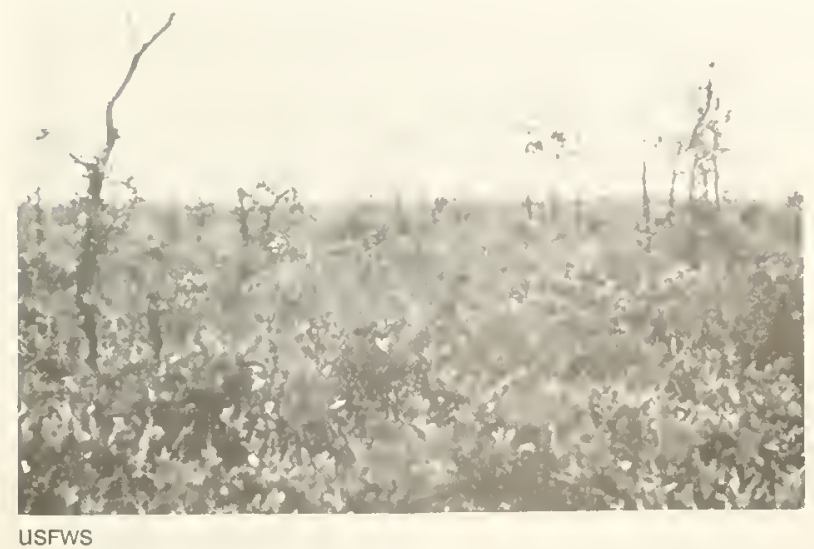

Fig. 46. Most of the Nation's pocosin wetlands occur along the coastal plain of North Carolina. erleaf. Seventy percent of the Nation's pocosins are in North Carolina, where they alone comprised about 2.2 million acres or half of the state's freshwater wetlands in 1962 (Richardson, et al. 1981).

Although pocosins are not essential for any wildlife species throughout its range, they do provide important habitat for many animals, especially black bear along the coast (Monschein 1981). For example, the Dismal Swamp is reported to be the last refuge for bears in coastal Virginia. More importantly, pocosin wetlands in coastal North Carolinta are closely linked with the riverine and estuarine systems (Richardson 1981: Street and McClees 1981). They help stabilize water quality and balance salinity in coastal waters. This is especially important for maintaining productive estuaries for commercial and recreational fisheries.

Historically, forestry and agriculture have had important influences on pocosins. During the past 50 years, forestry uses of pocosins have increased and today about $44 \%$ of North Carolina's pocosins are owned by major timber companies (Richardson, et al. 1981). While some pocosins were drained and converted to pine plantations or agriculture prior to the early 1960 's, most of the commercial development is more recent (Figure 47). Since 1970. timber companies have transferred nearly 500.000 acres to large-scale agriculture. Agricultural drainage has focused on the Albemarle-Pamlico peninsula where large corporate farms own 400,000 acres of pocosins. In addition to land clearing and extensive ditching. farming in these former wetlands requires adding fertilizers and lime. For example, 4 to 8 tons of lime must be added to each acre of new agricultural land, with one additional ton added every three years to keep former pocosin soils fertile (McDonald, et al. 1983). Runoff from these farmlands degrades water quality of adjacent estuaries. Changes in nutrient loading and salinity patterns of adjacent estuaries have been observed (Barber, et al. 1978). These changes may adversely impact fish nursery grounds. 


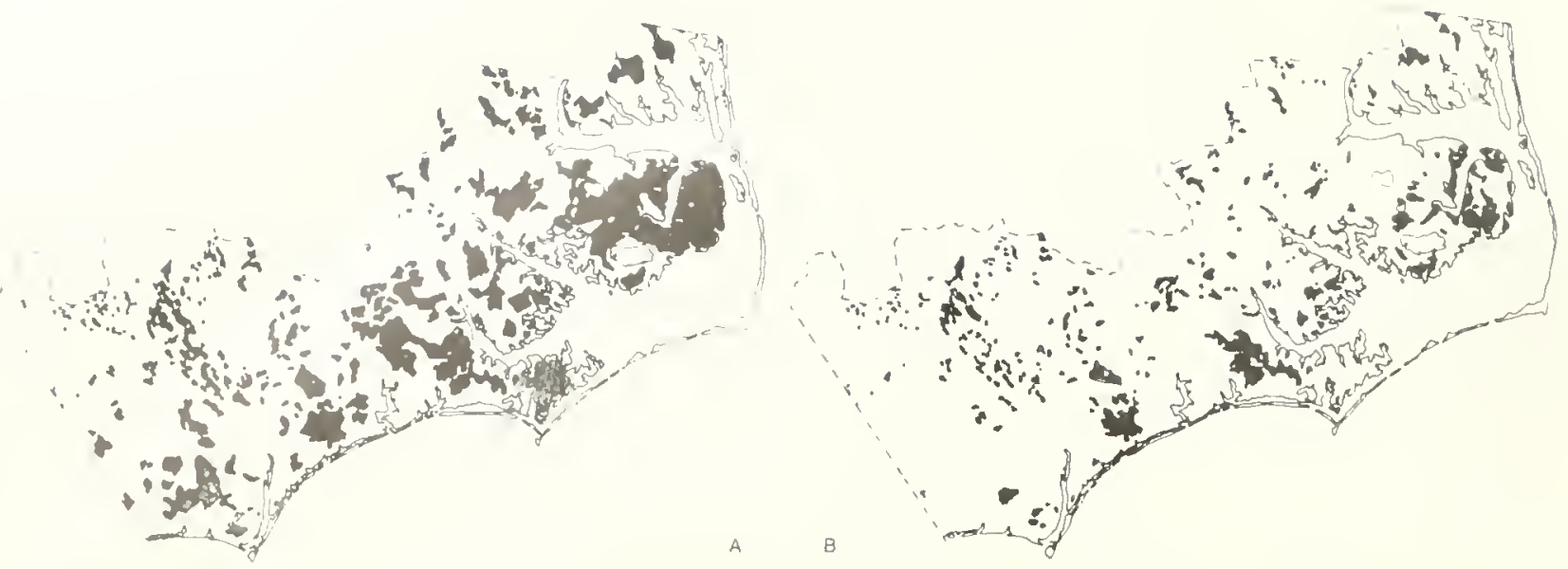

Fig. 47. Comparison of the extent of natural or only slighily modified pocosins in North Carolina, (a) early 1950 's and (b) 1980 (from Richardson 1981).

Although forestry and agricultural uses of pocosins continue, peat mining represents a new threat to these wetlands. Peat deposits about four leet thick generally exist in coastal North Carolina. Interestingly enough. some of the large agricultural corporations which own many pocosins are already involved in peat mining operations. On December 22. 1982, the U.S. Synthetic Fuels Corporation endorsed Federal subsidies for a $\$ 576$ million synfuel project in North Carolina. This project would remove peat from 15,000 acres of pocosins to produce methanol fuel and the land would subsequently be converted to farmland. This practice of peat mining and agriculture has been conducted for years in northern states like Minnesota.

About 2.5 million acres of pocosins once existed in North Carolina (Richardson, et al. 1981). Today, nearly 1 million acres survive in their natural condition. Thirtythree percent of the original pocosins was converted to agriculture or managed forests, while $36 \%$ was partially drained or cleared or planned for development. Federal wetland protection efforts through the Clean Water Act have been inconsistent to date. In September 1983, the Corps of Engineers was sued by various environmental groups (National Wildlife Federation $v$. Hanson) over the Corps ${ }^{*}$ failure to take jurisdiction over a large pocosin. The outcome of this court case may establish guidelines for future protection. If the present trend continues, however, we can expect that many pocosins will be lost in the near future. Moreover, a predicted change in estuarine salinity patterns may adversely affect valuable fish and shellfish nursery grounds and North Carolina's multimillion dollar commercial fishery.

\section{Western Riparian Wetlands}

Lands within the 100 year floodplain and along the margins of ponds and lakes in the arid and semiarid re- gions of the country (e.g., Arizona. New Mexico. Utah. Nevada, Colorado, California, and eastern Oregon and Washington) are commonly called riparian ecosystems. They include both wetlands along streams and other waterbodies, and uplands on floodplain terraces. Existing information on the extent of this resource does not make a clear distinction between wetland and upland because the system as a whole is so important. However, loss of riparian habitats in general serves to reflect trends in associated wetlands.

Riparian ecosystems provide abundant food, cover and water for resident and migrating animals (Figure 48). These thin ribbons of vegetation along streams and lakes support a disproportionately large variety of wildlife. Woody vegetation is used for nesting by birds and for food and shelter by various mammals. Mule deer migrate along streams between high elevation summer ranges and low elevation winter ranges (Thomas, et al. 1979). Cotronwood and willow wetlands are the prime bird habitats in the West (Anderson. et al. 1977). Migrating birds follow the Rio Grande corridor in the spring and fall and riparian wetlands are very important to these birds (Wauer 1977). Along the Lower Verde River in Arizona, 166 bird species frequented riparian habitats, including the endangered bald eagle and endangered Yuma clapper rail (McNatt, et al. 1980).

Unfortunately, riparian ecosystems have been mistreated by man to the point where we can safely say that they represent the most modified land type in the West. Many riparian forests have been converted to cropland and tame-grass prairie. Others have been badly overgrazed by livestock. Heavy grazing has destroyed understory vegetation and has prevented regeneration of riparian vegetation in many places. In Arizona, dam construction on rivers poses the greatest threat to remaining riparian lands (Todd 1978). Pumping of groundwater for irrigation, municipal and industrial uses has lowered the water table in many areas, drying up riparian wetlands 


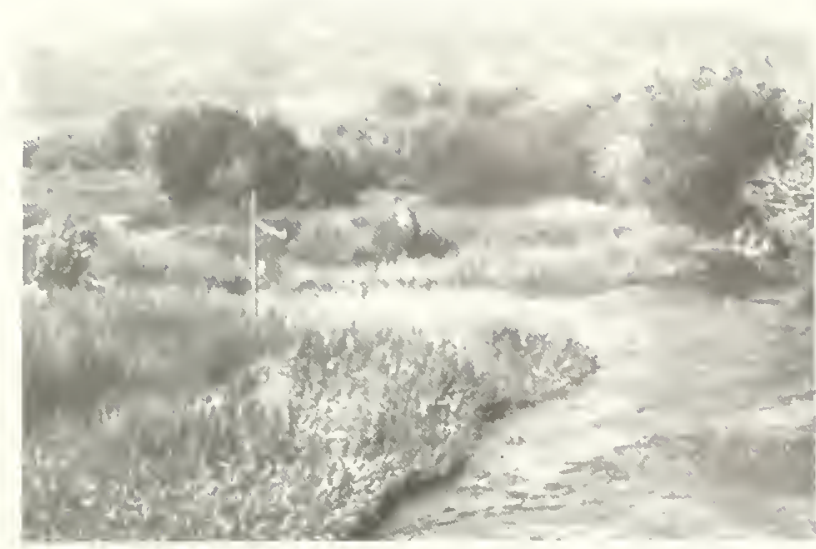

USFWS

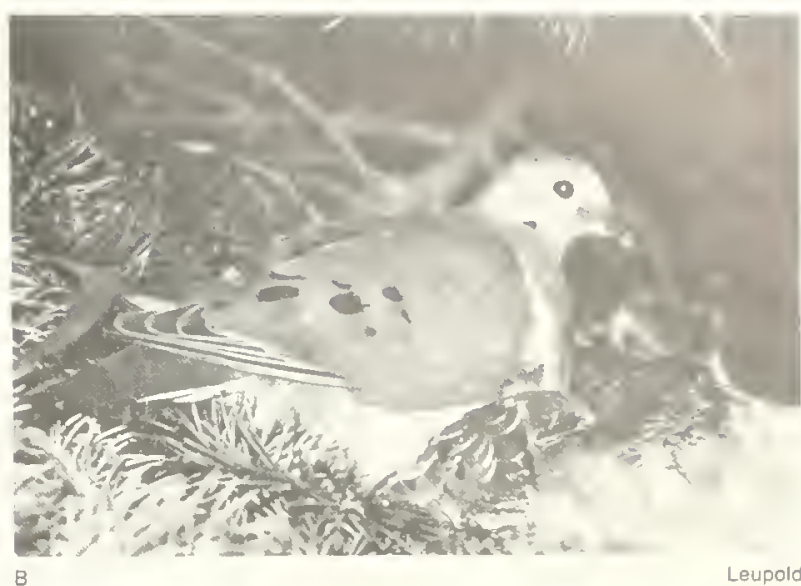

Leupold

Fig. 48. Riparian wellands along rivers and lakes are important to many types of wildlife in the West, (a) riparian wetland and (b) mouming dove.

and/or changing plant species composition.

The magnitude of riparian forest losses is alarming. For example, cottonwood communities along the Colorado River in Arizona have been reduced by $44 \%$, while in Colorado more than $90 \%$ of the river's riparian habitats were destroyed (Ohmart. et al. 1977). Only $2 \%$ of the original riparian forests along the Sacramento River in California remain (McGill 1975, 1979). In Oklahoma. Rush and Wildhorse Creeks in the Washita watershed experienced a $93 \%$ and $84 \%$ reduction in bottomland forests between 1871 and 1969 (Barclay 1980). Today, no natural wetlands exist within their floodplains.

Flood control projects, supported by Public Law 566. have reduced flood frequency and magnitude. This, in combination with channelization. has created drier conditions which may be the main factor for lower abundance of amphibians, reptiles, birds and mammals on channelized sites (Barclay 1978). Besides direct losses of habitat. the quality of remaining riparian lands is changing due to water quality degradation. reduced streamflow, and the invasion of saltcedar, an exotic tree of lower wildlife value (Ohmart, et al. 1977).

Because these riparian zones are of such tremendous value to wildlife. it is incumbent upon public agencies to treat them with a preservationist attitude. When a water project does extensive damage to a riparian area, there should be every effort made to mitigate that damage. either by planting of riparian species in nonvegetated riparian areas or by acquisition and enhancement of existing riparian zones.

\section{Urban Wetlands}

Wetlands near urban centers are under increasing development pressure for residential housing. industry, and commercial facilities. Rising population and economic growth create high demand for real estate in suburban localities. Northern New Jersey is greatly affected by neighboring New York City and thus serves as a good example of the urban impacts on wetlands.

The proximity of northern New Jersey to New York City has hastened development of its natural resources for urban and industrial uses. As suitable upland becomes exhausted, pressure intensifies to develop wetlands for residential housing, manufacturing plants, business office complexes and similar uses. In many communities, inland wetlands represent the last large parcels of open space. They often are also the final haven for wildlife in an increasing urban environment. Animal diversity is generally greater in inland wetlands than in other inland areas.

With accelerating development of adjacent uplands. the role of inland wetlands in flood protection and water quality maintenance becomes critical. Urban and industrial development increases the amount of surface water runoff from the land after rainfalls. This raises flood heights and increases flow rates of the rivers, thereby increasing the risks of flood damages. In the Passaic River watershed. annual property losses to flooding approached $\$ 50$ million in 1978 (U.S. Army Corps of Engineers 1979). Increased runoff brings with it various substances that degrade water quality, such as fertilizer chemicals, grease and oil, road salt, and sediment. Effluent from some sewage treatment plants built to handle the needs of growing communities also reduces water quality. By passing through wetlands, a type of cleansing action takes place as many pollutants are removed from the water and retained or utilized by the wetlands.

Inland wetlands in certain instances function as recharge areas. This is especially true in communities where groundwater withdrawals are heavy. Thus, inland wetlands may be essential to preserving public water supplies. This value is particularly important considering recent severe water shortages in northern New Jersey.

Inland wetlands of northern New Jersey are vulnerable 
to development for several reasons including: ( 1 ) in many cases, they represent the last large tracts of open land. (2) increased population growth in the New York melropolitan area has raised land values and demand for real estate. (3) relatively new interstate highways have improved access to many areas which has increased development opportunities, (4) most wetlands are zoned for light industry or residential housing by local governments. (5) the lack of any comprehensive state wetland protection for inland wellands, and (6) many inland wetlands do not meel specific requirements for Federal jurisdiction under Section 404 of the Clean Water Act of 1977. Recent wetland losses have been particularly heavy in this part of the state. In the recent past. Morris County may have lost about $25 \%$ of its wellands. while over hall of Passaic County's wetlands may have been destroyed. Pressure to develop remaining wellands continues to be intense as demonstrated by proposals to fill all or parts of inland werlands, e.g., Lee Meadows, Bog and Vly Meadow's. Long Meadows and Black Meadow's.

A bill to strengthen protection for these and other inland wetlands has been recently introduced into the New Jersey legislature. If passed, local governments will have some of the necessary tools to provide wise slewardship of these valuable natural resources. The U.S. Army Corps of Engineers is considering wetland acquisition in the Passaic River Basin as an option to prevent flood damages from escalating in the future. This approach was successfully used by the Corps in the Charles River Basin in Massachusetts. Similar initiatives are needed in other states to reduce loss of inland wetlands to urbanization and industrial development. Moreover. Federal regulation under the Clean Water $\mathrm{Act}$ is also vital to profecting these wetlands.

\section{References}

Anderson. B.W.. A. Higgins, and R.D. Ohmant. 1977. Avian use of salicedar communities in the Lower Colorado River Valley In: R.R. Johnson and D.A. Jones (editors). Importance, Preservation and Management of Riparian Habitat. A Symposium U.S.D.A Forest Service Gen Tech. Rep. RM-43. pp. 128-136.

Barber. R.T.. W.W. Kirby-Smith, and P.E. Parsley. 1978. Wetland alterations agriculture. In: P.E. Greeson, et al. Wetland Functions and Values: The State of our Understanding. Amer Water Res. Assoc, pp. 642-651.

Barclay, J.G. 1978. The effects of channelization on riparian vegetatıon and wildlife in south central Oklahoma. In: R.R. Johnson and J F. McCormick (editors). Strategıes for Protection and Managenent of Floodplain Wetlands and other Riparian Ecosystems. U.S D.A. Forest Service. Gen. Tech. Rep. WO-12. pp. 129-138.

Barclay. J.G. 1980. Impact of Stream Alteratıons on Riparian Conmunities in Southcentral Oklahoma. U.S. Fish and W'ildlife Service. FWS/OBS-80/17.9I pp.

Bellrose, F C. 1976. Ducks. Geese and Swans of North America. Stackpole Books. Harrisburg. Pennsylvanid. 5.4 pp.

Boesch. D.F.. D. Levin, D. Nummedal, and K. Boules 1983. Subsidence in Coastal Louisiana: Causes, Rates, and Effects on Wetlands. U.S. Fish and Wildife Service. FWS OBS-83/26, $30 \mathrm{pp}$.

Brinson. M.M., B.L. Suift. R C. Plantico, and J.S. Barclay. 1981. Riparian Ecosystems: Their Ecology and Status. U.S. Fish and Wildlife Service. FWS/OBS-81/17. 154 pp.
Brshop, R. A 1481 lous s wetlands. Proc. Iowal Acad Sci 8811111. 16.

Crayg. N.J.. R.E Tumer and J W Day, Jr. I 480 . Wetland lossen and ther consequences in coastal Loustand. Z. Geomorph N F. Suppl Bd 34: 225-241

DeLaune, R.D. R.H. Baumann and J G Gosselink. 1983. Relationships among vertical accretion. coiastal submergence. und erouion in a Louisiana Gulf Coast marsh. J Sed Petroligy 53(1): 147-157.

Dennts, N B. 1980) Coastal regulation and wetlands managenent. citatrons from the California expenence. The Environmental Professional 1: 137.145

Erichson. R.E., R.L. Linder, and K W. Harmon. 1979 Strean channelization (P L. 83-566) increased wetland losses in the Dakouas. Wildl. Soc. Bull 7(2): 71-78

Evans. C.D. and K.E. Black. 1956. Duch Productuon Studes sn the Pranie Potholes of South Dakotia. U.S. Fish and Wildhfe Service Spec. Sci. Rep. - Wildlife No. $32.59 \mathrm{pp}$

Farrar, J 1982. The Rainwater Basın Nebraska's Vanishing Wetlands Nebrasha Game and Parki Commissom. $15 \mathrm{pp}$.

Femigno, F., L. Widjeskog. and S. Toth. 1973. Marsh Destructuon N.J Pittman-Rubertion Report Pro]. W-53-R-1, Jub I-G 20 pp

Flomda Conservatum Foundatun. 1977. Restonng the Kissmmee Riv er may he Flornda's envirunnental armageddon. ENFO New'sletter (W.R. Baradit. Editor). \& pp

Frayer, W E. T J Monahan, D.C. Buwden, and F.A. Graybill. 1983 Status and Trends of Wetlands and Deepwater Habutats in the Conterminous Unted States. 1950s to 1970s. Dept. of Forest and Wond Sciences, Colorado State I niversity. Fe. Coilluns. $32 \mathrm{pp}$

Fruge. D.W. 1982. Effects of wetland deterioration on the tish and wildhfe resources of coastal Louisiana. In: Boesch. D F. (editor). Proceedings of the Conference on Coastal Erosion and Wetland Muditication an Louistana: Causes, Conequences, and Optuns U.S Fish and Wildhte Service. I-WS/OBS-82/59. pp. 99-107.

Gosselınk, J G and R H Batumann 1980. Wetland inventorles: Hetland loss along the United States coast. Z. Geomorph. N.F. Suppl. Bd. 34. 173-187.

Great Lakes River Basin Commissims. 1981 Wetlands. Great Lahes Communicator (June) Vol 11(9).

Haddoch, J.L. and L.W. DeBates. 1969. Report on Draınage Trends in the Prarie Potbole Region of Minnesota, North Dakota and South Dakota. U.S. Fish and Wildlufe Service, Minneapols, Minnesola 8 pp.

Hardisky. M.A. and V. Klemias. 1983. Tidal wetlands natural and human-made changes from 1973 to 1974 in Delawate: mapping techniques and results. Envir. Manage $7(4): 1-6$

Hedgpeth. J.W. 1978. San Francisco Bay: The wetlands besieged. In: Proceedings of the Nituonal Wetland Protection Symposum. U.S. Fish and Wildlife Service. FWS/OBS-78/97. pp 143-152

Jobnson, R.R. and J.F. McCormick (editors). 1978. Strategres for Protection and Mtanagement of Floodplain Wetlands and other Riparian Ecosystems. Proceedings of the Symposium. Decenber II13. 1978. Callaway Gardens, Georgia. U.S.D A. Forest Service. Gen. Tech. Rep. WO-12. 410 pp.

Kentucky Department of Fish and Wildlife Resources. 1983. February 23 letter from C. E. Kays, Commissioner to B. Wilen. U.S. Fish and Wildlife Service. 2 pp.

Krapu, G.L. 1974. Feeding ecology of puntail hens during reproduction. Auk 91: $278-290$.

Illinois Department of Conservation. 1983. February 16 letter from D. Kenny to B. Wilen, U.S. Fish and Wildlife Service.

Louisiana State University. 1983. Exploring the Atchafalaya Delta. Sea Grant Program. Aquanotes 12(2): 1-4.

MacDonald. P.O . W.E. Frayer, and J.K. Clauser. 1979. Documentation. Chronology, and Future Projections of Bottomiand Hardwood Habitat Loss in the Lower Mississippi Alluvial Plain. Vol. I Batsic Repont. U.S Fish and Wildlife Service, Ecological Services, Vicksburg. Mississippi. $133 \mathrm{pp}$.

Marshall, A.R. 1481. Restoring the Florida Everglades. In: R.C. Carey and P.S. Markovitis (editors). Proceedings U.S. Fish and Wildlife Service Workshop on Coastal Ecosystems of the Southeastern United States. FWS/OBS-80/59. pp. 153-160. 
McDonald, C.B., A.N Ash, and E.S. Kane 1983 Pocosins: A Changing Wetland Resmurce. U.S Fish and Wildlite Service. FWS/OBS$83 / 32$. $22 \mathrm{pp}$.

McGill, R.R., Jr. 1975. Land Use Changes in the Sucramento Raver Riparian Zone, Redding to Colusa Calıt. Dept of Willer Resources, Northern District. $23 \mathrm{pP}$

McGill. R.R., Jr 1979. Land Use Change an the Sattramento River Ripanan Zone, Redding to Colusa, an Update - 1972 to 1977 Calif. Dept of Water Resources, Northern Distract. 34 pp.

McNatt, R. M., R.J. Hallock, and A W Andersun. 1980. Riparian Hahitat and Instream Flow Studıes: Lower Verde River, Ft McDowell Reservation. Arizona. U.S. Fish and Wildlufe Service, Albuquerque, New Mexico. $52 \mathrm{pp}$.

Michigan Department of Natural Resources. 1982. Michıgan' Wet lands. $47 \mathrm{pp}$

Monschem, T.D. 1981. Values of pocosins to game and tish species in North Carolına. In. C.J Richardson (editor). Pocossn Wetlands Hutchinson Ross Publishıng Co., Strondsburg, Pennsylvania. pp $155-170$

National Marine Fisheries Service. 1983. Unpublished coastal wetland (national and southeast) estimates. $3 \mathrm{pp}$.

Nebraska Game and Parks Commussion. 1972. Survey of Habitat Work Plan K-71. Ptttman-Robertson Project W-15-R-28. 78 pp

Nierıng, W. A. 1982. Statement before the House Committee on Merchant Marne and Fishenes (August J0).

O'Connor and O.W. Terry. 1972. The Marne Wellands of Nassau and Suffolk Counties. New York. Marine Sciences Research Center, State University of New York. Stony Brook. 99 pp.

Ohmar, R.D., W.O Deason, and C. Burke. 1973. A riparıan case history: the Colorado River. In: R.R. Johnson and D A. Jones (editors). Importance, Preservation and Management of Riparian Habitat: A Symposium. U.S D.A. Forest Service. Gen. Tech. Rep. RM-43. pp. 35-47.

Orth, R. J and K.A. Moore. 1981. Submerged aquatic vegetation of the Chesapeake Bay: past, present, and future. Transactions of the thith North Amer. Wildl. and Nat. Resources Conf pp. 271-283.

Perry, M.C. R.E. Munroe, and G.M. Haramis. 1981 Twenty-tive year trends in diving duck populatıons in Chesapeake Bay. Transactions of the 46th North Amer. Wild and Nat. Resources. Conf. pp. 299-309.

Redelfs, A E. 1980. Wetlands Values and Losses in the Unted States M.S Thesis. Oklahoma State Univ., Stillwater. $143 \mathrm{pp}$.

Roe, H.B. and Q.C. Ayres. 1954 Engıneering for Agricultural Draınage. MeGraw-Hill Book Co., New York. 501 pp.

Richardson, C.J 1981. Pocosins: ecosystem processes and the intluence of man on system response. In: C.J Richardson (editor). Pocosin Wetlands. Hutchinson Ross Publishing Co., Stroudshurg, Pennsylvania. pp. 135-151

Richardson, C.J., R. Evans, and D. Carr. 1981. Pocosins: an ecosystem in transition. In: C.J. Richardson (editor). Pocosin Wetlands. Hutchınson Ross Publıshing Co., Stroudshurg, Pennsylvania. pp. 3-19.

Shaw, S.P. and C.G. Fredine. 1956. Wetlands of the United States. Their Extent and Their Value to Waterfowl and Other Wildlife. U.S. Fish and Wildlife Service. Circular 39.67 pp.

Sidle, J.G. 1983. Wetland dramage and the James River. North Dakota Outdoors (August): 10-14

Smith. A.G., J.H. Stoudt, and J. B Gollop. 1964 Prairie potholes and marshes. In: J.P. Linduska (editor). Waterfowl Tomorrow. U.S. Fish and Wildlife Service, Washington. D.C. pp. 39-50

Stevenson, J.C and N. M. Confer. 1978. Summary of Available Information on Chesapeake Bay Submerged Vegetation. U.S. Fish and Wildife Service. FWS/OBS-78/66. $335 \mathrm{pp}$.

Stevenson, J.C.. N. Confer and C.B. Pteper. 1979. The Decline of Submerged Aquatic Plants in Chesapeake Bay. U.S. Fish and Wildlife Service. FWS/OBS-79/24, 12 pp.

Street. M.W. and J.D. McClees. 1981. North Carolina's coastal fishing industry and the influence of coastal alterations. In: C. J. Richardson (editor). Pocosin Wetlands. Hutchinson Ross Publishıng Co.. Stroudsburg. Pennsylvania. pp. 238-251

Swanson, G.A., M.I. Meyer and J.R. Serie. 1974. Feeding ecology of breeding blue-winged teal. J. Wildl. Manage. 38: 396-407.
Thomas, J W , C. Maser, and J E. Rodick. 1979 Wildhife Habitalt in Managed Rangelands - the Great Bastn of Southeastern Oregon. Riparian Zones. U.S.D.A Forest Service. Gen Tech. Rep IPNIV 80. $18 \mathrm{pp}$

Thompson, R. 1983. Ameriea's Disappearing Wetlands. Congresumal Quanterly Inc. Editorial Research Reports (August 19). 61,5-6,31

Todd, R. 1978. Where to find Anzona's hirds. Arizona Wildlıfe V'ieus 21(12): 6 .

Tumer, R.E. 1979. Louisiana's coastal tishenes and changng environmental conditions. In: J.W. Day, Jr., D. D. Culley, Jr. R.E. Tumer, and A.J. Mumphrey, Jr. (editors). Proceedings of the Third Coastal Marsh and Estuary Management Symposium. March 6-7. 1978. Louisiana State University. pp. 363-370

Turner, R. E. and N.J. Craig. 1980. Recent areal changes in Louisiana's forested wetland habitat. Proc of the Louisiana Acad Sci. Vol. XL III: $61-68$

Tumer, R.E. and J.G. Gosselink. 1975. A note on standing crops of Spartina alterniflora in Texas and Florida Contr. Mur. Sci. 19: 113118.

University of Mınnesota, Center for Urban and Regtonal Affarrs 1981 Thematic Maps: Presettlement Wetland of Mimesota and Available Wetlands for Bioenergy Purposes. Prepared for Minnesota Energy Agency

U.S. Army Corps of Engmeers. 1979 Passaie River Basin Study. Plan of Study. New York District. $240 \mathrm{pp}$

U.S. District Court for the District of Columbia. 1983. National Wildlife Federation, et al. v. John O. Marsh, Jr. , et al. Civil No. 9823632. Settlement Agreement

U.S. District Court for the Eastern District of North Carolina, Raleigh Division, 1983. National Wildlife Federation, et al. v. Colonel Wayne A. Hanson, et al. Civil Aetion No. 83-1288-CIV-5.

U.S. District Court for the Western Distnct of Louisiana. 1978. The Avoyelles Sportsmen's Leagne, et al. v. Clifford L. Alexander, at al. Civil Action No. 78-1428

U.S. District Court for the Westem Distnet of Lousiana. 1979. The Avoyelles Sportsmen's League, ct al. v. Clifford L. Alexander, et al. 473 F. Supp. 575. II ELR 20315

U.S. Fifth Circuit Court of Appeals. 1983. The Avoyelles Sportsmen's League, et al v. Clifford L. Alexander, et al. 13 ELR $209+2$

U.S. Fish and Wildlife Service. 1975. Task Force Report on Effects of Road Construction on Wetland Wildlife Habitat. Twin Citıes, Mınnesota. $14 \mathrm{pp}$.

U.S. Fish and Wildife Service. 1977. Concept Plan for Waterfowl Wintering Hahtat Preservation. Central Valley California. Region 1. Portland, Oregon. $116 \mathrm{pp}$. + appendices

U.S. Fish and Wildlite Serviee. 1981. The Platte River Ecology Study Northern Prairie Wildlife Res. Cir. Spec. Res. Rep. 187 pp.

U.S. Fish and Wildlife Service. 1982. Agricultural resources and wetland changes 1972-1980, Palm Beach County, Florida. Natıonal Wetlands Inventory, St Petershurg, Florida. Unpublished mineo $8 \mathrm{pp}$.

U.S. Fish and Wildlife Service. 1984. Report of the Waterfowl Habitat Strategy Team (Draft).

U.S. Fish and Wildlife Service and California Department of Fish and Game. 1979. Protection and Restoration of San Francisco Bay Fish and Wildlife Habitat. 23 pp. + maps

Wauer, R.H. 1977. Signifieance of Rio Grande riparian systems upon the avifauna. In: R.R. Johnson and D.A. Jones (editors). Importance, Preservation and Management of Riparian Habitat: A Symposium. U.S.D.A. Forest Service. Gen. Tech. Rep. RM-43 pp. 165. 174

Weeks, J.L. 1974. Ohio Wetland Inventory. Ohio Dept of Nut. Res. Div. of Wildlife. Federal Aid Project W-104-R-16.

Weller, M. W. 1981. Freshwater Marshes: Ecology and Wildlife Management. Univ. of Minnesota Press. $146 \mathrm{pp}$.

Wisconsin Department of Natural Resources. 1976. Wetland Use in Wisconsin. Historical Perspective and Present Picture. Division of Environmental Standards, Water Quality Plannıng Secton. 48 pp.

Yates, S. 1981. Florida's broken rain machine. The Amicus Journa (Fall): $48-55$

Zinn, J.A and C. Copeland. 1982. Wetland Management. Environment and Naturat Resources Policy Division, Congressonal Research Service, Library of Congress. Serial No. 97-11. 149 pp 


\section{THE FUTURE OF AMERICA'S WETLANDS}

White predicting the future of the Nation's wetlands is extremely difficult and complex, an examination of recent trends in population, agriculture, and wetland protection provides insight into what can be expected. Population growth and distribution and agricultural development greatly affect land-use patterns which impact wetlands. Government's wetland protection efforts are key to preserving wetland functions and values for today's public and for future generations.

The U.S. population is growing by 1.7 million each year. In 1976, nearly $53 \%$ of Americans lived within 50 miles of a major coast. Population density in the coastal zone was 6 times that of the rest of the country (Council of Environmental Quality 1981). Pressures to develop estuarine and palustrine wetlands in coastal areas will remain intense, despite the existence of laws to protect estuarine wetlands. As adjacent upland becomes developed, public managers witl be greatly challenged to protect wetlands from future development.

A recent population shift from industrialized Northeastern and North-Central states to the sunbelt states of the Southeast and Southwest will increase urban and industrial development pressures on wetlands in these latter regions. This new growth will also heighten competition for water between agricultural and non-agricultural users. with tish and wildlife probably being the biggest losers.

Since 1970. non-metropolitan areas have grown faster than metropolitan areas. Suburban counties have grown most rapidly, threatening remaining wetlands with urban development. Since most states do not have wetland protection laws. Federal regulation through the Clean Water $\mathrm{Act}$ is the key means to protecting these wetlands.

Increases in the world's population are likely to continue to have significant impacts on America's wetlands through agriculture. In the $1970^{\circ}$ s. U.S. export of grains and soybeans accelerated to help meet the worldwide rise in demand for food. This increased demand for U.S. farm products reversed a 40 year trend of declining cropland use (National Research Councit 1982). It also led to conversion of vast acreages of bottonland forested wetlands 10 cropland, especially in the Mississippi Alluvial Plain. Increased demand for U.S. food will add more pressure to drain wetlands. Without adequate regulations, many palustrine wetlands will be converted to cropland in the near future.

Other recent agricultural trends likely to increase wetland conversion include:

1. Increasing costs of production and declining net returns per unit of product force farmers to increase production.

2. Conversion of prime agricultural land to non-agricultural uses (e.g., urban) will lead to conversion of rangeland, pasture and wetlands to cropland.

3. Increasing irrigation will tower water tables and dry up wetlands, especially in the West.

Agriculture will also continue to play a major role in degrading water quality, fish and wildlife habitat, and the quality of wetlands, unless improved management techniques are employed. About $68 \%$ of water pollution in the U.S. is caused by agriculture, with soil erosion from cropland being the single greatest contributor to stream sediment (National Research Council 1982). Belore considering conversion of wetlands and other lands to agricultural uses, improved soil management practices should be employed on existing farmland.

Wetland protection in the U.S. currently is accomplished by two primary techniques: 1) acquisition of priority wetlands and 2) regulation of wetland uses. Both Federal and state governments are involved to varying degrees in wetland acquisition and regulation. The use of tax incentives to encourage preservation of wetlands by landowners, although not widely used to date, represents a potentially valuable tool for protecting wetlands. The removal of government subsidies which encourage wetland destruction would also benefit wetlands greatly.

Acquisition of wetlands to preserve fish and wildlife values is ongoing at both Federal and state levels. The two key Federal programs are the Service's National Wildlife Refuge System and the Soil Conservation Service's Water Bank Program. The Service's acquisition efforts focus on wetlands important to migratory birds, especially waterfowl breeding and overwintering grounds. Wetlands are protected by direct purchase or by acquiring conservation easements which prevent wetlands from being drained, burned, leveled, or filled (Figure 49). The Migratory Bird Conservation Act of 1929. the Migratory Bird Hunting and Conservation Stamp Act of 1934, and the Land and Water Conservation Fund Act provide the authority and/or funds to purchase wetlands. The Alaska Native Claims Settlement Act set aside vast wetland acreages in Ataska as National Wildlife Refuges. The Service presently controls nearly 32 million acres of palustrine wetlands and about 2 million acres of estuarine wetlands. Most of this acreage (28 million palustrine acres and I million estuarine acres) is in Alaska. The Soil Conservation Service's Water Bank Program also emphasizes waterfowl habitat acquisition. Through this program, participating landowners receive annual payments over a 10 -year period for preserving wetlands for waterfowl nesting and breeding. State fish and game agencies are also active in wetland acquisition as part of fish and wildlife management areas. Acquisition, although especially useful for preserving priority wetlands of a particular value, cannot be expected to provide protection for all of the Nation's important wetlands. Wetland regulations at the Federal and state levels are vital to preserving America's wetlands and saving the public values they provide. 


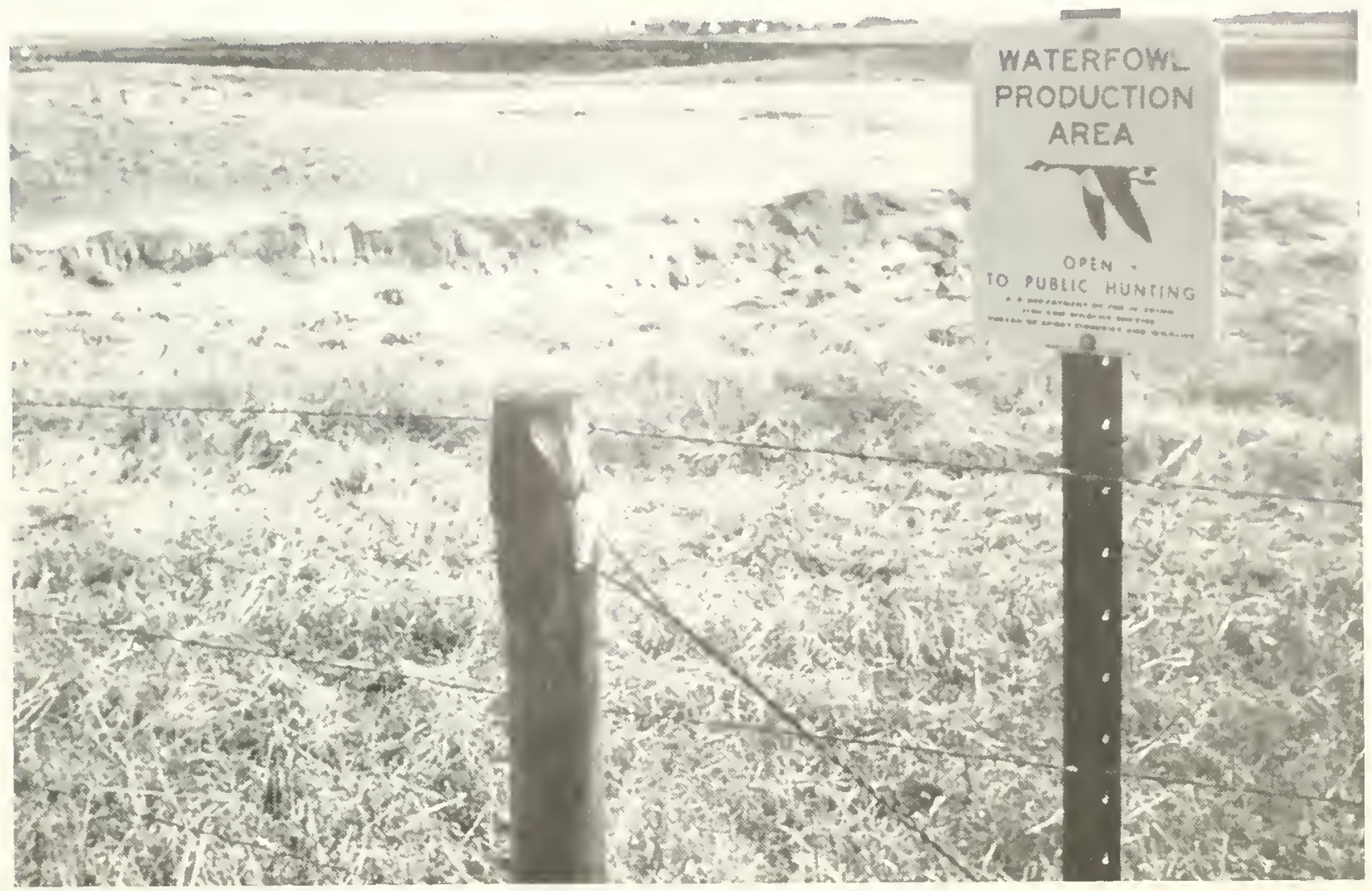

Fig. 49. Establishing waterfowl production areas is one way that the Service protects important waterfowl breeding habilat.

The foundation of Federal wetland regulations is Section 10 of the River and Harbor Act of 1899 and Section 404 of the Clean Water Act of 1977, while twenty-four states have passed laws to regulate wetiand uses. Federal permits for many types of construction in wetlands are required from the U.S. Army Corps of Engineers, although normal agricultural and silvicultural activities are exempt from permit requirements. The Service plays an active role in the permit process by reviewing permit applications and making recommendations based on environmental considerations, under authority of the Fish and Wildlife Coordination Act. The 1982 changes in the Corps regulations reduced the Federal government's role in protecting wetlands and generated much controversy and debate both within and outside of the government. Numerous lawsuits were filed against the Corps by concerned environmental groups over these changes. Under a recent out-of-court settlement (National Wildlife Federation v. Marsh), the Corps will propose new regulations requiring closer Federal and state review of proposals to fill wetlands. This agreement should broaden Federal protection of wetlands. Meanwhile, nearly half of the 50 states have laws in place which regulate wetland uses to varying degrees (Figure 50). Most of these states protect estuarine wetlands, with palustrine wetlands being largely unprotected. For these latter wetlands, Federal regulation is the principal means of protection. Unless these regulations are strengthened, extensive wetland acreages will be destroyed before the end of this century. Agriculture will continue to convert wetlands to cropland in the Mississippi Alluvial Plain. Prairie Pothole Region, South Florida, Nebraska's Sandhills and Rainwater Basin, California's Central Valley and other areas. Urban development of wetlands will continue around urban centers throughout the country. Even if direct losses are controlled, the problem of degrading quality of wetlands must be addressed by government agencies to maintain the biological integrity of these valuable natural resources. 


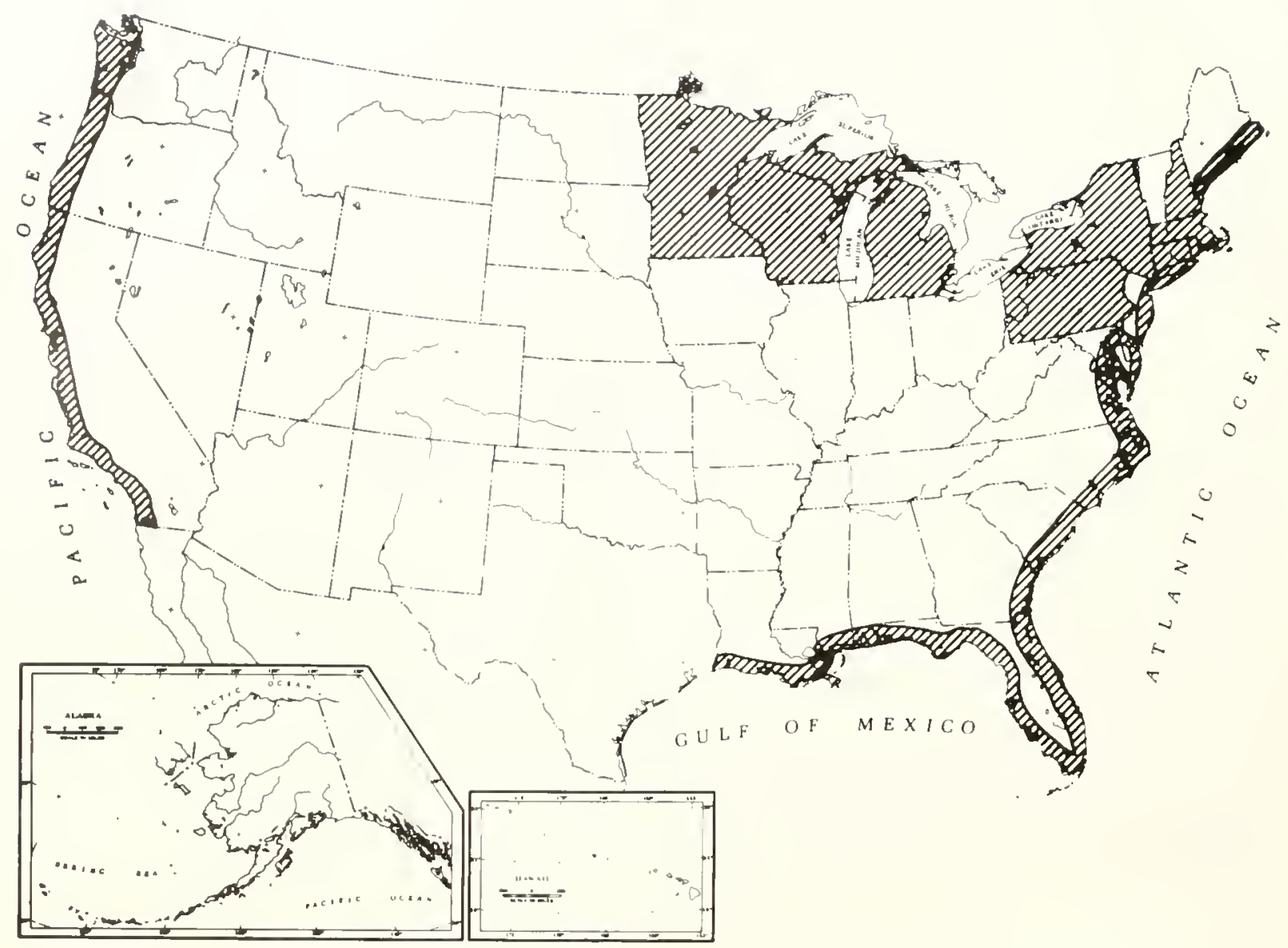

Fig.50. Current status of state wetland protection efforts. Shaded states have enacted laws to regulate wetland uses. Stales with only coastal wetland laws are shaded along their coastlines.

\section{Management Recommendations}

In an effort to halt or slow wetland losses and to enhance the quality of the remaining wetlands, many opportunities are available to both government agencies and the private sector. Their efforts will determine the future course of the Nation's wetlands. The Environmental Law Institute"s publication "Our National Wetland Heritage" discusses in detail public and private means of protecting wetlands (Kusler 1983). Major options have been outlined below.

Government Options:

1. Develop a consistent national policy to protect wetlands of national significance.

2. Strengthen Federal, state and local wetlands protection.

3. Ensure proper implementation of existing laws and policies through adequate staffing, surveillance and enforcement.

4. Remove government subsidies which encourage wetland drainage.
5. Provide tax and other incentives to private landowners and industry to encourage wetland preservation and remove existing tax benefits which encourage wetland destruction.

6. Increase wetland acquisition in selected areas.

7. Improve wetland management on Federal and state-owned lands, including rangelands and forests.

8. Scrutinize cost-benefit analyses and justifications for flood control projects that involve channelization of wetlands and watercourses.

9. Increase the number of marsh creation and restoration projects, especially to mitigate for unavoidable wetland losses by governmentsponsored water resources projects.

10. Complete the National Wetlands Inventory, monitor wetland changes and periodically update these results in problem areas.

11. Increase public awareness of wetland values and the status of wetlands through various media. 
12. Conduct research to increase our knowledge of wetland values and to identify ways of uning wetlands that are least disruptive to their ecology.

Private Options:

1. Rather than drain or fill wetlands, seek compatible uses of those areas, e.g. . timber harvest, waterfowl production. fur harvest. hay and forage. wild rice, hunting leases, etc.

2. Donate wetlands or funds to purchase wetlands to private and public conservation agencies for tax purposes.

3. Maintain wetlands as open space.

4. Work in concert with government agencies to educate the public on wetland values, etc.: private industry's expertise in marketing/advertising is particularly valuable.

5. Construct ponds in upland areas and manage for wetland and aquatic species.

6. Purchase Federal and state duck stamps to support wetland acquisition.

Many of our current wetland problems have national and multi-state implications. For example, wetland drainage in one state may increase llood damages in another state. Cooperation between Federal, state and local gosernments is imperative to solving these problems. Opportunities also exist for the privite sector to join with government in protecting wetlands. Large and small landowners can also contribute to this effort by managing their lands in ways that minimize wetland alterations.

With over half of the wetlands in the conterminous U.S. already lost, it is imperative that appropriate steps be taken to protect our remaining wetlands. Wetland protection demands both public and private sector conperation and action to ensure that Americans will continue to receive the many public benefits that wetlands provide.

\section{References}

Council of Environmental Quality. 1981. Environmental Trends. U.S Gov't Printing Office, Washıngton. D C. $346 \mathrm{pp}$.

Kusler, J. A 1978. Strengthening State Wetland Regulations. U.S Fish and Wildlife Service. FWS OBS-78 98. $147 \mathrm{pp}$.

Kúsiler, J. A. 1983. Our National Wetland Heritage. A Protection Gutdebook. Environmental Law Invitute. Washington. D.C. 167 pp.

National Research Council. 1982. Impacts of Emerging Agricultural Trends on Fish and Wildlife Habitat. Nattonal Academy Press. Washington, D C. $303 \mathrm{pp}$

U.S. District Court for the District of Columbia. 1984 Nutronal Wild life Federation, et al. v. John O. Marsh Jr. et al. Civil No, 82-36,32 Settlement Agreement. 


\section{APPENDIX A Glossary of Common and Scientific Names of Wetland Plants}

Common Name
Alkaligrass
Alders
Arrowheads
Ashes
Asters
Atlantic White Cedar
Bald Cypress
Balsam Fir
Balsam Poplar
Baltic Rush
Beech
Beggar's-ticks
Big Cordgrass
Black Grass
Black Gum
Black Mangrove
Black Needlerush
Black Spruce
Black Walnut
Black Willow
Bluegrass
Bog Laurel
Bog Rosemary
Box Elder
Bulrushes
Burreeds
Buttonbush
California Cordgrass
Cotton Grasses
Cottonwood
Cranberry
Dogwoods
Eelgrass
Elm
Eurasian Milfoil
False Aster
Fetterbush
Giant Cutgrass
Glassworts
Green Ash
Hairgrass
Hardstem Bulrush
High-tide Bush
Inkberry
Jaumea
Labrador Tea
Larch
Laurel Oak
Leatherleaf
Loblolly Baly

Scientific Name

Puccinellia spp.

Almus spp.

Sagittaria spp.

Fraxinus spp.

Aster spp.

Chamaccyaris thoides

Taxodium distichum

Abies balsamea

Populus balsamifera

Juncus balticus

Fagus grandifolia

Bidens spp.

Spartina cynosuroides

Juncus gerardi

Nyssa sy/vatica

Avicennia germinans

Juncus roemerianus

Picea mariana

Jughans nigra

Salix nigra

Poa palustris

Kámia polifolia

Andromeda glaucophytha

Acer negundo

Scirpus spp.

Sparganium spp.

Cephalanthus occidentalis

Spartina foliosa

Eriophorum spp.

Populus fremonii

Vaccinium macrocarpon and $V$. oxicoccos

Cormus spp.

Zostera murina

Ulmus spp.

Myriophy/lum spicatum

Boltonia latisquama

Lyonia hucida

Zizaniopsis miliacea

Salicornia spp.

Fraximus pennsylyanica

Deschampsia caespitosa

Scirpus paluedosus

Ira frutescens

llex glabra

Jaumea carnosa

Ledum groenlandicum

Larix laricina

Quercus lawifolia

Chamaedaphne calyculata

Gordonia lasianthus
Common Name

Loblolly Pine

Lodgepole Pine

Lyngbye's Sedge

Maidencane

Marsh Mallow

Muskgrass

Naiads

Narrow-leaved Cattail

Northern White Cedar

Overcup Oak

Peat Mosses

Pickerelweed

Pignut Hickory

Pin Oak

Pond Pine

Pondweeds

Prairie Cordgrass

Red Alder

Red Bay

Redhead Grass

Red Mangrove

Red Maple

Reed

Reed Canary Grass

Rice Cutgrass

Saltgrass

Saltwort

Salt Hay Cordgrass

Salt Marsh Aster

Sea Myrtle

Sea Ox-eye

Sedges

Silver Maple

Slash Pine

Slender Bulrush

Smartweeds

Smooth Cordgrass

Spikegrass

Spikerushes

Sweet Bay

Sweet Gale

Sweet Gum

Switchgrass

Sycamore

Titi

Tulip Poplar

Water Hickory

Water Oak

Water Tupelo

Waterweed

Wax Myrtle
Scientific Name

Pinus taeda

Pimus contorta

Carex lyngbyei

Panicum hemitomum

Hibiscus moschemos

Chara spp.

Najas spp.

Typha angustifolia

Thuja occidentalis

Quercus hrata

Sphagnum spp.

Pontederia cordata

Carva glabra

Quercus palustris

Pinus serotina

Potamogeton spp.

Spartina pectinata

Almis oregona

Persea horbonia

Potumogeton perfoliatus

Rhizophord mangle

Acer rubrum

Phragmites australis

Phalaris arundinacea

Leersia oryzoides

Distichlis stricta

Batis maritima

Spartina patens

Aster temuifolius

Baccharis halimifolia

Borrichia frutescens

Carex spp.

Acer saccharimum

Pinus elliottii

Scirpus heterochaetus

Polygonum spp.

Spartina alterniflora

Distichlis spicata

Eleocharis spp.

Magnolia virginiana

Mrrica gale

Liquidambar styraciflua

Panicum virgatum

Platamus occidentalis

Cyrilla racemiflora

Liriodendron tulipifera

Carva aquatica

Quercus nigra

Nissa aquatica

Elodea canadensis

Myrica cerifera 
Common Name

Western Hemlock

Western

Widgeongras

Whitetop

Wild Celery

Wild Rice

Willows

Willow Oak

Zenobia
Scientific Name

Tsuga heterephylla

Ruppia occidemalis Scolochloa fesmicacea Vallisneria americana Zizania aquatica Salix spp.

Quercus phellos

Zenobia pulierulenta 




As the Nation's principal conservation agency, the Department of the Interior has responsibility for most of our nationally owned public lands and natural resources. This includes fostering the wisest use of our land and water resources, protecting our fish and wildlife, preserving the environmental and cultural values of our national parks and historical places, and providing for the enjoyment of life through outdoor recreation. The Department assesses our energy and mineral resources and works to assure that their development is in the best interests of all our people. The Department also has a major responsibility for American Indian reservation communities and for people who live in island territories under U.S. administration.
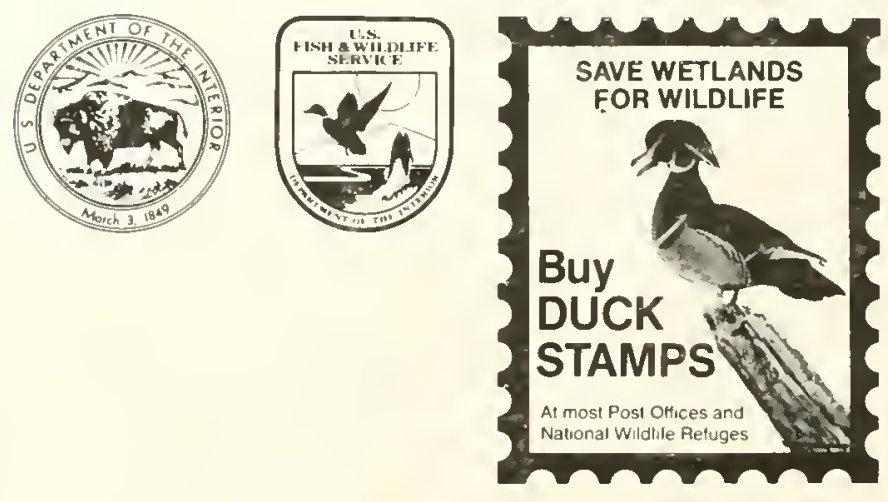

National Wetlands Inventory

Fish and Wildlife Service

U.S. Department of the interior

THIRD CLASS BOOK RATE

Washington, D.C. 20240 